
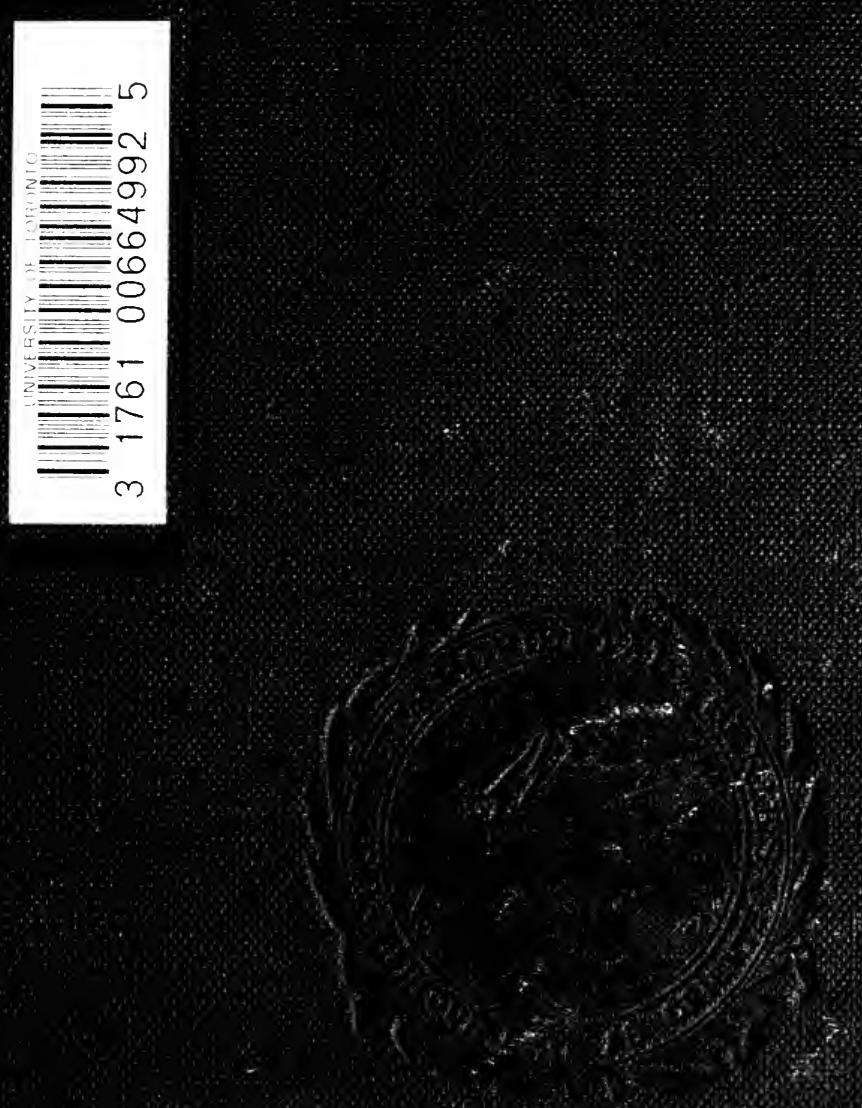

sit
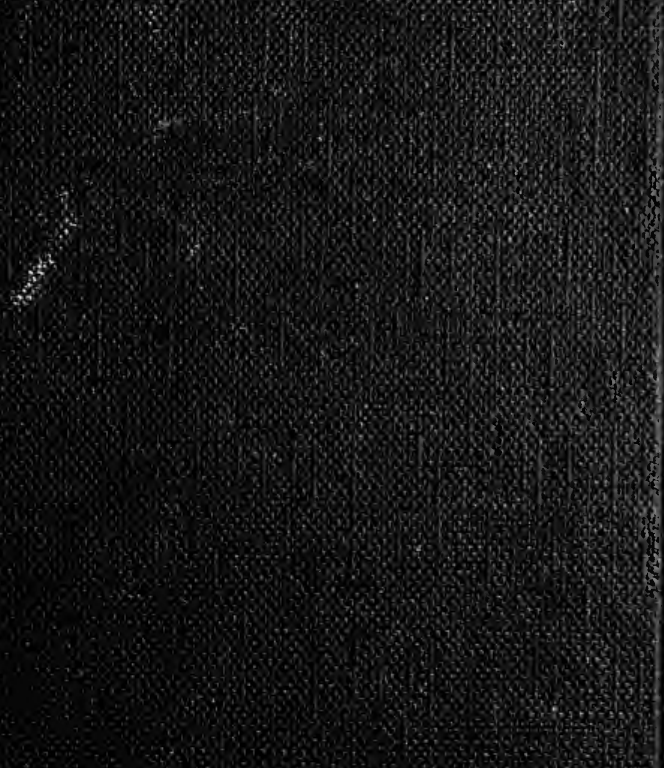


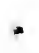



• 


\section{A MANUAL OF BUDDHIST PHILOSOPHY}





\section{A MANUAL OF}

\section{BUDDHIST PHILOSOPHY}

WILliaM MONTGOMERY MigOVERN, Ph.D. (Oxon.),

Lecturer in Japanese and Chinese at the School of Oriental Studies, University of London; Priest of the Nishi Honganji, Kyoto, Japan. Author of Introduction to Mahāyāna Buddhism, Modern Japan, Colloquial Japanese, etc.

\section{VoL. I \\ COSMOLOGY}

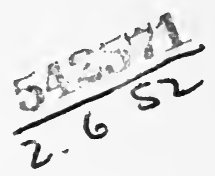

LONDON

KEGAN PAUL, TRENCH, TRUBNER \& CO., LTD. NEW YORK: E. P. DUTTON \& CO. 


$$
\begin{aligned}
& B \\
& 123 \\
& M 3 \\
& V .1
\end{aligned}
$$

$\overline{\text { Printed in Great Britain by Stephen Austin \& Sons, Ltd., Hertford. }}$ 


\section{CONTENTS}

\section{Introduction}

1. The Study of Buddhist Philosophy - 1

2. The Divisions of Buddhist Cosmology - 8

3. The Three Cosmological Schools . . 12

4. Sources of Reference . . . . . 22

Particular Authorities Selected for the Present Work . . . . . 36

\section{Part I}

1. Cosmic Synthesis $\quad$. $\quad$. $\quad$. $\quad$. $\quad$. 39

2. Cosmic Geography . . . . . 48

3. The Divisions óf the Three Dhātus • 60

4. The World of Sentient Beings . . 73

Part II : Cosmic Analysis . . . . . 81

\section{Part III : Cosmic Dynamics}

1. The Nature and Scope of Causality . 163 人

2. The law of Causality Applied to the INDIVIDUAL $. \quad . \quad . \quad . \quad . \quad 169$

AdDitional Remarks on Karma . . 180

The Law of Causality Applied to the

Elements of Existence . . . . 183 メ 


\section{INTRODUCTION}

\section{The Study of Buddhist Philosophy}

A LL forms of Buddhism, however divergent, claim to have A but three objects of worship, viz. the Buddha, the Dharma, and the Sangha. The first is the founder of the faith, the second the teaching which he gave, and the third the order which he founded. Regarding each of the Ratnas or jewels, as they are called, an enormous amount of speculation has grown up, with many different opinions concerning the proper method of interpretation.

Questions concerning the Sangha are largely dealt with in the various versions of the Vinaya Pițaka, or books of Canon law, and their later commentaries. These are concerned with the proper organization of the monasteries, the rites which should accompany the reception of men and women into the order, and the food, clothing, and furniture which should be used by them afterwards. All these questions lie entirely outside the scope of philosophy, and hence outside the scope of our present undertaking.

Speculations concerning the Buddha, or, rather, the Buddhas, together with less elevated beings such as Pratyeka Buddhas and Arhats, have played an even greater part in Buddhist history, for fierce controversies have been waged concerning the nature and powers of each type of Being, and the means by which such rank might be achieved. But as all such problems are more closely associated with religion than with philosophy, they are equally foreign to our present work.

The dharma or law taught by the Buddha to his disciples and thence transmitted to later generations who gradually modified and reinterpreted the older doctrines, was the basis upon which Buddhist philosophy, properly so called, was later erected. Primitive Buddhism was much more a simple 
religious and ethical code than a metaphysical attempt to solve the problems of the universe, but as time elapsed and later commentators, delighting in subtlety, strove to further truth and enhance their own reputations by applying the old formulæ to a rational explanation of the whole universe, the old Dharma was supplemented by a new Abhidharma. Abhidharma is usually called metaphysic, but the first Abhidharma works were but dogmatic treatises, giving a would-be systematic classification of the older doctrinal categories, gradually fitting in others as these came to be formulated.

As yet there was little formal logic or even rational argument from universally accepted data. The basis of truth was considered to be the body of doctrines laid down by an omniscient teacher, and the most that a commentator could do was to give a new and better arrangement to the old dharma-paryāyas, and to bring out the ideas which were considered to be inherent in the older statements. Consequently the old or Canonical Abhidharma is more to be ranked with what we should call theology (save that Buddhism theologized without a thesis) than with philosophy.

Controversy between the various Buddhist sects necessitated the introduction of more abstract reasoning, but appeal could still be made to the sūtras, or, at least, to those sūtras which were held to be sacred by all the schools, so that the most important developments of Buddhist philosophy were made when the Buddhist speculators came into violent conflict with fully developed alien philosophies. This took place, as far as India is concerned, between the first and the fifth centuries A.D., and in China between the fifth and ninth centuries A.D.

Beginning with Buddhaghosa, the Pali school of Buddhism in Ceylon and later in Burma made many important doctrinal additions to the Buddhist lore, but for the most part the Pali school remained sufficiently sheltered to make it predominantly theological rather than philosophical in tone. 
Those who would study Buddhist philosophy must turn their attention to the Abhidharma works, including in that term not only the original Canonical books of such schools as the Sarvāstivādins and Sthaviravādins, but also and more especially the later commentaries, with particular reference to those works in which the Buddhist monks set out to defend their doctrines from outside attack. For the Pali theories we have, of course, to turn to the works of Buddhaghosa and Anuruddha and their followers. For the Hīnayāna ${ }^{1}$ tradition of India proper, we must look to the Sarvāstivādin school, including therein the Mahāvibhāșa, and the works of Vasubandhu and Sanghabhadra. For the Mahāyānists of India we have the great representatives of the two principal Mahāyāna schools, the Mādhyamika and the Yogācārin systems, including Nāgārjuna, Ārya Deva, and Candragomin for the former, and Asanga, Vasubandhu, Dignāga, Dharmapāla, and Dharmakirtti for the latter. The mainsprings of the Chinese Buddhist philosophy are to be found in the writings of the patriarchs of the T'ien T'ai and Hua Yen schools.

Here, however, we meet with great initial difficulty. The Pali texts have indeed come down to us, and the Pali Text Society has rendered, and is rendering, very valuable service in making them accessible to the Western public by means of new editions in the original tongue, and by means of English translation. But the labour of those who would study the more philosophic works of Sanskrit Buddhism is rendered difficult by the fact that most of the important philosophic texts are no longer extant in their original form, for with the destruction of Buddhism in India, much of the literature of Buddhism likewise perished, and though a number of Sūtras, chiefly Mahāyāna, and Avadānas or pious tales have remained, the more serious works have disappeared. From among the numerous Abhidharma works of the

1 For the definition of Hinayāna and Mahāyāna and for the chief points of difference between the two branches of Buddhism see the introduction to my Introduction to Mahāyāna Buddhism. 
Sarvāstivādins, only a single commentary on the Abhidharma Kośa remains. Though we have in the Mādhyamika Vṛtti a fair exposition of the Mádhyamika school, most of the philosophic texts of the Yogācārins have been lost, and what remain are like the Sūtra Alamkāra, devotional handbooks for the aspirant after Buddhahood, rather than textbooks of metaphysics.

Fortunately a certain number of texts were translated into Tibetan, and as years go by, these will probably be revealed to us. But, alas, the Tibetan texts are by no means complete. The Tibetan people, prior to the introduction of Buddhism, were possessed of practically no culture of their own. They were ignorant even of the art of writing, so it is little wonder that when they adopted Buddhism there was a greater demand for Sūtras, Avadānas, Jātakas, and Dhāranīis ${ }^{1}$ than for abstruse works dealing with the minutiæ of ontology and phenomenology. Rather must we be thankful for what has been preserved.

On many points where the Sanskrit remnants are silent, however, and where even the Tibetan Canon can give no help, we find a full explanation in the Chinese translations of the Buddhist works, which are generally though somewhat incorrectly known as the Chinese Buddhist Tripițaka. Here are to be found all the important works of the Sarvāstivādins, Mādhyamikas, and Yogācārins, in addition to the original works of the philosophers of the T'ien T'ai and Hua-yen schools, to whom reference has already been made.

Consequently, he who would make a study of Buddhist philosophy, either of its final systematic form or of the stages of its development, must apply himself to learned treatises on the ultimate nature of the noumenon and phenomena in a language of monosyllables, most of whose characters may be a noun, or a verb, or a preposition, according to the context or the whim of the author or translator.

1 For these and other branches of Buddhist literature see introduction to Burnouf's Bouddhisme Indien. 
Owing to the linguistic difficulties which beset the path, it is no small wonder that in spite of the enormous strides which Oriental scholarship has made in the last few years, much of Buddhist philosophy remains unknown. We may, indeed, claim to know a good deal of the religious side of Buddhism, particularly of the Pali school, for most of its five Nikāyas have found their way into one or other of the European languages. Some five or six well-known Mahāyāna sūtras have also been translated, while of the Vinaya we have at least the more than adequate rendering of the Pali version by Oldenburg and Rhys Davids. Our knowledge of Buddhist philosophy, however, or even of Buddhist theology is confined to three or four translations from the Pali Abhidharma lore, precious as a foretaste of what is to come, but insufficient to satisfy those who seek for a more substantial philosophical diet. Almost nothing has as yet been done to render the Northern philosophical works accessible to the Western reader, and it may be safely said that even the Pali works cannot be fully understood until their tenets are compared with those of the other streams of Buddhist tradition.

The present work is a not altogether successful attempt to further, in an infinitesimal degree, our knowledge of the history of Buddhist philosophy. At the best we can but nibble at the vast storehouse of material before us, and then scurry away into print before the immensity of the subject shall have dawned upon us to such an extent that we are awed into silence.

But if we are to nibble at all, let us at least attempt to do so systematically, and in such a way as will assist further exploration in the future, gnawing indeed but a tiny hole in a giant structure, but a hole which may serve for re-entry both for ourselves and for others. Consequently, instead of trying to cover the whole field of Buddhist philosophy within the limits which, perforce, must be ours, let us single out some one line of inquiry, and attempt to institute a somewhat detailed survey thereof. 
A suitable subject is not difficult to find. Buddhism has all along recognized a distinction between relative and transcendental philosophy, between theories concerning the analysis of phenomena and theories concerning the ultimate nature of things. The first covers much of the ground which in Europe has become the special field of the particular sciences, such as astronomy, physics, chemistry, biology, and psychology, while the latter is more in accord with the Occidental delimitations of philosophy, or metaphysics proper. It is here that we find the kernel of Buddhist philosophy, its would-be solutions of problems touching upon the reality or non-reality of external phenomena, its evaluation of the universe from the standpoint of optimism and pessimism, and all the other eternal insoluble riddles which make philosophy so interesting.

Of these two divisions of the subject matter of Buddhist philosophy, our impulse, naturally, is to choose the latter for our special consideration, and this for several reasons. In the first place there is greater chance for treasure trove, for the Buddhists in common with other Orientals had a better chance to vie with Occidental metaphysicians than with Occidental scientists. The measured and weighty dialectic of the Buddhist sage on the ultimate nature of things is sometimes almost as impressive as the polysyllabic proofs of his Western cousin, but Buddhist astronomy and geology is not even quaint enough to prevent its falsity jarring upon us. It is faintly possible that one out of the many contradictory solutions of noumenal problems offered by the Buddhists may be right if for no other reason than that some philosopher among them seems to have given every possible answer to the problem, but even the wiliest of Orientals would find it difficult to allegorize away the improbabilities of Buddhist physics.

In the second place we should prefer to deal with the transcendental side of Buddhist philosophy, because it is here that Buddhism was most original and escaped furthest 
from the bonds of tradition, Buddhist or Tïrthaka. The reason for this is to be found in the fact that the earlier works gave minute details concerning relative philosophy, and very little about noumenal matters. Consequently, when the great thinkers of Buddhism, such as Vasubandhu, Dignäga, and Dharmapāla, arose, they dared not alter the older myths concerning the size or composition of the sun or moon, but were able to formulate highly interesting views concerning the ultimate nature of any and every form of matter and mind.

For these and many other reasons, then, we should prefer to deal with the transcendental side of Buddhist philosophy. Practical necessity, however, keeps us to the other and less interesting aspect of the subject, in this initial survey, if for no other reason than that Buddhist transcendental philosophy is completely unintelligible without a knowledge of the relative philosophy upon which it is based. Modern Western philosophy is far more comprehensible without a knowledge of Western science than is Buddhist metaphysics without a knowledge of Buddhist pseudo-science. A Buddhist can only discuss the reality of the universe in terms of dharmas, paramānus, caitasikas, citta-viprayukta dharmas, dhātus, āyatanas, and skandhas-and, unless we are acquainted with the implications of these terms, none of which have exact Western equivalents, we shall have studied Buddhist philosophy in vain. The atheism, polytheism, pantheism, and monotheism of the various aspects of Buddhism can only be properly understood when one knows of the devas of the Käma dhātu, and of the Brahmās of the Rūpa dhātu.

Consequently, in order that we may lay the foundations for a later, more serious study of Buddhist philosophy, it is necessary that we flounder among mythical continents and impossible seas. We must seek to solve the problem hotly disputed between the Sarvāstivādins and the Mahāsānghikas, as to whether the lictors of Hell are really sentient beings, or are specially created automata. We must wander through long, dull, and badly arranged lists of states of consciousness, 
and when all this has been accomplished we may claim indeed, not to have become acquainted with Buddhist philosophy, but to have become capable of discussing its problems.

\section{The Divisions of Buddhist Cosmology}

This relative philosophy of Buddhism we have chosen to call Buddhist cosmology, not that the term is particularly appropriate, but because a better is lacking. Thus defined, the subject has three main divisions: (1) Cosmic synthesis; (2) Cosmic analysis ; (3) Cosmic dynamics.

(1) The first covers the myths concerning cosmography, the nature, size, and shape of the phenomenal universe taken as an existing entity and unanalysed. This covers the field of what in the West would be called astronomy and geology, save that the Buddhist astronomer would aspire to Dante's rôle, and explain not only the stars, but also the heavens and the various inhabitants thereof.

This is the point on which Buddhism is least original. Most of its myths were not only borrowed from contemporary Indian thought, but were even part of that primitive cosmography which Warren, in his book on the subject (Paradise Found) sought to explore. Nevertheless, once incorporated in the Buddhist system, it had an important part to play in the moulding of later speculation, as when the commentators drew up their list of states of consciousness upon the threefold division of the universe into Kāma, Rūpa, and Arūpa dhātus.

During the course of our present work, it will be seen that it is upon this mythology that all systems of Buddhism are most agreed, which shows that the main structure of Buddhist cosmography was an integral part of Buddhism at a date prior to its division into variant schools. This gives us a very early date. The embellishments of the later commentators (those of Ceylon may be seen in Spence Hardy's Manual of Buddhism) never succeeded in altering the essential structure.

Here, however, we have to distinguish between $(a)$ cosmo- 
graphy proper or the map of the present material world, with its central mountain rocky rings, oceans, and continents, which are in accord with the myths outside of India; $(b)$ and the development of the Heaven and Hell idea into the various divisions of the three dhātus. This is almost purely Indian in its origin, and as regards the order of the upper layers of the heavens, represents the order of development of thought in India. The fact, for example, that the Devas are placed above the Asuras goes back to the time when the Persians and the Indians were united. The thirty-three gods who inhabit the summit of Mount Meru are a remnant of the theological development of the Vedas. The heavens of Mahābrahmā represent the later Brāhmaṇa and Upanișad struggle after some higher ideal than the Vedic deities. The four Arūpa dhātus are Buddhist attempts to show the inferiority of contemporary ideas concerning the highest bliss as compared with their own Nirvāṇa.

Details concerning the inhabitants of these abodes are largely the work of the ever-ready Buddhist commentators working upon the material already provided. The great age of most of Buddhist cosmology is further shown by the fact that all versions of the Dirgha Āgama contains an account of the cycle of creation and destruction. As far as we know, this doctrine of the never-ending cycle of creation and destruction was only evolved by the Âryan mind after the period of the Vedas, and is therefore comparatively modern. It is certainly pre-Buddhist, however, though the Buddhist acceptance of the doctrine did much to further the central idea.

(2) Cosmic Analysis.-In addition, however, to accepting contemporary myths regarding the geography of the phenomenal universe, the Buddhists made a great forward step in trying to split up this variegated whole into a number of fundamental units, of which all phenomena are but compounds or combinations. This striving to reduce the complex to a small number of simple and uniform ultimates played a very important part in Buddhist philosophy. Though some 
centuries were to elapse before the full and final list of elements could be given, yet the tendency towards cosmic analysis began with the first days of Buddhism, as may be seen from such primitive categories as the five skandhas, twelve āyatanas, and eighteen dhätus. The marked disagreement between the various schools on these factors of existence, apart from these primitive categories, however, shows that cosmic analysis was developed later than cosmic synthesis, and was the result of much careful and reasoned thought. No longer are non-Indian and pre-Brahmanic elements found, and very little indeed seems to have been borrowed from rival systems of thought, except perhaps the atomic theory, so that the Buddhist classification of the elements of existence is an only original even though valueless contribution to human thought. Of even more importance from the philosophical standpoint are the theories which the Buddhists advanced concerning the nature of their own or any other list of the factors of life.

The development of this ultimate-factors-of-life theory was as important to Buddhism as was the discovery of the elements by the modern scientists to the recent philosophers of the West, save that the eighty odd elements of our own science are all material, while the Buddhist elements are mostly mental, since the Buddhists regarded the mind as no less a compound than the body or any inanimate object. Unfortunately, the Buddhists were too busy with religioethical considerations in their enumeration of these elements for their lists to be of much value for the modern psychologist or philosopher, but with some justice it may be claimed that their analysis is quite as acute as that of any other school of Oriental philosophy.

(3) Cosmic Dynamics.-This refers to the causal forces which bring into combination the factors of existence. The development of this theory was an answer to the question as to how the analysed universe became the synthesized universe, as to why a certain number of elements should not 
remain disassociated but combine to form the human personality. According to some thinkers, this combination of the elements to form concrete phenomena might be due to chance, the spontaneous will of the elements themselves, fate or destiny, or the decree of God. To the Buddhists, however, none of these explanations were acceptable, and they strove to show that the formation and dissolution of compounds was due to an endless cycle of fixed causes. In the earlier stages this consideration of causes was largely made from the personal point of view, and had particular reference to the doctrines of Karma and reincarnation taken over by primitive Buddhism from earlier thought. At this point the doctrine of causality was largely of a mythical or religious nature, as may be seen from the numerous Jàtakas and Avādanas, stories showing how the performance of a good deed in a past life brings about a happy rebirth in this. Associated with this side of causal theory is the old rune known as the Pratitya Samutpäda.

But in addition to this more popular conception of causality even the oldest Sūtras show that consideration was given to the philosophical problem of how one thing is caused or conditioned by another, and when the personal aspect of causality came to be overshadowed by the cosmic or universal co-ordination of causes, Buddhism made an important step along the path of philosophic progress. As might be expected, this was one of the later developments of Buddhist thought, and one which was entirely posterior to the time of the Buddha and the early Church; for whereas all branches of Buddhism agree as to the main points of cosmography (cosmic synthesis), and there are certain categories such as skandhas, àyatanas, and dhātus, which are also common to all forms of Buddhism, however much they may disagree upon other points of cosmic analysis, yet the twentyfour pratyayas or types of causal relationship given in the Pali works are different not only in name, but also in philosophic significance from the types of causes and conditions 
enumerated by the North Indian schools. Among all the later philosophers, however, problems concerning the number of causal influences were of such great importance that cosmic dynamics deserves to rank on an equal plane with the other divisions of cosmology.

\section{The Three Cosmological Schools}

We have thus succeeded in laying down the limits and internal divisions of our present undertaking, but it is also necessary to ascertain what aspects of Buddhism are to be included and what are to be excluded from our present survey, for the word "Buddhism" covers every conceivable type of creed, religious and philosophical. Within the ample bosom of the Buddhist order are to be found schools teaching realism, idealism, nihilism, pantheism, and pragmatism, so that before we can begin using the glib formula "Buddhism says", or "Buddhism teaches", it is necessary to state explicitly just what branch of that vast congeries of associated faiths we intend to be implied, by the use of the general title.

For certain branches of Buddhist research it would be necessary to survey almost every sect and sub-sect before we could say that our investigation was complete. But, having limited ourselves to matters touching upon cosmology, we are more fortunate, for only three schools of Buddhism have paid sufficient attention to cosmological matters, or made sufficiently original contributions to the subject, to warrant our careful examination.

The three schools in question are : (1) The Ceylonese school, founded on the Pali tradition, which claims to be the direct descendant of the earliest Buddhist school known as the Sthaviravādins or Theravādins. We are not yet in a position to know how close was the filiation between the true Sthaviravādins and the Ceylonese school, but for the present we have given the Singhalese scholastics the benefit of the doubt (a rather serious doubt) and dub all those who follow the Pali Canon genuine Sthaviravādins. 
(2) The second school is that of the Sarvāstivandins, the learned and philosophical school of Hīnayāna as it developed in India proper, whose canon was probably in some Prakrit originally, but was later transformed into Sanskrit, which henceforth became its canonical language.

(3) The third school is that of the Yogäcārins, who were also frequently known as the Vidyāmātrins, or Vijñānavādins. This differs from the preceding by being Mahāyāna rather than Hīnayāna. Consequently it had an idealistic rather than a realistic interpretation of cosmological problems. Nevertheless, historically, it was closely filiated with the Sarvāstivādin school, and its philosophical and other works were likewise composed in Sanskrit.

The schools which are not of importance for the study of Buddhist cosmology may be summed up in the following way :

(1) Indian Hinnayāna schools other than those representing the Sthaviravādin and Sarvāstivādin tradition. We are told ${ }^{1}$ that there were eighteen principal Hinnayāna sects in India, though no two accounts give quite the same list of names or specific points of difference. Nevertheless, some eight or nine of these were of such considerable influence that remnants of their philosophy have come down to us. From these we may see that practically all of the Hīnayāna sects were concerned to a greater or less extent with cosmological matters, but that only two of them (the Sthaviravādin and Sarvāstivādin) composed an Abhidharma Pițaka or wrote elaborate commentaries on philosophical matters, so that not only are these two the only schools concerning which we have exact information, but they alone seem to have been possessed of a definite and systematic cosmological philosophy as opposed to the general discussion and counter-discussion of the other sects.

(2) Indian Mahāyana schools other than that of the Yogācārins. Tradition ${ }^{2}$ tells us that there were but two main

1 Cf. Points of Controversy for Pali account, Nanjio's 1284, 1285, 1286 for Chinese account, and Rockhill's Life of the Buddha for Tibetan account.

${ }^{2}$ Cf. introduction to Takakusu's translation of I-tsing. 
philosophic systems of Mahāyāna in India, one the early Mādhyamika school, represented by Nāgārjuna and Ārya Deva, and the other the Yogācanin school; represented by Asanga and Vasubandhu. For the present purpose the Mādhyamika school may be completely excluded, for it had nothing whatever to add to cosmological speculation. It was absorbed in disputes concerning the nature of absolute truth and the ultimate nature of reality. From the absolute standpoint the universe was completely non-existent-why, therefore, should one bother to classify the fictitious. From the relative standpoint the Mädhyamika philosophers accepted the Sarvāstivädin categories without altering them in any respect.

An examination of the various Mahāyāna Sūtras and Sāstras rendered into Chinese shows that there were a number of important points of view prevalent among Indian Mahāyānists which found presentation in neither of the two above-mentioned schools, but these may also be neglected, first, because they were never developed in a systematic form, and secondly (and even more important), because such works are more concerned with metaphysical or ontological matters than with problems of cosmology.

(3) Chinese and Japanese schools of Buddhism. For the most part, Buddhist communities founded outside of India were content to derive their fundamental philosophic conceptions from the original Indian schools of thought, though, for this purpose, it may be necessary to count Ceylon, the home of the later Sthaviravädin movement, as part of India. Thus Burma and Siam have accepted their cosmology as well as their ontology from the Pali Abhidharma works. The Tibetan and Mongolian monks when not executing devil dances, or composing incantations and charms, study the philosophical systems of India, adding thereto very little of their own. Chinese and Japanese Buddhism, however, have developed schools of thought which are quite original and important, and any general history of Buddhist philosophy 
must or should give considerable attention to these innovations, more particularly the development of the Indian Buddha Kṣetra cult into philosophical monotheism, and of the Mädhyamika nihilism into realistic pantheism; but these developments had little reference to cosmology, and the new schools were content to accept the cosmic geography evolved by either the Sarvāstivādin or Yogācārin schools. ${ }^{1}$

We have seen, then, that a study of the three schools, Sthaviravādin, Sarvāstivādin, and Yogācārin, is sufficient to make us familiar with the whole field of Buddhist cosmology. In order, however, that the history of the development of cosmological ideas may be understood, it is necessary to say a word concerning the chronology and interrelation of these three schools.

(1) The Sthaviravādins, ${ }^{2}$ or, at least, the school which flourishes in Ceylon, Burma, and Siam, and which lays claim to that title, occupies a curiously isolated position among the various Buddhist schools. Its Sūtra and Vinaya Pițakas are essentially the same as those of the other Hinnayana schools, as may be seen by comparing the Pali versions with the various Hīnayāna Sūtra and Vinaya works contained in the Chinese Buddhist Canon, but its chief claim to philosophical distinction is its Abhidharma Pițaka, which seems to have been brought from Ceylon shortly after the conversion to Buddhism of that island by Mahinda (Mahendra), the son or nephew of Aśoka, in the third century B.c. It is doubtful if the whole of the Pali Pitaka was brought over at this time, or even that the work of composition had been completed at so early a date. In any case, the transmission was oral and subject to interpolation. But the seven Abhidharma works must have existed very much in their

\footnotetext{
${ }^{1}$ Cf. the cosmological sections of the 四教義 for T'ien-t'ai and 五 教 章 for Hua-yen.

2 The general history of Buddhism in Ceylon is too well known to make it necessary to quote authorities ; compare, however, Geiger's translation of Mahāvamsā, and the section on Ceylon (vol. iii, p. $11 \mathrm{ff}$.) in Sir Charles Eliot's new book Hinduism and Buddhism.
} 
present form at the beginning of the Christian era, about which time they were reduced to writing. At this period, although the Canon was kept in Pali, a number of commentaries were written in, or translated into Singhalese, but these have now been lost. Thereafter the most important period of Pali Buddhism, during which this school was almost, though never quite, transformed from a theology into a philosophy, is represented by Buddhaghosa, about A.D. 400 . $\mathrm{He}$ wrote a number of new commentaries (if history can be trusted), destroyed the older commentaries, and came to be considered the official interpreter of the Pali school. After the time of Buddhaghosa, though from a material point of view the Buddhist order experienced many vicissitudes, its philosophical development was very slow and gradual. As the Ceylonese type of Buddhism eventually dominated Burma and Siam, where it seems to have supplanted other forms of Buddhism, the Buddhism of Buddhaghosa is now the predominant form of Hinayāna, and therefore the system of thought best known to the West.

One point, however, deserves attention, and that is the complete absence of all North Indian mention of the Abhidharma books of the Pali Canon. The Pali school makes very sweeping claims for itself. It claims that Pali was the original language of the Buddha, that the seven Abhidharma works are part of his gospel, and that they were recited at the first council. It is also stated that Buddhaghosa, the great commentator, came from somewhere in North India, and was a scholar of some repute before his arrival in Ceylon. Both of these statements imply a close relationship between the Ceylonese Buddhist school and that of India. It is therefore important to point out the following facts: The only Hīnayāna Abhidharma Pițaka which we can prove to be known to the Buddhists of North India was that of the Sarvāstivādins. For a long time it was thought 1 that these

1 See e.g. Kern's Manual of Indian Buddhism, p. 5, n., and Vidyābhūṣana's Indian Logic: Mediaeval School, pp. 63-4. 
works were but different versions of the Pali Abhidharma Canon, or that if different, the Sarvāstivādin works were probably half commentaries or rewritings of the works preserved for us in Ceylon. We now know, however, that there is no connexion between the two sets of works, that the Sarvāstivādin writings were composed by persons whom it is scarcely possible to conceive could have seen the Pali works, or even to have heard of their categories. Nor do we find any scholar either inside or outside the Sarvāstivādin school who accepted, quoted, or even attacked the Pali Abhidharma works. They were completely ignored as far as we have any record, and though the Sthaviravādins were cited from time to time, there is no place where we can identify their quoted statements in such a way as to prove the possession of a definite Abhidharma Canon. Furthermore, there are several places where the Sautrāntikas agree with the Sthaviravādins as opposed to the Sarvāstivādins, but in their arguments with the latter they merely say: "We do not accept the Abhidharma Pitaka, but hold only to the Sūtras" ; but as in these passages the seven works of the Sarvāstivādins are expressly referred to, it is curious that the Sautrāntikas do not mention any rival Abhidharma Pițaka, particularly as the existence of such a rival would have been an argument against accepting any Abhidharma Pițaka.

In the same way whenever the Mādhyamika philosophers refer to the Hīnayāna Abhidharma works, the Sarvāstivādins are the only ones quoted. In fact, among the Mādhyamikas the term Abhidharmika is used as a synonym for Sarvāstivādin.

It is difficult to argue from silence, but in any case it can be seen that the Pali Abhidharma can never have been considered the fountain-head of wisdom among the North Indian Buddhists. It was probably composed in South India, where Buddhist philosophy developed on lines of its own. ${ }^{1}$

1 On the geographical distribution of the Hinnayāna sects see introduction to Takakusu's translation of the travels of I-tsing ( $\mathrm{I}$ ching 義 淨). 
Secondly, as regards Buddhaghosa. He can hardly have been a North Indian, because we know that in North India the Sarvāstivādin influence was particularly strong, and yet in his Attha Salīni he mentions various opinions concerning the Abhidharma Pițaka, but makes no reference to the Sarvāstivādin Abhidharma. Problems concerning the lineage of the Ceylonese school, however, present a special field of research, so that at present we may pause no longer over the matter.

(2) The Sarvästivādins.-Every year the researches of scholars into the recesses of Buddhist history tend to bring out the importance of the part played by the Sarvāstivādins. Tradition states that they became a definite sect about three hundred years after the death of the Buddha, but the Sarvāstivādins themselves claim that three of their works were composed at the time of the Buddha, one about a hundred years thereafter, and the remaining three about three hundred years after his death. One of these last is the famous Jñāna Prasthāna, which was regarded as the most important, in fact the keystone of them all, the other six words being known as the six pāda or feet.

The headquarters of this sect seem to have been in Gandhāra and Kaśmira, which were then, even more than now, integral parts of India. Originally the sacred language of the Sarvāstivādins must have been some form of Prakrit, and the phonetic rendering of certain terms in the earlier Chinese translations would tend to show that the seven Abhidharma works themselves were composed in this style. Later, however, Sanskrit was adopted, and the influence exerted by this school did much to make this language the canonical tongue of Buddhism, though, of course, the Ceylonese retained a language (Pali) which though composite, literary, and artificial, was nearer the original colloquial than Sanskrit. ${ }^{1}$

${ }^{1}$ Incidentally Pãli and Sampskrta are more correct forms, but the customary spelling has of course been retained. 
No doubt the conversion of Kaniska to this school, in the first century A.D., was an influential factor in making the Sarvāstivādins the predominant school over the whole of India, from whence it spread to Central Asia, Java, and China, etc. It seems to have been regarded in India as the Hīnayāna school par excellence, and therefore regarded as the object of refutation on the part of those persons who were not Buddhists, or who, though Buddhists, yet belonged to one of the Mahāyanna schools. Many of the founders of the other Buddhists schools were in fact originally Sarvāstivādins, and bore traces of Sarvāstivādin influence to the end of their days, however much they might differ on points of detail.

The culminating point of the Sarvāstivādin philosophy appears to have been between the first and fifth centuries A.D. At the beginning of this period a number of commentaries appeared bearing the name of Vibhasạa. Probably about the beginning of the second century A.D. all other such works were cast in the shadow by one such Vibhāșa known as the Mahāvibhāșa. This is an encyclopædic exposition of Buddhist philosophy in the form of a commentary on the Jñāna Prasthāna. Tradition says that it was compiled by a council of five hundred Arhats convoked by Kanișka. The time and the "Arhatity" of the compilers may be called into question, but one must pay a word of admiration to the stupendous nature of the work itself. It covers every point of philosophy as that word was understood in Ancient India.

The next and final stage in the development of Sarvāstivādin philosophy is represented by Vasubandhu and his great opponent Sanghabhadra, whose dates are uncertain, though it is best to assign them to the latter part of the fourth century A.D. ${ }^{1}$ Though less synthetic they were more critical and systematic, and they may be said to represent the high-water mark of Sarvāstivādin philosophy.

1 The date assigned to Vasubandhu by Takakusu in his article in $J R A S ., 1905$, has several times been called into question. In the present instance the matter is of little importance. 
After them the influence of the Sarvāstivādins and of all other branches of Hinayāna declined, partly due, perhaps, to the conversion of Vasubandhu to the Mahāyanna fold. In any case no new developments took place, and in due course the Sarvāstivādin school entirely disappeared from India along with all other forms of Buddhism. It survives in those Far Eastern countries where Buddhism still prevails, but chiefly as an object of study. In these countries all monks, irrespective of sectarian difference, commence their scholastic career by undertaking a course of Sarvāstivādin philosophy, chiefly by means of the Vasubandhu's Abhidharma Kośa.

(3) The Yogācārin Sect. ${ }^{1}$-The Yogācārin school presents a very interesting problem to the student of the development of Buddhist philosophy, for not only does it represent the highest point of Mahāyāna philosophy, but it is also an attempt to synthesize the best elements of both Mahāyāna and Hinayāna ideas. One might be led to suppose that the earlier phases of Mahāyāna would be the most like Hīnayāna, but that once having departed from tradition the tendency towards differentiation would become more marked. The facts, however, seem far otherwise, for the Yogācārin school, which was comparatively late, is something of a compromise. Many points on which this assertion is based lie rather within the realm of transcendental than in that of relative philosophy, but the following point deserves attention. The Yogācārins, alone among the Mahāyānists, revert to the cosmological position of all the Hinayāna sects, and hence, as we have already seen, it is the only Mahāyanna school to possess a definite cosmological system. Hīnayāna was largely concerned with points bearing upon phenomenology, the Mādhyamikas and other representatives of early Mahāyāna idealism were concerned with ontology alone. The Yogācārins, after expressing their opinions on matters ontological, reverted to discussion concerning phenomenology. The most

1 The best summary of the traditional account of Yog. history is to be found in the Pa-tsung, vol. ii, p. $9 \mathrm{ff}$. 
important difference between the Hinnayānists, the Mãdhyamikas, and the Yogācanrins is that the first believed in the existence of the external world and its constituent parts, the dharmas; the second completely denied the existence of the world, and the dharmas; while the third believed that the world, though an eject of the mind, has yet a relative existence, and that, in fact, the dharma are but stages of the mind's unfolding.

There is some doubt as to the exact date of the foundation of the Yogācārin philosophy, but its first patriarchs, Asanga and Vasubandhu, ${ }^{1}$ cannot have lived before A.D. 359 nor after A.D. 450. Both Asanga and Vasubandhu, who were brothers, commenced their careers as Hīnayānists, which may partially explain the synthetic nature of the Yogaacāin school. Vasubandhu, the younger brother, in fact rose to great distinction among the Hīnayānists, his Abhidharma Kośa and other Hīnayāna works giving him great renown all over the Buddhist world.

His cautious, sane, and philosophical mind probably prejudiced him against the existing forms of Mahāyāna, which were either wildly superstitious and exaggerated, or else concerned with points of more sophistic nihilism (Mādhyamika). Asanga, however, as we may see from his books, though more than a passable philosopher, was possessed of a more religious frame of mind, and consequently went over at an early age to the more devotional and mystic Mahāyāna, into which, however, he introduced a great number of modifications, and developed the crude idealism found in many of the Sūtras composed after the time of Nāgārjuna into a definite and systematic school of thought. As yet, however, his system was more theological than philosophical, as may be seen from the introduction of the Maitreya myth.

1 For details concerning the lives of Vasubandhu and Asanga see Takakusu's translation of Paramärtha's "Life of Vasubandhu": T'oung Pao, 1904, and also introduction to Lévi's translation of Asanga's Sütrālaìkära. 
The system evolved by Asanga eventually won over Vasubandhu, who at once turned his greater philosophical powers to the development of the new school of thought, and though he died not many years after his conversion, it was not before he had laid the foundations of a philosophical movement which represented the highest phase of Indian thought, and which for consistency, acuteness, logical reasoning, and rational procedure, compares favourably with any philosophical system not based upon data provided by experimental science.

Many names figure in the galaxy of thinkers produced by the Yogācārins, between the death of Vasubandhu and the downfall of Buddhism in India, but of these Dignäga, Dharmapāla, and Dharmakirtti are the most important. Dignāga revolutionized Buddhist logic, and in some ways may be said to be the real founder of Buddhist philosophy as opposed to Buddhist theology, since it was he who first laid down the principle that every doctrine must be proved either by sense-experience or reason without reference to tradition. Dharmapāla carried on the work of Dignāga with more especial reference to metaphysics, and his commentary on Vasubandhu's Vidyāmātra Siddhi became, for the Chinese at least, the standard manual of the Yogācärin sect. Dharmakītti, slightly later, made many notable additions and modifications to the Yogācärin philosophy. Unfortunately, the period of his activity was too late for the Chinese to take much note of him, but the Tibetan Tanjur contains many of his works.

\section{Sources of Reference}

We have already made reference to many of the important writings of each of the three sects in defining their chronological relationship. It would be well, however, to append a more complete list of the works which serve as authoritative sources of information concerning the cosmological (and other) doctrines of each school. 
1. The Sthaviravādins.-Here the scriptural authorities consist of the Pali versions of the Vinaya, Sutra, and Abhidharma Pitakas. Of these the first may, in the present instance, be entirely neglected. The Sütra Pițaka consists, as is well known, of the following five Nikāyas:-

(1) Digha Nikāya, a collection of 34 long dialogues with no particular order. ${ }^{1}$

(2) Majjhima Nikāya, or collection of 150 of middle length, likewise in no systematic order.

These two are probably older than the next two Nikāyas, and embody the older and less formally categorized doctrines.

(3) Samyutta Nikāya, ${ }^{2}$ a collection of a large number of small sutras, in which an attempt has been made to arrange them according to subject, much of the psychological material of early Buddhism, for example, being arranged under the group on Āyatanas.

(4) Ariguttara Nikāya, likewise a collection of a great number of small sutras, arranged according to numerical categories, a favourite method of classification.

These represent the second stage of Buddhist philosophy in which there is no longer a long dialogue leading up to the enunciation of a new truth, but the discussion of the meaning of certain terms arranged in categories. The fifth or Khuddaka Nikāya we can ignore in the present instance. In none of the Pali Nikāyas is there a systematic exposition of any aspect of Buddhist cosmology, but many technical terms are employed here and there which serve as the basis for the later developments. As might be expected, the terms relating to cosmic synthesis are nearly all present, as are also many terms relating to cosmic analysis, but almost none relating to cosmic dynamics.

1 Translated into English by Professor and Mrs. R. Davids, Dialogues of the Buddha, 3 vols., quoted hereafter as D.B.

2 The first portion translated by Mrs. R. Davids, Kindred Sayings. Individual English translations of separate sūtras and French and German translations, partial or complete, need no mention. 
The next stage is represented by the seven works of the Pali Abhidharma Pițaka. These are : (1) Dhamma sañgani ; (2) Vibhañga ; (3) Dhātu Kathā; (4) Puggala-paññatti ; (5) Kathāvatthu; (6) Yamaka; (7) Patțhāna. Of these, especial attention should be paid to :-

(1) Kathāvatthu (Points of Controversy is the title of the English translation, by Mrs. Rhys Davids and Aung), as containing an account of the doctrines concerning which the Pali school differed from the other members of the Hīnayāna community. In certain cases these refer to cosmological matters.

(2) The most systematic treatment of cosmic synthesis is to be found in the Vibhanga (last chapter), though the bulk of the categories in this book, as in the others, refer to cosmic analysis.

(3) For us the most important treatment of cosmic analysis, however, is to be found in the Dhamma Sangani, particularly as we have a translation by Mrs. Rhys Davids. ${ }^{1}$

(4) Pali theories concerning cosmic dynamics are to be found in that vast literary jungle known as the Patțhāna. Though this is regarded as the most important of the seven works, no one in the West has yet fought his way through the thicket. In spite of the enormous amount of repetition which it contains, a translation of this work will throw a great deal of new light on the evolution of Buddhist ideas.

Posterior to the Abhidharma Pitaka proper, but still Indian, or, at least, partially Indian, are such semi-canonical works as the Milinda Pañha, Netti, Pețakopadesa, etc. Of these the first is well known owing to Professor Rhys Davids' translation, known as The Questions of King Milinda.

The next phase of Pali Buddhism, which is in some ways the most important, since it represents the final and complete system of cosmology, is to be found in the works of Buddhaghosa. Out of the vast number of works written by,

1 A Buddhist Manual of Psychological Ethics. 
or at least ascribed to, him, we need mention only the following:-

(1) Visuddhi Magga, the path of purity, an original work, which is, in fact, a very able encyclopædia of Buddhist doctrine, corresponding to, but inferior to, the Sarvāstivādin Abhidharma Kośa by Vasubandhu. The Visuddhi Magga is the standard authority for Neo-Sthaviravādin philosophy.

(2) Sumangala Vilāsinī, a commentary on the Dīgha Nikāya, with an introductory survey of all Sūtra literature.

(3) Attha Sālinī, a commentary on the Dhamma Sangaṇi, with an introductory survey of all Abhidharma literature. Now translated into English by Ting and Mrs. Rhys Davids (The Expositor).

(4) Pañca-ppakarana Atthakathā, a commentary on the last five books of the Abhidharma Pitaka.

Out of the large number of works produced after the time of Buddhaghosa only one calls for special comment. This is Anuruddha's Abhidhammattha-sangaha, a small summary of Buddhist doctrine which has become the handbook of every monkish student of Southern Buddhism, to a large extent replacing the Visuddhi Magga owing to its greater brevity and conciseness. The Aung-Mrs. Rhys Davids' translation of this work ${ }^{1}$ is invaluable not only because of its carefully considered rendering of those terms which are most common in all Buddhist literature, but also because of the introductory essay by Aung, who gives there a most valuable account of the later interpretations of the general field of Sthaviravādin philosophy, which, as we know, was largely concerned with cosmological matters.

2. The Sarvastivādins.-As in the case of the Pali school, we may neglect the Sarvāstivādin Vinaya Piṭaka, and notice only the other two. We now know quite definitely that the

1 Compendium of Philosophy, quoted hereafter as C.P. or Comp. of Phil. 
Sarvāstivādins possessed a Sūtra Piṭaka of their own, which was generally uniform with that of the Sthaviravādins, though differing from it slightly as regards details. Unfortunately, of this we have but fragments, and it would seem that many of the Chinese translations of the four Nikāyas represent sects other than the Sarvāstivādin. Nevertheless, by tracing quotations made by Vasubandhu, Sanghabhadra, and other Sarvāstivādin writers, we see that with one probable exception the present Chinese version was in close agreement with that of the Sarvāstivādins. It may, therefore, be of interest to give their names (restored into Sanskrit) :-

(1) Dïrgha Ágama ${ }^{1}$ (Digha N.), which is generally considered to represent the Dharmagupta school.

(2) Madhyama $\bar{A}$ gama $^{2}$ (Majjhima N.), which is likely a translation of a version belonging to some branch of the Sarvāstivādin school.

(3) Samyukta Ágama ${ }^{3}$ (Samyutta N.).-There are three translations of this work, of which only one is anything like complete. Some give this as belonging to the Sarvāstivādins, others as belonging to the Kāśyapiyas. In any case the arrangement is sadly at fault.

(4) Ekottara Ágama ${ }^{4}$ (Anguttara N.).-This is undoubtedly a rendering of some Mahāsānghika version, as in some parts it is almost Mahāyāna in tone.

There are also a large number of separate translations of individual sūtras within the four Āgamas. These are of great value for the purposes of higher criticism. It may be added here that the order of the sütras is very different from that of the Pali version, that some sütras are to be found only in the Chinese version, and some only in the Pali, and that some sūtras are placed in different Āgamas or Nikāyas,

1 Nanjio's No. 545 (see note on next page). The word Nanjio followed by a number is the number given in Nanjio's Catalogue of the Chinese Buddhist Tripitaka.

2 N. 542.

${ }^{3}$ N. 546, 547, 544, the last alone being complete.

4 N. 543. 
but on the whole there is remarkable similarity between the Northern and Southern version.

One of the very few additions to the Northern Canon is a long sūtra appended to the Dïrgha Āgama, giving a very long and detailed account of the Buddhist cosmorama, or cosmic synthesis. ${ }^{1}$ Doctrinally it differs little from the items scattered through the other sutras of the Chinese translation, and is therefore in agreement with the Pali canon, but none of the sūtras in the Southern version give at any one place so systematic an account. This tendency towards methodology is always more visible in the North than in the South.

The Abhidharma Pitaka of the Sarvāstivādins contains seven works which constitute a definite authoritative canon. Six of these are pāda or props of the seventh or Jñāna Prasthāna, which thus has even a more predominant place among the Sarvāstivādin works than has the Patṭthāna in the Sthaviravādin Abhidharma Pițaka. Like the Pațțhāna, moreover, it was probably the last work to be compiled. As regards the Sarvästivādin Canon, there is evidence to show that in the earlier days, prior to the compilation of the Jñāna Prasthāna, one of the six pāda, called the Dharma skandha, was considered the leading Abhidharma work-a position which it did not readily lose even after the appearance of the Jñāna Prasthāna. The seven works of the Sarvāstivādin Abhidharma Pițaka, together with their traditional dates and authors, are :-

(1) Jñāna Prasthāna. ${ }^{2} 300$ A.B., Kātyāyanīpūtra.

(2) Dharma-skandha pāda. ${ }^{3}$ B.'s lifetime, Mahāmaudgalyāyana.

1 There are three separate translations of this sūtra, N. 549, 550, 551, but I have quoted from 545, since all four versions agree on essentials. This sūtra and other portions of the Chinese version of the long collection is quoted as D.A., while D.N. stands for the Pali version, and D.B. for the English translation of the Pali.

2 N. 1273-5, quoted as Jn. Pr.

3 N. 1296, quoted as Dh. Sk. 
(3) Sañgīti-paryāya pāda..$^{1}$ B.'s lifetime, Sāriputra.

(4) Prajñapti pāda. ${ }^{2}$ B.'s lifetime, Kātyāyana.

(5) Vijñāna-kāya pāda. 100 A.B., Devaśarman.

(6) Prakaraña pāda. ${ }^{4} 300$ A.B., Vasumitra.

(7) Dhātu-kāya pāda. ${ }^{5} 300$ A.B., Vasumitra.

Owing to Takakusu's brief summary of these works in the J.P.T.S., 1905, it is unnecessary to go further into detail concerning their contents.

From the philosophical point of view, however, the seven canonical works are greatly overshadowed by the Mahāvibhāșa. ${ }^{6}$ Here, for the first time, Hīnayāna Buddhists discussed problems in a rational way, and though the older categories survived, an attempt was made to give them a rational foundation. It will undoubtedly prove the most fruitful source for any future work which attempts to give in detail the history of the development of Indian Hinayāna Buddhist thought, since the views of every section of the Sarvāstivādin community are represented. Among the number of different interpretations of the earlier theories as found in the Mahāvibhāṣa we find especial emphasis laid upon the opinions of Vasumitra, Ghosa, Bodhideva, and Dharmatrāta. Each of these four persons wrote a number of independent books, many of which have come down to us in a Chinese translation. A number of other works were composed during this period. These, however, are of less value.

1 N. 1276, quoted (infrequently) as San-par.

2 N. 1317, not quoted, as the translation is questionable.

3 N. 1281, not quoted, as the book is badly arranged and of little value.

- N. 1292, 1277, quoted as Pr. pā. The first part is interesting and valuable.

5 N. 1282, quoted as Dh. K., interesting only because of the singularity of its enumeration and definition of the Caitasikas.

${ }^{6}$ N. 1264,1263 . The latter is the only complete translation, and the only one cited here. Quoted hereafter as M.V. or Mahā. Vibh. For methods of citation see next page. 
Rather more than a hundred and fifty years after the composition of the Mahāvibhāṣa we come to the time of Vasubandhu and Sanghabhadra. This is usually called the Neo-Vibhäșa period. Owing to the great complexity of the Mahāvibhāṣa on the one hand, which makes it of service only as a book of reference, and the lack of completeness on the part of the other works, the documents which must be regarded as the especial manuals for students of the Sarvāstivādin philosophy are the three most important works of this NeoVibhāșa period. These are (1) the Abhidharma Kośa ${ }^{1}$ of Vasubandhu. (There are two Chinese translations, one by Paramārtha and the other by Hsüan Tsang. The latter is considered the more authoritative.) (2) Nyāyānusāra by Sanghabhadra. $^{2}$ This is a commentary on the Abhidharma Kośa, and is at the same time a refutation of those points on which Vasubandhu has departed from the orthodox Sarvāstivādin tradition (Trans. Hsüan Tsang). Abhidharma Prakarana ${ }^{3}$ (the title is questionable). This is a resumé of the preceding work, also composed by the same author. In this case Sanghabhadra has omitted much of his polemic, and contented himself with the mere elucidation of the Sarvāstivādin philosophy.

3. The Yogācārins.-The scriptural authorities for the Yogācārin school consist of six Sūtras and twelve Sāstras. The six sūtras constitute a kind of special Sūtra pițaka, since, in addition to the six sūtras themselves, the Yogācārins vaguely admit the authenticity of all other sūtras, Hinnayāna as well as Mahāyāna. In the same way the twelve Saastras constitute a sort of special Abhidharma Pitaka.

1 N. 1270 (verses only), N. 1269, 1267. Frequently quoted hereafter as A.K., Hsüan Tsang's translation alone being used. In such numbers as $(2-7 a), 2$ refers to the number of the fasc. (卷), the same in all editions ; 7 refers to the number of the sheet, " a " means right side, " $b$ " left side. The pagination of each edition, of course, differs. In this case, as in that of the M.V., N.A., and A.P., I have given that of the edition in my possession brought back from China.
2 N. 1265, quoted as N.A.
3 N. 1266, quoted as A.P. 
As regards the six sūtras, we know that the Yogācārin school founded by Asanga was a new and in many ways original contribution to Buddhist thought. Consequently, it was in exact accord with none of the preceding sūtras even of the Mahāyāna school. Nevertheless, it was found necessary to give the new school added prestige and authority by the citation of certain sūtras which were already known and accepted. Only a small number of sūtras, however, could be used for this purpose. The four Āgamas taught many things contrary to the doctrines of the new school. The same was true of the Prajñā Pāramitā Sūtras and others of a similar type which expounded the theories of the Mādhyamika philosophers. The purely Buddhological sūtras, such as the Sukhāvatì vyūha, were equally inconsistent with the philosophical tendency of the new system. Consequently, recourse could only be had to those sūtras which taught the doctrine of transcendental idealism, a doctrine which seems to have developed subsequent to Nāgārjuna, and in contrast to the latter's absolute nihilism. As finally constituted the new sūtra canon consisted of :-

(1) Abhidharma Sūtra, and Tathāgata-ävirbhāva-gunaalaìkāra Sütra (titles questionable). These were never translated into Chinese, and seem to have been completely lost.

(2) Avatamsaka Sütra, of which we have two complete Chinese translations, ${ }^{1}$ in addition to renderings of separate parts.

Like all the other Sūtras of the Yogācārin Canon, this cannot be earlier than Nāgärjuna, but it must be one of the oldest of the six, as the Tirthakas (heretics) and Hinayānists claim that it was compiled by Nāgārjuna himself, and even the orthodox Mahāyāna tradition has it that he found this sūtra in the dragon's cave. As a whole, however, it is probably later than Nāgārjuna, as, in addition to the doctrine of

1 N. 87-8. 
Sunnya or Nihilism, which we know was the special doctrine of Nāgārjuna, it teaches in a rather vague way the doctrine that the universe is the product of the mind-a later development. Apart from Buddhological ideas, however, it is principally concerned with expounding the stages (fifty-two in all) of a Bodhisattva on his path to perfection or Buddhahood. This sūtra is the basis of a special school of Chinese Buddhism ${ }^{1}$ vaguely related to the Yogācārin school, but with many important differences. The sūtra itself nowhere specifically teaches the Yogācārin doctrine, but it is probably posterior to the Saddharma Pundarika, which, in its present form, is itself posterior to Nāgärjuna.

4. Lankāvatāra ${ }^{2}$ Sütra.-This is a highly important sūtra from the philosophical standpoint, teaching in an almost systematic way a definitely idealistic system, differing, however, on various important points from the later orthodox Yogācārin system, chiefly because the sūtra emphasizes the noumenal aspect of things with a tendency towards monism and transcendentalism, as opposed to the more pluralistic and phenomenalistic idealism of the doctrine of Asanga. Its doctrines are in general accord with the Mahāyāna Śraddhotpāda, of which we have an excellent English translation by Suzuki. ${ }^{3}$

5. Ghana Vyūha. ${ }^{4}$-This sūtra was not translated into Chinese until after the time of Hsüan Tsang, and it is probable that the version which has come down to us has received several new interpolations and additions. In the main, however, its doctrine is in general agreement with that of the preceding sutra, save that the later esotericism is here given greater emphasis.

6. Sandhi Nirmocana Sütra.-Of this we have several Chinese translations, ${ }^{5}$ of which again that of Hsüan Tsang

1 The Hua-yen school mentioned above. The T'ien-t'ai school has for its basic sūtra the Saddharma Puṇdarika.

${ }^{2}$ N. 175, 176, 177. ${ }^{3}$ Awakening of Faith in Mahāyāna Buddhism.

- N. 444 .

5 N. 154, 155, 156, 246, 247. 
is probably the best. The great number of the translations shows how much the work was appreciated in China. This sütra differs from all the others by being a work which really teaches the Yogācārin philosophy in its orthodox form. For this reason it is considered by the Yogācārins as being the most important of the six sūtras. This identity of doctrine early aroused the suspicions even of the uncritical Orientals, and it has been frequently suggested that it was composed by Asanga himself. This view is partially supported by the fact that the sūtra in question is embodied as a whole in the latter's Yogācāra-bhümi, and even more because of the fact that the style is much more like that of a Sāstra than an ordinary Mahāyāna Sūtra (a fact, we may add, that makes it of infinitely greater literary merit).

The twelve Sāstras are :-

1. Yogācāra-bhumi. ${ }^{1}$ - This is the gigantic work in 100 fasc., which is supposed to have been dictated by the Bodhisattva Maitreya, and transcribed by Asanga. Buddhists who were not of the Yogācārin school have not scrupled to credit the whole work to Asanga. Just as the Sandhi Nirmocana is the basic sūtra of this school, so is the Yogācāra-bhūmi the basic sāstra. Later works are largely commentaries or epitomes of this śāstra. In a general way it corresponds in scope to the Sarvāstivādin Mahāvibhāṣa, save that it is written from a single standpoint and its doctrines are given authoritatively, as opposed to the assembled arguments of the diverse thinkers of the Hinayāna school which constitute the bulk of the Mahāvibhāṣa. Consequently, while no Yogācārin work is lacking in philosophic thought, the Yogācāra-bhūmi is more theological than philosophical in tone. Translated into Chinese by Hsüan Tsang. The original lost.

2. Sütra-alaimkāra. ${ }^{2}$-This is a literary epitome of much of the practical side of the Yogācāra-bhūmi, i.e. the stages on the path of the aspirant, and the actions, thoughts, and studies which should accompany each stage, together with the

1 N. 1170, quoted as Y.B. or Yog. Bhu. $\quad{ }^{2}$ N. 1190. 
different resultant meritorious qualities associated with the various degrees of sanctity. It has no connexion with the book of the same title by Aśvaghoṣa. ${ }^{1}$ We are fortunate in possessing French translations of both Asanga's and Aśvaghoșa's Sūtra Alamikāras, the former by the veteran scholar, Sylvain Lévi, and the latter by E. Huber, whose death was a great loss to Buddhist scholarship.

3. Arya-vāca Prakarana, ${ }^{2}$ or the exposition of truth, an early and famous epitome of the metaphysical side of the Yogācāra-bhūmi. There is almost no doctrinal divergence from the original sāstra, and together with the Yogācārabhūmi itself, it is considered to represent the earlier phase of Asanga's thought.

4. Abhidharma Sangīti, ${ }^{3}$ or compendium of philosophy. The verses which serve as the text for each section are ascribed to Asanga, while the prose portion was by Bodhisimha, who must have been an early disciple of the school. Being thus a joint work, a slight development of doctrine is noticeable, as e.g. in the form of the syllogism. Of great importance as showing the intermediate stage in the Yogācārin philosophical development is the commentary on the Abhidharma Sangiti, known as the Abhidharma Samyukta Sangiti, ${ }^{4}$ by Sthitamati, not to be confused with the Sthiramati of the Mãdhyamika school, whose works are also well known.

5. Mahāyāna Samparigraha, or an inclusive treatise on Mahāyāna, of which the verses are by Asanga and the commentary by Vasubandhu. Of this we have three Chinese translations, ${ }^{5}$ of which that by Hsüan Tsang is again considered the most authoritative. Another translation, however, that of Paramārtha, is noteworthy, since a special Chinese sect was founded upon it. ${ }^{6}$ This highly important treatise differs from the preceding as being a commentary on the Abhidharma Sūtra mentioned above, and has no immediate

* 1 N. 1199.

2 N. 1177.

* N. 1178, frequently quoted hereafter as Ab. Sam. San.

5 N. 1183, 1184, 1247.

6 The 攝宗, long since extinct.

$$
\begin{aligned}
& \text { D restoration of the } \\
& \text { titb, but says the } \\
& \text { translation is N.1199, } \\
& \text { and the bhesya, by sthiramati, } \\
& \text { commentator on Trimsike, is } \\
& \text { N.1178, as per n. } 4 \text { here. }
\end{aligned}
$$


connexion with the Yogācāra-bhūmi. It is therefore cast on quite different lines.

6. Yoga-vibhāga, ascribed also to Maitreya. Of this we have no Chinese translation. It was probably a summary of the larger Yogācāra-bhūmi.

7. Daśa-bhümika Śästra. ${ }^{1}$-This is a work by Vasubandhu dealing with the ten stages of a Bodhisattva's career, and incidentally including a discussion of much metaphysical matter. Translated by Bodhiruci. This work, like the Mahāyāna Samparigraha, is of interest, because at one time there existed a special sect in China, ${ }^{2}$ which was based thereon.

8. Madhyānta Vibhāga, the distinction of the mean, the verses ascribed to Maitreya, and the prose to Asanga. This presents the Yogācārin interpretation of the Mādhyamika theory of Sūnya. There are two Chinese translations. ${ }^{3}$

9. Allambana Pratyaya Śāstra.-This is a work dealing with the process and cause of sense impressions. For the meaning of the word Âlambana Pratyaya (which may be roughly rendered Occasional Cause in the Cartesian sense), see the discussion in that part of the present work termed Cosmic Dynamics. The original work is ascribed to Dignāga, the great Yogācārin logician. Of this there are two Chinese translations. ${ }^{4}$ There is also a Chinese translation of a commentary by Dharmapāla, which is even more famous than the original work itself. ${ }^{5}$

10. Pramana Samuccaya.-This is a compendium of Buddhist philosophy, with especial reference to logic. Composed by Dignāga, it was translated by Paramārtha, but it seems to have been lost.

11. Vidyāmātra Siddhi, or exposition of idealism in twenty verses by Vasubandhu, based on the Lankāvatāra Sūtra. This is a simpler and more general work than the following. s. 12 . There are three Chinese translations. ${ }^{6}$

${ }^{1}$ N. 1194. ${ }^{2}$ 地宗, likewise long ago extinct. ${ }^{3}$ N. 1244, 1245, 1248.

4 N. 1172-3. 5 N. $1174 . \quad{ }^{6}$ N. 1238-40.

Bimśatika + trimśika = Vijñaptimätratà siddhi 
12. Last and most important is the Vidyāmätra Siddhi in thirty verses, also by Vasubandhu. ${ }^{1}$ This is a more systematic exposition of the whole Yogācārin philosophy in thirty mnemonic verses. Its vast influence in the Buddhist world is due to the fact that it was made the text for numerous commentaries composed by that galaxy of intellects that followed Vasubandhu. Perhaps the most notable commentary was that written by Dharmapāla. Hsüan Tsang translated this into Chinese and fused with it selections from the commentaries of nine other great scholars, principally Sthitamati and Dignāga. ${ }^{2}$ In their work the theology of the earlier treatises is completely transformed into philosophy, and into philosophy of a very high order.

The importance of this compendium was early recognized, and it became the standard manual for all students of the Yogācārin system. It is still, moreover, considered necessary for the priests of all other schools to have read through it. However one may disagree with its doctrines, it is difficult to overpraise its clear, concise, and logical form of exposition, differing so much from the slovenliness characteristic of a great deal of Buddhist thought. Unfortunately, the scope of the present work enables us to present only its weakest point, viz. the cosmology inherited from earlier tradition. But it is of interest to note that consistent with its principle of accepting only those things which could be proved by reason or experience, the myths which constitute cosmic synthesis found little or no place in it. ${ }^{3}$

1 N. 1215.

2 N. 1197, frequently quoted hereafter as V.M.S.

3 Three other famous and important works of the Yogācārins, which are not included in the list of twelve Śāstras are :-

1. Pañca-skandhaka-śāstra, N. 1176, by Vasubandhu, quoted as Pan. Sk.

2. Pañca-skandha-vaipulya-śästra, N. 1175 , a commentary on the preceding by Sthitamati, quoted as Par. Sk. Vai.

3. Śata-dharma-vidyā-dvāra, N. 1213, by Vasubandhu, quoted as $S$. Dh. These three are short works containing lists of technical terms, with the orthodox interpretations thereof. 


\section{Particular Authorities Selected for the Present WORK}

It has been thought wise to give a more or less complete list of the principal authorities or sources for each of the three schools in question, as it may serve others in conducting more extended research into Buddhist philosophy, more particularly as Nanjio's Catalogue of the Chinese Tripitaka gives no hint as to the order of arrangement, or the chronological philosophical development. Almost each of the above-mentioned works, however, has slight and, in some cases, important points of differentiation, even from other authorities belonging to the same school. Although a study of these variations is of importance for the understanding of lines of doctrinal evolution, in a book of the present size and scope it is impossible to give due emphasis to every phase, and in consequence the principle adopted has been to choose the final phase of each school, and mention briefly the points of difference from the preceding ideas.

The word final needs, perhaps, some explanation. As long as each school continued its corporate existence a certain amount of change or development took place, but within each school a time was reached when the number and order of the categories became fixed. Subsequent development was largely in the nature of reinterpretation of the minor terms and hidden meanings contained in the fixed list of categories. Thus, for example, the early works of each school are by no means in agreement as to the number of the Caitasikas, but after a certain period each school formulated a definite and fixed list (fifty-two for the Sthaviravādins, forty-six for the Sarvāstivādins, and fifty-one for the Yogācārins). Thereafter this number was rigidly adhered to.

For our present purposes, therefore, one work from each of the three schools has been chosen which may be regarded as a representative authority, and which at the same time may be said to mark this final phase. This has been used as the 
standard of interpretation, though constant reference has been made to the other works mentioned above, and some of their important statements quoted, as may be seen more particularly from the foot-notes appended to each page.

For the Sthaviravādin school the standard taken has been the Abhidhammāttha Sangaha, and by way of commentary the notes and introduction to the English translation of this work by S. Z. Aung.

For the Sarvāstivādins the standard taken has been the Abhidharma Kosa, together with the criticisms of Sañghabhadra in his Nyāyānusāra, and Abhidharma Prakarana. Of great value in this connexion have been the classical Chinese commentaries on the Abhidharma Kośa, all of which are to be found in the Su-tsang-ching (Supplementary Canon).

For the Yogācarin school the standard taken has been the Vidyāmātra Siddhi of Dharmapāla, ${ }^{1}$ etc., together with the classical Chinese commentaries, also to be found in the Supplementary Canon. ${ }^{2}$

Whenever reference has been made to these commentaries or to any works other than these-chiefly miscellaneous Chinese works-mention has been made of them in foot-notes. Two works, however, require special attention. These are two Chinese compendiums dealing with Cosmic Synthesis. Here are gathered together all the important references to cosmographic matters in the various Mahāyāna and Hīnayāna Sūtras and Sāstras in the Chinese Canon. Their names are :-

1. 佛䣯 統 紀 Fo-tsu-t'ung-chi, N. 1661. This is a general history of Buddhism, but two sections deal with cosmology.

1 More especially have I used a commentary called 唯儎論証義 Wei-shih-lun-chiang-i, not itself in the Supplementary Canon, but which embodies the important ideas of all the classical commentaries. Quoted as Wei-shih.

2 On many cosmological points where V.M.S. is silent I have quoted from $A b$. Sam. San., mentioned above. The pagination of references to this and other Yog. saastras corresponds to the Kyoto edition of the Tripitaka. 
2. 法界安立圖 Fa-chieh-an-li-t'u. Not in Nanjio or the Tripitaka, but consisting almost entirely of quotations from the Canonical works.

The pagination (in notes) follows the edition in the School of Oriental Studies.

Occasionally I have referred to and quoted from 八宗綱 要 講 義 Pa-tsung-kang-yao-chiang-i.

As Sanskrit is the lingua franca of all Buddhist scholars, in most cases I have restored the Chinese terms to their original Sanskrit form. In certain cases this has been done with the aid of the Mahāvyutpatti, quoted as M.Vy. This is a mediaeval and anonymous Sanskrit-Tibetan-Chinese technical dictionary. For the history of this work see the introduction to the Kyōto edition of the book itself. 


\section{PART I \\ 1. COSMIC SYNTHESIS \\ Methods of Computation}

Numerical Expressions.

The detailed examination of Buddhist cosmography must begin with a consideration of the most frequently employed numerical terms. Unfortunately there is very little uniformity in this matter, and each school seems to have its own numerical sequence. With most of these we need not be concerned, but it may be of advantage to cite two of the most common and important.

In the first of these, taken from the Mahāvyutpātti (p. 514), we find the following comparatively simple scheme:-

$\begin{array}{ll}10 \text { tens } & =1 \text { hundred (Śata). } \\ 10 \text { hundreds } & =1 \text { thousand (Sahasra). } \\ 10 \text { thousands } & =1 \text { ayuta. } \\ 10 \text { ayutas } & =1 \text { lakṣa. } \\ 10 \text { lakșas } & =1 \text { niyuta. } \\ 10 \text { niyutas } & =1 \text { koți. } \\ 10 \text { koțis } & =1 \text { arbuda. } \\ 10 \text { nyarbudas } & =1 \text { padma. } \\ 10 \text { padmas } & =1 \text { kharva. } \\ 10 \text { kharvas } & =1 \text { nikharva. } \\ 10 \text { nikharvas } & =1 \text { mahäpadma. } \\ 10 \text { mahäpadmas } & =1 \text { śañu. } \\ 10 \text { sañkus } & =1 \text { samudra. } \\ 10 \text { samudras } & =1 \text { madhya. } \\ 10 \text { madhyas } & =1 \text { atța. } \\ 10 \text { atțas } & =1 \text { parärdha. }\end{array}$

The enumeration found in the Abhidharma Kośa (12-5b) is as follows:-

10 ones

10 tens

10 hundreds make ten.

, a hundred.

, a thousand. 
10 thousands

10 prabhedas

10 lakșas

10 atilakṣas

10 koțis

10 madhyas

10 ayutas

10 mahāyutas

10 nayutas

10 mahānayutas

10 prasutas

10 mahāprasutas

10 kamkaras

10 mahākaṃkaras

10 bimbaras

10 mahābimbaras

10 akșobhyas

10 mahākṣobhyas

10 vivahas

10 mahāvivahas

10 utsangas

10 mahotsañgas

10 vahanas

10 mahāvahanas

10 titibhas

10 mahāțițibhas

10 hetus

10 mahāhetus

10 karabhas

10 mahākarabhas

10 indras

10 mahendras

10 samāptas

10 mahāsamāptas

10 gatis

10 mahāgatis make a prabheda.

a lakșa.

an atilakṣa.

a koți.

a madhya.

an ayuta.

a mahāyuta.

a nayuta.

a mahānayuta.

a prasuta.

a mahāprasuta.

a kamkara.

a mahākaṃkara.

a bimbara.

a mahābimbara.

an aksobhya.

a mahākșobhya.

a vivaha.

a mahāvivaha.

a utsanga.

a mahotsañga.

a vahana.

a mahāvahana.

a titibha.

a mahāțițibha.

a hetu.

a mahāhetu.

a karabha.

a mahākarabha.

an indra.

a mahendra.

a samāpta.

a mahāsamāpta.

a gati.

a mahāgati.

a nimbaraja. 
10 nimbarajas make a mahānimbaraja.

10 mahānimbarajas ", a mudrā.

10 mudrās

10 mahāmudrās

a mahāmudrā.

10 balas

10 mahābalas

10 samjjñas

10 mahāsamjjñas

10 vibhūtas

10 mahāvibhūtas

10 balakṣas

10 mahābalakṣas

a bala.

a mahābala.

a samjũa.

a mahāsamijña.

a vibhūta.

" a mahāvibhūta.

" a balakșa.

, a mahābalakșa.

, an asamkhya.

Incidentally, asaṃhya means " countless", and accordingly we find that this title is not strictly true, since its exact significance can thus be discovered.

Among the many other well-known numerical sequences are those found in the Lalita Vistara, the Saddharma Pundarika, and the Avatamsaka, ${ }^{1}$ but the fact that such schemes were purely fanciful, and were never used for practical purposes, permits us to leave them unnoticed.

The Computation of Size and Distance.

The ultimate or smallest unit in the computation of size and distance was the paramānu or atom. For the calculation of size from this paramānu to the anguli (digit or Buddhist inch) we frequently find the following curious old table ${ }^{2}$ :7 paramānus make 1 anu.

7 anus

, 1 loharajas or metal dust with 49 paramānuus.

7 loharajas $\quad$ " 1 abrajas or minute particle of water, with 343 paramāṇus.

1 Lal. Vist. (L.'s ed.), p. 149, agrees with Ch. Sad. Pun. Burnouf's trans. append. agrees with Ch. Avat.f. 48 of 60 f.ed. and f. 65 of 80 f. ed. (both Ch.). For Ceylon M.B. 6, K. i, 336.

${ }^{2}$ A.K. 12-1b ; M.V. 136-1 b : for South K. i, 335. M.Vy. 520. 
7 abrajas

7 śaśarajas

7 avirajas

7 gorajas

7 vātāyanacchidrarajas

7 likṣā

7 yūka

7 yava make 1 śaśarajas or hare or rabbit dust, or minute portion of rabbit's dung, with 2,401 paramāṇus.

, 1 avirajas or sheep dust, etc., with 16,807 paramānus.

„ 1 gorajas or cow or ox dust, etc., with 117,649 paramānuus.

" a vātāyanacchidrarajas or the mote in a sunbeam (entering by a hole in the window), with 823,543 paramānus.

, 1 likṣā or nit with $5,764,801$ paramāṇus.

, 1 yūka or louse with $40,353,607$ paramāṇus.

, 1 yava or barley grain, with $282,175,249$ paramāṇus.

, 1 anguli or digit, with $1,975,226,743$. A digit is about $\frac{3}{4}$ in.

Up to this point the units are largely of theoretical interest. The larger figures, used in everyday life, are enumerated in the Abhidharma Kośa ${ }^{1}$ as follows :-

3 anguli-parva or finger-joints $=1$ anguli or digit.

24 anguli

4 hasta 5,000 dhanus

8 krośas
$=1$ hasta, fore-arm, or cubit.

$=1$ dhanu or bow, a fathom or 6 feet. $=1 \mathrm{krosia}, 500$ fathoms or 3,000 feet. $=1$ yojana, the Buddhist mile.

This, though the orthodox computation, was by no means universal. More particularly the yojana, like the Chinese li, had a very fluctuating value. Sometimes it is spoken of as equivalent to 4,650 feet, others give $4 \frac{1}{2}$ or 5 miles, the nearest to the Abhidharma Kośa figure; other authorities give $6 \frac{1}{2}$, 
$7,7 \frac{1}{4}, 7 \frac{2}{3}, 9,12 \frac{1}{2}, 16$ miles. The use of the term by the Chinese pilgrims was inconsistent and contradictory.

\section{The Smaller Periods of Time.}

Discrepancies concerning the computation of time also occur, but are less frequent. The kṣana is always the smallest unit. Some say that it is the 90th part of the duration of a thought, or the 4,500th part of a minute, while the Mahāvibhāṣa states that 6,499,099,980 such kṣaṇas comprise one day.

The Abhidharma Kośa ${ }^{1}$ gives us the following list :-

120 kṣaṇas make a tatkṣaṇa.

60 tatkṣaṇas ,, a lava.

30 lavas " a muhūrta (48 Euro. minutes).

5 muhūrtas ", a kāla (Bud. hour).

6 kālas „, a day (of 24 Euro. hours).

These kālas were grouped as follows ${ }^{2}:$ (1) Trisandhya or three day watches, forenoon or pūrvāhṇa, noon or Madhyāhna, and afternoon or Aparāhṇa. (2) Three night watches, first watch Prathama-yāma, midnight watch or Madhyama-yāma, and the last watch or Paścima-yāma. Incidentally, Hsüan Tsang ${ }^{3}$ adds that though this is the official Buddhist calculation, many Buddhists in India adopted an eight-period instead of a six-period day, four periods in the daytime and four in the night.

\section{The Months and Seasons. ${ }^{4}$}

Thirty Vasantas or days and nights make one Māsa or month, this being subdivided into two pakșa or half months: (a) Sukla pakșa, the white period, when the moon is waxing;

1 12-2a. See also Loka-prajñapti, 5-5a, for full account.

2 M.Vy. $522 \mathrm{ff}$.

3 Watters, "On Yuan Chuang," section on Indian time.

- For all such calculations M.Vy. 522, for Ceylon M.B. 23. For the North account of seasons see particularly appendix to I-ching's travels, Takakusu's translation. 


\section{MANUAL OF BUDDHIST PHILOSOPHY}

and (b) Kṛșna pakșa, or dark period, when the moon is waning. There are, further, twelve Varșa or months in a year, viz. :-

1. Caitra.

2. Vaiśākha.

3. Jyaistha.

4. Āsāduha.

5. Srāvaña.

6. Bhādrapada.
7. Āśvina.

8. Kārttika.

9. Mārgaśírșa.

10. Paușa.

11. Māgha.

12. Phālguna.

We find that there were several ways of classifying the months into seasons. There was, in fact, a two-fold, a threefold, a four-fold, a five-fold, and a six-fold classification.

1. The Two-fold Classification.-This consists of the Ayanas or marches, so called because during the one the sun gradually moved to the north, and during the other it gradually moved to the south. This division will be given more detailed consideration when dealing hereafter with Buddhist astronomy. Each of these seasons contained exactly six months.

2. The Three-fold Classification--Hsüan Tsang informs us that the most common division of the year was into three seasons, winter, spring, and summer, or, better, the cold, the rainy, and the hot seasons.

3. The Four-fold Classification.-This was the classification of the months upon which most theoretical emphasis was laid. It corresponds to our own division of the year into spring, summer, autumn, and winter, each season containing three months.

4. The Five-fold Classification.-The Vinaya, or Canon Law, treats this classification as the most orthodox. It consists of (1) a winter season of four months, (2) a spring of four months, (3) a rainy season of one month, (4) a last season of only one night and day, and (5) a summer season of five months.

(5) The Six-fold Classification.-This division, of which 
quite frequent mention is made, consists of six seasons, each one containing two months. Their names are :-

1. Vasanta, Spring.

2. Grịsma, or later Spring.

3. Varsā, Summer, or the rainy season.

4. Śarāt, or Autumn.

5. Hemanta, or Winter.

6. Siśira, or later Winter.

The Yugas, Smaller, Middle, and Larger Kalpas.

In later times Buddhism tended to accept the secular chronology of the various countries which it overran as regards the smaller periods of time, but the larger units continued to be an integral part of Buddhist philosophy. These are :-

The Yugas.-According to Buddhism the average duration of a man's life, far from being constant, is constantly fluctuating, as is his stature also, since it varies between the average height of one foot and a half and an average life of ten years, until his stature is overwhelming, and his life approximates 80,000 years, and then as gradually dwindles to its original proportions and duration. The periods of increase, or Utkarșa, and decrease, or Apakarșa, are both divided into four sub-periods, known as Yugas, ${ }^{1}$ and are called :

1. Krrta yuga, the age of perfection, when man lives an asamkhya, and all are blissful.

2. Tretā yuga, when the size, duration of life, and happiness of beings is diminished.

3. Dvāpara yuga, when all these features are but half of that of the Krrta yuga.

4. Kali yuga, or the age of degeneration and quarrelling.

Life begins with a Krta yuga, and then degenerates to a Kali yuga, then starts with a second Kali yuga before going up the scale again. According to some accounts the longest

1 M.Vy. 527, A.K. 12-12a; for Ceylon M.B. 7. 
period of human life is an Asamkhya. Very frequently, however, it is epitomized by the figure 80 or 84,000 , the usual Buddhist manner in speaking of large numbers.

Small Kalpa. ${ }^{1}$-The whole of the eight yugas taken together forms a small or antara kalpa. This small kalpa, then, is equivalent to the period which it takes for man's life to increase and decrease to the maximum, the rate of such increase being computed at one year in every hundred. It is not, however, necessary for such an increase and decrease to take place in an antara kalpa, for, as we shall see later, there are certain epochs when for a whole antara kalpa there is no sentient existence at all. It is merely a fixed period of time.

Middle Kalpas.-These smaller kalpas are further grouped together in sets of twenty, the whole of which period is called a Middle or Asamkhya kalpa. These middle kalpas are, again, of four kinds, which succeed one another in the following order :-

1. Vivarta kalpa, or the middle kalpa of formation, during which the world comes into existence, and its first inhabitants are spontaneously and automatically born.

2. Vivarta-siddha kalpa, or the middle kalpa of the continued formation, or the prime of the world.

3. Samvarta kalpa, or the middle kalpa of destruction, during which the world gradually degenerates, and is finally destroyed.

4. Samvarta-siddha kalpa, or the kalpa of the continuance of destruction, during which the world is nonexistent and all is void.

A Samvarta-siddha-kalpa is followed by another Vivarta kalpa, and so on eternally. It should be noted that the destruction of the world does not mean the destruction of the universe, since, as we shall later have occasion to observe, Buddhism postulates the existence of an infinite number of inhabited worlds.

1 For the Kalpas F.T. 30-2a. F.Ch. $2 b$ and $6 a$. A.K. 12-12 ff. 
Great Kalpa.-The entire cycle of the four middle kalpas is called a Mahākalpa or great kalpa, which is the largest unit of calculation. Each such great kalpa is the cyclic period of a world, during which time the whole drama of creation and destruction is played. The great kalpas consist of four middle kalpas, and as each middle kalpa consists of twenty small kalpas, a great kalpa contains eighty small kalpas. The following chart may serve as an aid in memorizing this list :-

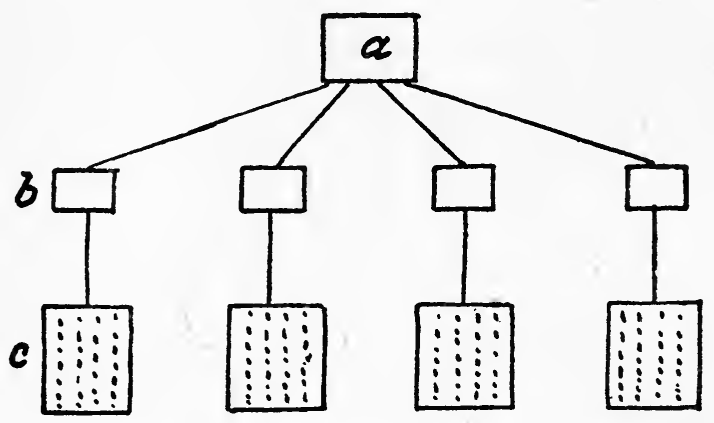

(a) Great Kalpa. (b) Middle Kalpa. (c) Small Kalpa.

\section{Other Chronological Cycles.}

In addition to this more or less mathematical computation of time, Buddhism makes frequent mention of various other cycles, mostly with a more religious significance. Of cosmological reference are the three Great Calamities, ${ }^{1}$ cycles of destruction of the world through fire, water, and wind ; the three Smaller Calamities, ${ }^{2}$ cycles of evil which occur whenever the duration of human life reaches its lowest ebb. Again, kalpas are grouped into $(a)$ those in which Buddhas do and $(b)$ do not appear. Again, inside of each kalpa there are only certain epochs ${ }^{3}$ when Buddhas, Pratyeka Buddhas, and

1 A.K. 12-16a; N.A. 32-20; D.A. $110 a$.

A.K. $12-14 b$; N.A. $32-18 b$.

A.K. $12-8 a$; N.A. 32-9a. 
Cakravārtins may be born. Finally, in connexion with the duration of the doctrine of each Buddha there is a cycle of the three-fold law, ${ }^{1}$ viz. : (1) the period of the True Law, the Buddha doctrine in its purity, lasting for five hundred years after the death of the founder; (2) the period of the Image Law, when men lose the spirit and cling to the letter of the law, lasting for a thousand years; (3) the period of the Decay of the Law, during which the doctrine becomes corrupt and defiled, lasting, according to some, one thousand years, according to others ten thousand.

\section{COSMIC GEOGRAPHY}

\section{World Systems.}

The interaction of the atoms and elements brings about the formation of the universe. In common with other Indian philosophies, Buddhism taught that the universe consists of an infinite number of worlds, all more or less on the same plan as our own, with the same number of mountain ranges, continents, oceans, etc., together with the other features of Buddhist cosmography, including the hells in the interior of, and the heavens above, each world.

The number of these worlds is really incalculable. Their number runs into infinitude, and they are scattered through all the six directions of space. ${ }^{2}$ These worlds are grouped in various kinds of chiliocosms. A small chiliocosm consists of a thousand cakravālas or worlds, and is encompassed by a gigantic wall. A middle chiliocosm consists of a thousand small chiliocosms, with a similar wall. A large chiliocosm consists of a thousand middle chiliocosms, and is likewise furnished with an encompassing wall. A small chiliocosm contains 1,000 , a middle chiliocosm contains $1,000,000$, and a large chiliocosm 1,000,000,000 worlds. $^{3}$ The Abhidharma Kośa informs us

1 F.Ch. 3)-4a.

2 M.B. 2. [M.B. = Spence Hardy's Manual of Buddhism.]

3 M.B. 8 ; A.K. 11-15a; N.A. 31-20a; F.A. 32-7a; D.A. $92 a$; A.V.P. $1-5 a$. 
that the distance between two worlds is $1,203,450$ yojanas. Our own chiliocosm is known as the Saha world, which means either the place of suffering or the capital of a chiliocosm, and is that to which Sankyamuni limited the revelation of himself.

\section{Classification of the World Systems.}

The infinity of space and the countless number of worlds which it contains, being admitted, the next task is to discover how Buddhism sets about classifying them.

Hinayāna, with its doctrine of the rarity of the Buddhas, divides the universe into three categories: (1) Cakravālas which appear to the Buddhas, but which do not receive his Dharma, and in which a Buddha is never born; (2) Cakravālas receiving the Dharma of the Buddhas, but in which a Buddha is never born; (3) Cakravālas in which Supreme Buddhas themselves appear. This division is late and applies only to certain branches of Hinayāna, chiefly the southern branches. ${ }^{1}$ The tendency of Northern Buddhism, especially Mahāyāna, was to universalize Buddhahood.

Perhaps the most important division of the universe into the three regions of Kāma or Desire; Rūpa or Form ; and Arūpa or Formlessness. ${ }^{2}$ This classification is common to all forms of Buddhism, and must therefore be considered somewhat more in detail.

The Kāma dhātus or worlds of desire consist of those realms where the inhabitants still suffer from various passions. Those in the lower regions are still subject to pain; those in the upper regions enjoy a physical and sensuous pleasure. This realm includes the material worlds, or earths with the various forms of life contained therein, and the six Käma heavens.

The Rūpa dhätus are those realms in which the lower forms of desire are exterminated, but in which the inhabitants are

1 In Ceylon (cf. M.B.) it is said that the Cakravãlas always go in groups of three, arranged as follows $\therefore$. This doctrine is unknown in the North.

2 A.K. 8-1a. 
still possessed of figure and shape, and are still susceptible to the finer forms of intellectual desire. This realm consists of sixteen, seventeen, or eighteen Brahmā heavens situate above each Käma dhātu.

The Arūpa dhātus are those realms wherein even figure and body disappear, and only life remains. These realms are generally enumerated as four, in the first three of which there still exists some form of consciousness, while in the fourth there is neither consciousness nor unconsciousness.

In addition to these, Mahāyāna postulates an infinite number of Buddhaksetras or Buddha lands in which the highest followers of Buddhism are reborn.

A more detailed examination of these three realms had best be divided in the following way: (1) A description of the cosmic geography of the Buddhists, or a chart of the configuration of the earth. (2) A table of the various heavens and hells, etc., which are to be found in the bowels of or above the earth. (3) Description of the various beings who are supposed to inhabit these regions.

\section{The Earth's Foundation.}

The basis of each world is a material earth, and since each world and therefore each earth is uniform, the general plan of one earth holds good for all others.

All the Sūtras and Sāstras agree that the earth is in the shape of a cylinder, the visible world being on the flat section on top, while the cylinder proper consists of layers of different kinds of materials. These layers are composed as follows ${ }^{1}$ :-

1. At the very bottom of each earth, and thus supporting is the infinite and thus unmeasurable world of Ākáśa, space or ether, which at the same time is above, around, and in each of the other spheres.

2. Above this there is a layer of air or wind, solid and immovable to such an extent that it cannot be penetrated

1 A.K. 11-1 $a$; N.A. $31-1 a$; M.V. $133-4 a$; F.A. $32-15 a$; D.A. $92 a$; Y.B. $27 a$; cf. Ceylon accounts M.B. 
by diamonds. It is $1,600,000$ yojanas in depth, but its diameter and circumference cannot be measured.

3. Above this is the layer of water, 800,000 yojanas deep, with a circumference of $3,610,350$ yojanas.

4. Above this is a layer of gold, or hard rock, in contradistinction to the soft mould of which the earth proper is composed. It is 320,000 yojanas deep, and has the same circumference as that of water.

5. Finally, there is the layer of earth proper, 80,000 yojanas deep, on top of which are the various mountains, oceans, continents, etc. Its circumference is the same as the preceding two.

The earth is supposed to be created, held together, and generally sustained and supported by the aggregate result of the actions of all sentient beings. The manner of its creation and destruction will be described hereafter.

\section{Mahāmeru, the Central Mountain.1}

In the exact centre of this and all other worlds is situate a huge mountain, which is the navel of the earth, and concerning which many legends have arisen. Various supernatural beings are on its sides, on its summit, as well as immediately above it.

Its total height above the surface of the central sea which surrounds it is 80,000 yojanas, and below its surface it reaches down to the bottom of the earthly layer (another 80,000 yojanas). Regarding its diameter, there is much difference of opinion. ${ }^{2}$ All agree that the greatest diameter is at its base (i.e. sea-level) and at its summit, the smallest portion being between these two parts. The maximum diameter is the same as the height, 80,000 yojanas. On the sides are certain excrescences, which are the abode of certain of the deities, such as the four tiers of heavens ruled over by the

1 A.K. 11-2a ; F.L. $32-8 b$; Y.B. 2-7a. For Ceylon M.B. 10 ; K.I. 187.

2 For Ceylon M.B. 10. 
Catur Mahārājikas (the Four Great Kings), or the guardians of the four directions.

Each of these rulers has his own especial colour, which he imparts to the territory over which he rules, so that each side of the central mountain has a different hue, as have the seas, rocks, atmosphere, etc., in each direction. By reason of the intermingling of these four primal colours in those parts where they overlap, eight shades are enumerated, viz. :-

1. In the north, Gold.

2. In the north-east, Virgin Gold.

3. In the east, Silver.

4. In the south-east, Pale Blue.

5. In the south, Blue.

6. In the south-west, Purple.

7. In the west, Red.

8. In the north-west, Golden Red.

To the Buddhists, the whole of the known world formed but a part of Jambüdvipa, the great southern continent, which accounts for the fact that to us the sky seems blue, but for the people inhabiting other continents in other directions the sky has a different colour.

The Seven Rocky Circles.

Ranged around Mahāmeru (at intervals between which are oceans) are seven rocky or mountainous circles, gradually decreasing in altitude and increasing in circumference. As regards altitude, the extent of each mountain under the water is the same (80,000 yojanas). ${ }^{1}$ The altitude of each mountain above the water decreases by half, and the diameter of each is the same as the extent of its elevation above water. Thus these circles ${ }^{2}$ are :-

1. Yugamdhara.-It surrounds Meru on all sides, though separated from it by an ocean 80,000 yojanas wide. Being

1 Here and elsewhere A.K. has 80,000, D.A. has 84,000, as the basis of calculation. Other works vary between the two. I follow A.K.

2 M.Vy. 280. No two accounts give the same list, see comp. chart, K.I. 186 ; also M.B. 12 ; A.K. 11-2a ; M.V. 133-13b ; Y.B. 2-7b. 
half the total height of Meru, its altitude above the water and its diameter is 40,000 yojanas.

2. Is âdhara, separated from Yugaṃdhara by a sea 40,000 yojanas wide, has an altitude above the water and a diameter of 20,000 yojanas.

3. Khadiraka is separated from İsādhara by a sea 20,000 yojanas wide, has an altitude and diameter of 10,000 yojanas.

4. Sudarśana is separated from Khadiraka by an ocean 10,000 yojanas wide, has an altitude and diameter of 5,000 yojanas.

5. Aśvakarna is separated from Sudarśana by a sea 5,000 yojanas wide, has an altitude and diameter of 2,500 yojanas.

6. Vinataka is separated from Aśvakarna by a sea 2,500 yojanas wide, has an altitude and diameter of 1,250 yojanas.

7. Nimimdhara, the last of the rocky circles, separated from Vinataka by a sea 1,250 yojanas wide, has an altitude and diameter of 625 yojanas.

Stretched around this last rocky circle is the great salt ocean, gradually decreasing in depth from 625 yojanas, near Nimimdhara, to where it is but 1 inch deep. This is the circumference of the earth, and here there is another encircling mountain, this time made of iron, called the Cakravallagala, or Cakravāda. This is but a half of the altitude of Nimimdhara, and is therefore $312 \frac{1}{2}$ yojanas high. According to other accounts, there are two such mountains, one separated a short distance from the other by a space reaching down to the circle of water in which are found some of the most dismal of the hells.

The Great Oceans. ${ }^{1}$

We have already seen that between each of the rocky circles

1 A.K. $11-3 b$; N.A. $31-3 a$; F.T. $32-9 a=$ Y.B. $2-7 b .=($ M.B. 12 ; K.I. 183 for South). 
is an ocean. The salt ocean, or that between Nimimdhara and the outer circle, is the ocean in which are placed all the inhabited continents, and so is the only one known to mankind. All of the first seven oceans are 80,000 yojanas deep. Their diameter has been given above. The depth of the salt ocean has also been stated. Its width is 322,000 yojanas. The circumference of the whole earth or Cakravāla, and therefore the outer circumference of the salt ocean, is $3,610,350$ yojanas.

Incidentally the figures for the diameter of the earth may be of interest. The Abhidharma Kośa gives the following enumeration. Meru having a diameter of 80,000 yojanas, its radius is 40,000 . From the outermost point of Meru to the outermost point of Nimimdhara is 158,750 yojanas (79,375 being land, and an equal amount water). Across the salt ocean it is 322,000 yojanas, or more exactly 322,312 yojanas, so that the total diameter of the earth is $1,042,124$ yojanas.

According to some accounts, the interior seas are filled with various kinds of perfumed waters. The Abhidharma Kosa, however, merely says that their waters possess the eight magic qualities: (1) purity, (2) coolness, (3) sweetness, (4) softness, (5) lightness, (6) fragrance, (7) while drinking it does not injure the mouth, (8) when drunk it does not injure the stomach.

Various reasons are given for the saltness of the eighth or great ocean. The following are the most frequent: (1) In the middle of the sea is a great fish, whose pollutions cause the salt taste; (2) in the ancient days a Rși used his magic powers to effect the brackishness ; (3) the salt taste is caused by the earth's impurities, which have been washed away into the sea.

The ocean does not overflow in spite of the water constantly being added by the rivers, because there are four jewels at the bottom of the ocean, which absorb all the surplus water. These change the water into various things, which eventually disappear, leaving no residuum. The tides were explained 
by the theory that the water at stated periods flows in and out of the palace of the Nãga king, situate at the bottom of the sea.

\section{The Four Great Continents. ${ }^{1}$}

Located in the eighth, or outermost, or salt ocean, and outside Nimimdhara or the seventh rocky circle are the four great continents, one on each side of the world.

1. On the North, 8,000 yojanas in extent, is the ideal continent, Uttarakuru, square in shape, like a chair or the lid of a box having four equal sides, each side 2,000 yojanas long. ${ }^{2}$

2. On the East, 7,500 or 7,000 yojanas in extent, is Pūrvavideha, in the shape of a half-moon. According to the Abhidharma Kośa, it has three sides of 2,000 yojanas each, and a fourth of 350 yojanas.

3. On the West is Aparagodāniya or Godaniya, in shape round, like the full moon, 7,500 or 7,000 yojanas in circumference, with a diameter of 2,500 yojanas.

4. On the South there is the great continent Jambüdvipa, in shape like a triangle (with the point facing south), having a circumference somewhat over 6,000 yojanas. The Abhidharma Kośa states that three of its sides are 2,000 yojanas long, and a fourth only $3 \frac{1}{2}$.

Most accounts further add that in the vicinity and on each side of these four continents there are two large islands or sub-continents (i.e. one on each side), making in all twelve large inhabited portions of the world. Connected with the northern continent are the islands Kurava and Kaurava; with the eastern continent Deha and Videha; with the western continent Sātha and Uttaramantrina; with the southern continent Cāmara and Aparacāmara. All are inhabited by some species of man, though, according to one account, Cāmara is inhabited only by rakṣas or demons.

1 A.K. 11-4a ; F.T. 32-8b; Y.B. 2-7b; M.Vy. 217.

${ }^{2}$ For Ceylon amplifications M.B. 15, for the North D.A. $94 \mathrm{ff}$. 
In the early stages of Buddhist cosmology, Jambūdvipa consisted only of India and the immediately surrounding countries, the other portions of the world being unknown. Later, when Japan, China, Central Asia, etc., came to be known, they were likewise counted as part of the same continent. Still later, Europe, Africa, and even America were put in the same category.

A great many mythical details were added to the Buddhist descriptions of Jambüdvipa, chiefly with reference to the principal mountains, lakes, rivers, and forests. ${ }^{1}$ With these, however, we need not concern ourselves, and may rest content with referring the curious to the principal original authorities.

\section{Buddhist Astronomy. ${ }^{2}$}

All schools of Buddhism taught that attached to each Cakravāla there is a sun and moon, as well as a multitude of stars, all comparatively small bodies which move in their orbit around Mount Meru, causing the division into days, nights, months, years, etc. Both the sun and the moon were supposed to be about 40,000 yojanas above the level of the sea or the same height as Yugamdhara, the first of the rocky circles, so that this circle and Meru itself hid their rays from the continents lying on the other side from which the sun and moon happened for the moment to be. Both sun and moon continually revolve around Meru, the path of their orbit being between Nimimdhara and the outer circle, or, in other words, above the great salt ocean. Consequently, when it is day in the southern continent it is night in the northern continent, sunset in the eastern continent, and sunrise in the western continent.

The Abhidharma Kośa states that the dise of the sun is 51 yojanas in diameter, that of the moon 50 . The sun is composed of gold and crystal; the moon of silver and lapis

1 For Ceylon amplifications M.B. $15 \mathrm{ff}$; ; for the North D.A. $93 \mathrm{ff}$.

2 A.K. 11-8b; N.A. 31-12a ; F.A. 32-16a. Cf. M.B. 20, showing differences of Southern accounts, where sun $=50 \mathrm{yoj}$. and moon $=40$ yoj. 
lazuli. According to some accounts, the sun is really square, and only its movement and its distance make it seem round. In the sun is the palace of the sun god, Surya, and in the moon that of the moon god, Candra. Each palace is 16 yojanas high, and 8 yojanas square.

Frequent mention is made of the two-fold path or marches of the sun, the northern and the southern. ${ }^{1}$ For the six months of the southern march the sun gradually passes $5 \frac{1}{2}$ yojanas beyond the southern limit of the southern continent Jambūdvīpa, and shines directly over the sea, while during the northern march its orbit is such that the sun shines directly upon the continent itself. For this reason the days are colder in winter, since the rays of the sun fall upon the ocean rather than upon the continent itself, while for the inverse reason it is warmer in summer. For the same reasons, when the orbit of the sun gradually passes to the south the days little by little become shorter and the nights longer, while during the period when the sun swings to the north the days are longer and the nights shorter. At the time when the days are longest, out of the thirty muhūrtas into which the day and night are divided, the days have eighteen muhūrtas and the nights twelve, and vice versa when the orbit is changed. During the middle course the days and nights have fifteen muhūrtas each.

The rays of the sun are always the same, neither increasing nor decreasing in heat. The seeming difference in their intensity is due to the change in orbit, the intervention of clouds which act as a screen, to mists that arise from the ground, and to the actions of Rāhu the great Asura, who occasionally eclipses the sun by swallowing it.

With regard to the moon, several reasons are advanced to account for its phases. Most important, however, is the fact that when it is near the sun the overpowering light of the latter prevents its own light from being seen, etc. While it

1 According to M.B. 21, the Ceylonese count three paths instead of two marches. 
takes the sun six months to change from its northern to its southern path, the moon undergoes its entire cycle of change in one month.

With regard to the stars, we are told that they are innumerable, there being 80,000 of especial note. They are made of a very pure material, and are inhabited by devas belonging to the realm of the Four Great Kings. In ancient days the stars were arranged into a number of different constellations, a certain number being assigned to each country, whereby it and its inhabitants might be protected. Consequently, each quarter has its own protecting stars; in the east six asterisms, and in the other three quarters seven each. There are, in addition, nine planets, counting the sun and moon as two. Apart from these last two, there are ${ }^{1}:-$

1. Añgāraka $=$ Mars.

2. Budha = Mercury.

3. Bṛhaspati = Venus.

4. Sukra = Venus.

5. Śanaiscara = Saturn.

6 and 7 Rāhu and Ketu, the two great Asuras, sometimes called the ascending and descending mode respectively.

As regards the size of these stars, we find widely differing accounts. According to the Lokaprajñapti, the largest are 18 krośas, the smallest 3 krośas, the average size being 10 or 12 krośas.

\section{The Signs of the Zodiac.}

Along with other astronomical ideas, the Buddhists adopted the usual enumeration of the twelve signs of the solar, and the twenty-seven or twenty-eight signs of the lunar zodiac. Strangely enough the latter was much better known. I have found no mention of the solar zodiac in any old Hīnayāna 
work. $^{1}$ In the Sannipāta Sūtra (a late Mahāyāna work) the twelve signs of the solar zodiac are :-
1. A red ram
$=$ Aries.
2. A white bull
$=$ Taurus.
3. A man and a woman = Virgo.
4. $A$ red crab
$=$ Cancer.
5. A red lion
$=$ Leo.
6. A black virgin
$=$ Gemini.
7. A pair of scales
$=$ Libra.
8. A black elk
$=$ Scorpio.
9. A centaur
$=$ Sagittarius.
10. A sea monster
$=$ Capricorn.
11. A white man
$=$ Aquarius.
12. Two fish
$=$ Pisces.

The fact that there must have been some historical connexion between the eastern and western zodiacs is obvious.

The twenty-eight members of the lunar zodiac are also found among the early Hindus, Arabians, and Chinese. Their Sanskrit names are as follows ${ }^{2}:-$

1. Krttikā.

2. Rohinī.

3. Mrrgaśiras.

4. Ārdrā.

5. Punarvāsu.

6. Pusya.

7. Aśleșā.

8. Maghā.

9. Pūrvaphalgunī.

10. Uttaraphalgunī.

11. Hastā.

12. Citrā.

13. Svāti.

14. Viśākhā.
15. Anurādhā.

16. Jyeșțhā.

17. Mūlām.

18. Pūrvāsāḍhā.

19. Uttarāṣāḍhā.

20. Sravanāà.

21. Abhijit.

22. Satabhișaj.

23. Dhanișthā.

24. Pūrvabhadrapadā.

25. Uttarabhadrapadā.

26. Revatī.

27. Aśvinī.

28. Bharaniî.

1 But M.B. 23 gives it for Ceylon.

2 M.Vy. 225, cf. M.B. 24, on the influence of these signs F.T. 32-17a. 


\section{THE DIVISIONS OF THE THREE DHĀTUS}

The Relation between the Dhätus and the Earth.

Having thus briefly disposed of the receptacle or material world, we are now free to examine the spacial relation that exists between the earth and the various divisions of the three dhātus. This may be expressed in the following way ${ }^{1}$ :-

\section{The Arūpa Dhātu}

The four arūpa heavens have no spacial abode, and, consequently, have no place in cosmic geography.

\section{The Rūpa Dhātu}

The sixteen, seventeen, or eighteen heavens of the Rūpa Dhātu are all arranged in tiers of three or more, high above the earth.

\section{The Kāma Dhātu}

1. The six Käma heavens.-Four are above the earth, and below the Rūpa heavens. One is on the summit of Mount Meru. One is half-way down its sides.

2. Mankind inhabit the four continents.

3. The Pretas are sometimes just under the earth, sometimes on its surface.

4. The Animals are sometimes in the air or on the earth, but mostly in the water.

5. The Hells are for the most part in the bowels of the earth, directly under Jambūdvipa.

The prominent part which each of these divisions and subdivisions of the three dhätus has played in Buddhist speculation renders necessary a somewhat more detailed explanation of each.

Kāma Dhātu. The Hells. ${ }^{2}$

Buddhism postulates an infinite number of hells, with various degrees of torture according to the amount of evil

1 A.K. 8-1a. 2 A.K. 11-5b; N.A. 31-5a; D.A. $97 b$ ff. = Y.B. 4-14a. 
wrought by the person concerned. In addition to certain hells outside the limits of this Cakravāla, these Narakas, or places of suffering, may be grouped under four heads, viz. :-

1. The 84,000 smaller Lokāntarika, or frontier hells, situated upon the face of the earth, such as $(a)$ on the mountains, $(b)$ on the water, $(c)$ in the desert.

2. The dark hells, eight in number, placed on the outskirts of the Cakravāla; also called the vivifying hells, because any being dying in the first of these hells, is reborn in the second, and so on.

3. The cold hells, eight in number, situated either on the outskirts of the earth, or underneath the southern continent.

4. The hot hells, ${ }^{1}$ also eight in number. All accounts agree in placing them under Jambüdvipa. We find but casual mention of the first two types of hell, so that we may pass them over in silence. The cold hells, also, are of less importance, but are sufficiently frequently enumerated to make their names important. They $\operatorname{are}^{2}$ :-

1. Arbuda, where the cold is so great that the flesh breaks out in sores.

2. Nirarbuda, where the whole body swells and blisters from the cold.

3. Atata, where the culprit's lips are so frozen that he can utter but this one sound.

4. Hahava, where only this sound can be uttered.

5. Huhuva, where no articulate sound is possible, but the cold wind in the throat imitates this sound.

6. Utpala, where the cold sores resemble the buds of the blue lotus (utpala).

7. Padma, where the cold sores become red and inflamed like the red lotus (padma).

8. Mahāpadma or Pundarika, where the sores resemble great lotuses (mahāpadma) or white lotuses (puṇḍarika).

1 These are the only ones commonly known in the South. Cf. M.B. 27.

2 M. $\nabla y .326$. 
According to most accounts, including the Abhidharma Kośa, these hells are underneath the southern continent, near the hot hells, and ranged shaft-like one underneath another, but in such a way that the middle or fourth hell is widest, and the top and bottom hell the narrowest. Other accounts claim that these cold hells are on the outer circumference of the world, between the two Cakravālas.

The hot hells are as follows :-

1. Samjivva, where the victims tear one another's flesh by means of metal claws, and are then destroyed by fire, but are revived by a cool wind in order to undergo further torture. The reward of evil action as regards the body, tongue, and mind.

2. Kälasütra, the hell of black ropes, so called because the victims are loaded with fiery chains. The reward of evil actions against one's parents, a monk, or the Buddha, etc.

3. Samghāta, or the hell of collected misery, the reward of accumulated sins, especially arising from the threefold bonds : ignorance, lust, and anger.

4. Raurava, or the hell of lamentations, from the shrieks uttered by the victims thrust into fiery iron cauldrons. The reward of murderers and poisoners.

5. Mahāraurava, the hell of great lamentations, where similar but more intense forms of suffering to the preceding are undergone. The reward of heretics and malefactors.

6. Täpana, the hell of burning heat, where the victims are burnt in iron ovens. The reward of those who have burnt living beings.

7. Pratapana, the hell of extreme heat, where the victims are thrust in a lake of fire, and pierced with iron spikes when they attempt to escape. The reward of habitual malefactors and apostates.

8. Avici, or the non-intermittent hell, so called because there is no intermission in the suffering, and because 
the suffering is unmixed with any form of pleasure. The reward of the most serious offences.

With regard to the location of these Narakas, the commentaries say that immediately below the earth's surface there is an earthy loam of 500 yojanas depth, then another layer of white clay likewise 500 yojanas deep. Below this is Samjiviva, and the six following hells, one under another, occupying in all the space between 1,000 and 19,000 yojanas below the surface of the southern continent. Each of these hells has a diameter of 10,000 yojanas.

Below this is the roof of Avici, which is 20,000 yojanas below the surface, and is itself 20,000 yojanas broad, wide, and deep, so that its floor is 40,000 yojanas from the level of the earth. The Abhidharma Kośa adds that according to some accounts all the hells, instead of being in tiers, are on a level. Furthermore, all the accounts agree that each hell possesses sixteen annexes, which makes the total number of hot hells into 136.

There was some difference of opinion ${ }^{1}$ as to whether the fiends who inflict torture on the damned are really sentient beings or soulless automata created by Karmic power. The consensus of opinion was in favour of the latter theory, except for Yama, the king of the dead, before whom the dead appear, are judged, and their just punishment assigned. Some accounts state that the judgment of women is in the hands of his sister. In any case, Yama and his retinue are living beings born there as the result of a vow registered in the past. He has eighteen chief ministers and thousands of retainers. The position of Yama's court is also disputed. The Abhidharma Kośa states it to be 500 yojanas under the earth. Others claim that it is on the circumference of the globe.

The Kāma Dhātu. The Other Divisions.

Above the hells come the realms of (1) the Pretas or ghouls, who, according to the Abhidharma Kośa, have their head- 
quarters in the underground palace of Yama, but also inhabit cemeteries, and dark caverns, etc. (2) The animals of all kinds found all over the surface of the earth, and in the air, but most of all, so say the commentaries, in the water. Mankind, who inhabit the four great continents and the eight sub-continents. (4) The Asuras, ${ }^{1}$ the inferior deities, frequently represented as opposed to the superior deities, who occasionally appear upon the earth, but who for the most part inhabit the lower regions of Meru, and the seven rocky circles. (5) The Devas who inhabit the upper regions of Meru, and the heavens immediately above its summit.

The Deva heavens are of sufficient importance to merit separate attention.

(a) The Heaven of the Four Great Kings. ${ }^{2}$-The inhabitants of the lowest of the six deva heavens, the Catur-mahäräjika Heaven, inhabit the mansions of the sun and the moon, and the summits of the seven interior rocky circles, but their headquarters are the four tiers or excrescences on the lower half of Mount Meru. The lowest of these tiers is 10,000 yojanas above sea-level, the second 10,000 above the first, the third 10,000 above the second, and the fourth 10,000 yojanas above the third, so that the highest point of this realm is 40,000 yojanas above sea-level, or just half the total height of the mountain. These four tiers protrude from the side of Meru 16,000, 8,000, 4,000, and 2,000 yojanas respectively. In the first tier dwell the Yakșas, known as the Karoțapāni, or the firm-handed. In the second the Mālādhāras or the holders of crowns. In the third, the Sadāmādas, or the ever-intoxicated (with pride), and in the fourth and highest tier the Four Great Kings themselves and their immediate retainers. The four great kings are the guardians of the four

1 See especially D.A., p. $103 b$.

${ }^{2}$ A.K. 11-10a; N.A. 31-14a; F.T. 32-18a; Dt., p. 104b; Y.B. 4-4a. For the South, M.B. 24. 
quarters, and so one is placed on each of the four sides of Meru. Their names ${ }^{1}$ are :-

(1) Dhrtarāṣtra, guardian of the east; (2) Virüdhaka, guardian of the south ; (3) Virūpākșa, guardian of the west; (4) Vaiśravana, guardian of the north. The retainers of the first are Gandharvas, of the second Kumbhāndas, of the third Nāgas, and of the fourth Yakșas.

Each of these four kings has ninety-one sons who share in the name, privileges, and duties of their parents, and help to guard the ten regions of space. Further, each king has eight all-powerful generals, who act as agents of the four kings and have charge of the lesser deities of the mountains, rivers, forests, etc., all over the world. The chief of these generals is Vaideha, who acts as the special protector of Bhikșus, and is frequently portrayed at the end of Chinese Sūtras as the symbol of guardianship against all evil. The Abhidharma Kośa adds that among all the Deva realms the inhabitants of this heaven are the most numerous.

(b) The Heaven of the thirty-three Gods, ${ }^{2}$ or the Trayastrimśa heaven, is the second heaven of the Deva-lokas. All traditions are in agreement that this heaven is placed on the summit of Meru, occupying the whole of the space thereon, each of whose sides is generally stated to be 80,000 yojanas long. At each of the four corners there is a peak 500 yojanas high, where reside the Vajrapāni Yakșas, who act as guardians of this heaven. In the middle of the flat summit table of Meru is the royal city of Sakra, the chief of the Devas. This city is called Sudarśana, the beautiful to see. Each side is 2,500 yojanas long, and its circumscribing wall of gold is $1 \frac{1}{2}$ yojanas high. The floor of this heaven is of a hundred colours. Nevertheless, it is as soft as cotton, following the foot as it ascends and descends. In the middle of this city is the palace of Sakra, called Vaijayanta. The length of each of its sides is 250 yojanas. On each of the four sides of the

1 M.Vy. 223.

${ }^{2}$ A.K. 11-10b ; F.T. 32-20a ; D.A., p. $105 a$; Y.B. 4-14b. 
jewelled city is a pleasure park with a magic lake. The names of these frequently described parks are : (1) Caitraratha, on the east; (2) Purusyaka, on the south; (3) Miśrakavana, on the west; and (4) Nandana, on the north. On the northeast of the city there is a magic tree 100 yojanas high, emitting a beautiful perfume; on the south-west is the meeting hall of the gods of this realm where they gather together to discuss the law.

(c) The other four Devalokas. ${ }^{1}$-The remaining heavens of the Kāma dhātu are :-

1. Yäma, 80,000 yojanas above the second heaven and 160,000 yojanas above sea-level. Here there is no division of day and night, it being perpetual day-time.

2. Tusita, 160,000 yojanas above the Yāma heaven, and 320,000 above sea-level, where reside the heavenly illuminating deities. who shed light upon all the world. This is a very popular heaven among the Buddhists, for here went Mahāmāyā, the mother of Gautama, on her death, and here reside the Bodhisattvas before their final incarnation on earth as Buddhas. For this reason Maitreya, the next Buddha, resides at present in this heaven.

3. Nirmānarati, 320,000 yojanas above the Tușita heaven, and 640,000 yojanas above sea-level. The name means the heaven of transforming pleasures, so called because subjective desires are at once transformed into objective pleasures, thoughts as well as wishes being creative forces.

4. Paranirmitavaśavarti, 640,000 yojanas above the preceding heaven, and 1,280,000 yojanas above sea-level. It is the heaven of the freedom of transformations, and the highest of the Kàma heavens. Here it is that a single look may generate new Karma. Strangely enough, either in this heaven or immediately above it is the abode of Māra, the Buddhist Satan, who is the king of lust and cupidity, and is therefore the ruler of the Kāma dhātu, or the realm of desire.

1 M.Vy. 219 ; A.K. $11-12 b$; N.A. $31-16 a$; D.A. $92 b$; M.B. 25 ; C.P. 139 ; Y.B. 4-14a. 
The Abhidharma Kośa states that there was a difference of opinion regarding the dimensions of these heavenly mansions. According to one opinion, Yāma and the others are four times the size of the Trāyastriṃsa heaven, while others state that each heaven is twice the size of the one immediately below it. Rūpa Dhātu.

Above the heavens of the Kāma dhātu, where both cupidity and form remain, are the heavens of the Rūpa dhātu, frequently called the Brahma heavens, where cupidity no longer has a place, but where the inhabitants still have bodies, and so shape or form (rūpa). These heavens are variously enumerated as sixteen, seventeen, and eighteen. In the Abhidharma Kośa, ${ }^{1}$ which gives the number as seventeen, the heavens are enumerated as follows:-

1. Brahmakāyika, the heaven of Brahma's retainers.

2. Brahmapurohita, the heaven of Brahma's ministers.

3. Mahäbrahma, the heaven of Brahma himself.

4. Parittäbha, the heaven of lesser light.

5. Apramānābha, the heaven of infinite light.

6. Abhāsvara, the heaven of universal light.

7. Parittaśubha, the heaven of lesser purity.

8. Apramānaśubha, the heaven of infinite purity.

9. Subhakrtsna, the heaven of universal purity.

10. Anabhraka, the cloudless heaven.

11. Punyaprasava, the heaven of fortunate birth.

12. Brhatphala, the heaven of great results.

13. Abrha, the passionless heaven.

14. Atapa, the heaven without heat or affliction.

15. Sudrisa, the heaven of perfect form.

16. Sudarśana, the heaven of perfect vision.

17. Akaniștha, the highest heaven.

Southern accounts ${ }^{2}$ generally agree in enumerating the Rüpa heavens as sixteen, agreeing on this point with the

1 8-2a, cf. M.Vy. 219 ; D.A., p. $92 b$.

2 M.B. 26, C.P. 138. 
Kaśmira Sarvāstivādins, though there are points of divergence on names. Mahayanists ${ }^{1}$ for the most part, and practically all schools in China and Japan, give the full number, eighteen.

In this connexion the Buddhist theory of Dbyāna must be taken into consideration, for the Dhyānas are intimately associated with the Rūpa heavens, and the various heavens are classified according to the Dhyanna to which they appertain. Dhyāna means meditation or contemplation, but later the word was used to indicate a special type of meditation, in which four or five states were distinguished.

When only four Dhyānas are spoken of, they are as follows : ${ }^{2}$ (1) supernatural ecstasy associated with vicāra and vitarka ; (2) ecstatic contemplation no longer associated with either vicāra or vitarka, or, in other words, where reasoning gives way to intuition; (3) contemplation where ecstasy gives way to serenity; (4) deep meditation where the mind becomes indifferent to pleasure and pain. According to the Abhidharma Kośa, ${ }^{3}$ the first three rūpa heavens are gained as the result of the practice of the first dhyāna, and so are called the First Dhyanna Heavens. In like manner, the next three are called the Second Dhyāna Heavens; the next three the Third Dhyāna Heavens; and the last eight the Fourth Dhyāna Heavens.

The division of the Dhyānas into five instead of four is frequently made in the later schools, more especially in those inclined to esotericism. ${ }^{4}$ In this case the second of the four Dhyānas, "Intuitive Meditation," is divided into two parts, the first corresponding more or less to the occidental "instinct", and the second to "spiritual perception not derived from intellect". In the schools which enumerate both five Dhyānas and eighteen rūpa heavens, the relation of the Dhyānas and the heavens is as follows: The first three to the first Dhyāna; the next three to the second Dhyāna;

1 Y.B. 4-14a.

3 8-2a, cf. also A.S.P. 2-7b.
2 M.Vy. 112, Y.B. 11-43a.

- But also in Neo. Stu. C.P. 141. 
the next three to the third Dhyanna; the next four to the fourth Dhyāna ; and the last five to the fifth Dhyāna. Associated with the five Dhyānas are the five Dhyāni Buddhas, the supreme lords of Nepalese and Tibetan Buddhism, as well as the so-called esoteric branch of Mahāyāna generally. These, however, as accepted by none of the three schools under consideration, may be ignored.

As regards the size of these various heavens, we find two principal accounts. According to one, the first Dhyāna heavens are in size the same as the earth; the heavens of the second Dhyāna are in size equal to a small chiliocosm; the heavens of the third Dhyāna to a middle chiliocosm; and the heavens of the fourth Dhyāna in size equal to a great chiliocosm. According to the other account, the heavens of the first, second, and third Dhyānas are respectively equal in size to a small, a middle, and a great chiliocosm, while the extent of the heavens of the fourth Dhyāna is measureless.

Arūpa Dhätu. ${ }^{1}$

Higher than the Rūpa Dhātu, or the realm of form, is the Arūpa Dhātu, or the realm of formlessness, in which the inhabitants have neither desire nor such a thing as a body, consciousness alone remaining. Nearly all the schools enumerate the heavens of this realm as follows :-

1. $\bar{A} k \bar{a} s \bar{a}$ nantyāyatana, the heaven of boundless space.

2. Vijñānanantyāyatana, the heaven of infinite consciousness.

3. Äkimcanyāyatana, the heaven of absolute non-existence.

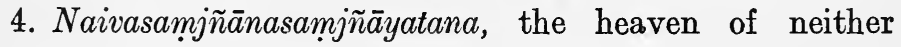
consciousness nor unconsciousness.

Rebirth in these realms is said to be due to meditation on the four immeasurables, one for each heaven. Yet, notwithstanding their many merits, rebirth in one of these abodes was deprecated, as the duration of life is so inconceivably long that progress to the supreme goal of Nirvāna is seriously

1 M.Vy. 221 ; M.B. 26 ; C.P. 139 ; A.K. 8-2a ; Y.B. 4-14a. 
delayed. In fact, rebirth here is one of the eight Akuśalas or evil moments, eight times of birth, not conducive to enlightenment.

\section{The Buddha Ksetras.}

So far, the Mahāyāna and Hīnayāna accounts of the various realms of existence have been more or less in agreement, but on one point there is wide divergence. We have already noticed that while the performance of good deeds will result in rebirth in one of the Devalokas or Brahmalokas, etc., yet as such a rebirth is frequently a hindrance rather than a help, one wonders where a man should strive to be reborn in order to reap the greatest advantage-where there is a place free from affliction and yet is one where spiritual progress may be made.

Practically all forms of Hinnayāna are silent on this point, but in Mahāyāna we find an attempted solution in the doctrine of the so-called Buddha Kșetras or Buddha lands, reference to which will be found in practically all the sutras of this school. The basic idea of this dogma seems to be that every man upon reaching supreme and perfect enlightenment acquires a spiritual realm, to which he repairs after death and in which he continues to instruct his Bodhisattvas and other persons who may be born there, leading them to supreme enlightenment for themselves. These manners of rebirth naturally appealed very strongly to the Mahāyānists, and consequently in many of their devotional writings we find the authors piously desirous that the merit which they may have acquired by instructing the world through their written works may secure for them at death rebirth in one of those lands.

As usual, there is great inconsistency in the various accounts and enumerations of these Buddha Kșetras, since every Buddha field is really so great and so large as to be co-existent with the universe, and yet at the same time there are as many Buddha fields as there have been Buddhas. In the earlier days of Mahāyāna a man endeavoured to be reborn in any 
Buddha land, or at least in the realm of the Buddha who took his especial fancy. As time went on, however, Mahāyāna became more monotheistic, particularly in its Chinese and Japanese phases, and the belief grew that there was but one supreme and universal Buddha, who included and overshadowed all the rest. Consequently, the Buddha land of this Buddha, whoever he happened to be, came to be the goal of ordinary ambition. Historically, we find that there were two monotheistic strains, which finally resulted in two different schools, in one of which the supreme being is known as Vairocana, and in the other Amitābha. Consequently, we find likewise two main lines of development in the Buddha Kșetra theory.

(a) Buddha Kșetras in the Vairocana schools.-The followers of Vairocana were for the most part the esotericists and occultists who were generally more concerned with the control of one's destinies in this life than in the world to come, so that the paradise doctrine of this school did not receive the same development as did the Amitābha paradise doctrine. Nevertheless, the Buddha Kșetra idea was not wholly neglected. In certain cases the ten or thirteen stages of Bodhisattvahood were symbolized as material heavens, in the highest of which dwelt Vairocana himself. Even more interesting are the thirteen stages of the path of progress of the righteous departed as taught in the esoteric school of China and Japan :-

1. Acala, where the soul remains for the first week after death.

2. Śäkyamuni, for the second week.

3. Mañjuśri, for the third week.

4. Samantabhadra, for the fourth week.

5. Kșitigarbha, for the fifth week.

6. Maitreya, for the sixth week.

7. Bhaișajaguru, for the seventh week.

8. Avalokiteśvara, for another hundred days.

9. Mahasthāmaprāpta, for another year. 
10. Amitäbha, for another three years.

11. Akșobhya, for another seven years.

12. $\bar{A} k \bar{a}$ śagarbha, and

13. Vairocana for ever.

(b) Buddha Kșetra of the Amitābha school.-Turning now to the other school, we find that the Amitäbha cult is based almost exclusively on rebirth in paradise through selfrenouncing adoration to Amitābha, so that among the followers of this school the Buddha Kșetra doctrine received very great development. Originally but one out of many equally important realms (the Avatamsaka Sūtra assigns to it a still lower position), it came gradually to assume pre-eminence among all the paradises, possibly because by chance it was placed in the west. The principal scriptural authorities for the doctrine are: (1) The larger Sukhāvatī-vyūha Sūtra, which, dealing with the past, tells how this marvellous land came to be created through the great vow of Dbarmakāra Bodhisattva, who later became Amitābha Buddha; the Amitāyur Dhyāna Sūtra, or the sūtra of the meditation upon Amitābha, which deals with the present, or how men should so conduct themselves as to secure rebirth in Amitābha's land; (3) the smaller Sukhāvatī-vyūha Sūtra, which deals with the future, i.e. the future condition of those who gain this Kșetra, and gives a long description of the great bliss that is to be found there. Apart from occasional mention elsewhere, two works in the Sāstra literature of India deal more particularly with the doctrine. One of these is a Bodhisattvabhumi, or discourse on the stages of a Bodhisattva, ascribed to Nāgärjuna, the other a commentary on the Sukhāvati-vyūha called the Amitāyursütropadesa, ascribed to Vasubandhu. In both of these works the purely material side of the paradise doctrine is retained, and Amitābha is still but a single and semi-historical Buddha, and his paradise but a single even if important Buddha Kșetra. The rather monotonous tone of the descriptions of delights to be found in these various works may be seen from the 
translation of the three Sukhāvati Sūtras in the sacred bookš of the East.

\section{THE WORLD OF SENTIENT BEINGS ${ }^{1}$}

\section{Classification of Sentient Beings.}

We have already seen the geographical position of the various divisions of the three dhätus. We must now study the persons who inhabit these realms.

First of all in this connexion must we give the principal categories into which sentient beings are divided. These are: (1) the five or six gatis, or destinies; (2) the seven vijñana sthitis, or bases of consciousness ; (3) the nine abodes of sentiency.

The Five or Six Gatis.-This is the most important of all Buddhist classifications of sentient beings, and is the basis of the various Buddhist wheels of life or charts of existence. The five-fold division is made by most branches of Hinayāna, the six-fold division by a few branches of Hinayāna and most branches of Mahāyāna. The five gatis ${ }^{2}$ are :-

1. The inhabitants of the Narakas or hells.

2. Preta, ghouls, goblins, or demons.

3. Animals.

4. Mankind.

5. Devas or gods.

Where a sixth gati is added, it consists of the Asurastitanic, demonaic monsters, somewhat akin to the Devas, with whom, however, they are constantly at war. Those who defend the five gati theory never doubted the existence of the Asuras. They were merely not of sufficient importance to be given a place as a separate destiny, and were grouped either with the pretas or animals or both. Sentient beings when they die are reborn into one or the other of these five destinies. There is no other form of existence possible. The geographical 
relationship between the three dhätus and the five gatis has already been given.

The Seven Vijñana Sthitis.-The three dhātu and the five gatis are likewise divided into those realms which do and those which do not support consciousness. Those which do are divided in a seven-fold manner, forming the seven Vijñāna sthitis, which are ${ }^{1}$ :-

1. Those realms in which the bodies as well as the thoughts of the inhabitants differ from one another. This includes the whole of the Kāma dhātu and also the first Dhyāna heavens of the Rūpa dhātu, except during the period of creation.

2. Those realms in which the bodies are diverse but the thoughts uniform. This consists of the first Dhyāna heavens during the period of creation, inasmuch as at that time all are filled with the single thought, "We have been created by Brahma."

3. Those realms in which the bodies are the same but the thoughts diverse. This consists of Ābhāsvara and the other heavens of the second Dhyāna.

4. Those realms in which both the bodies and thoughts of the inhabitants are uniform. This consists of the heavens of the third Dhyāna.

$5,6,7$. The last three vijñanna sthitis consist of the three lower divisions of the Arūpa dhātu.

The three evil places (hells, pretas, and animals), the heavens of the fourth Dhyāna, as well as the fourth heaven of the Arūpa dhātu, are not classed as vijñāna sthitis, inasmuch as life and conditions therein do not serve as stimuli or supports (sthiti) of consciousness.

The Nine Abodes of Sentiency. ${ }^{2}$ - The nine so-called abodes of sentient beings consist of the above seven vijñāna sthitis, with the addition of the fourth, Arūpa dhātu, and the unconscious deities of the fourth Dhyāna heavens. These realms are so called because sentient beings exist there willingly, or, in other words, they are suitable abodes for

1 A.K. 8-7a.

${ }^{2}$ M.Vy. 169, A.K. 8-9b. 
living beings. The evil realms are not included in this category, since they may be likened to prisons rather than abodes. Nor, for somewhat more metaphysical reasons, are the other sections of the fourth Dhyanna included.

The Four Kinds of Birth, and the Stages of the Fotus.Sentient beings revolve in an eternal circle through the five gatis. Dying in one gati, they are reborn in another. There are four methods whereby this rebirth may take place. ${ }^{1}$ They are : (1) Birth from an egg; (2) birth from a womb; birth from slime; (4) apparitional birth. Instances of egg birth are various kinds of birds ; of womb birth, such animals as the horse, cow, dog, etc.; of slime birth are mosquitoes, flies, and various other insects. Apparitional birth is so called because it is miraculous, without visible support, and with all the organs instantaneously perfectly formed. Of such birth are the inhabitants of the various heavens and hells. The normal method of birth for man is from the womb, but occasionally the other three methods occur. The animal gati also includes all four methods of birth. Three have already been mentioned. Apparitional birth takes place in the case of dragons, etc. All the denizens of the heavens and hells have no other method of birth than apparitional. Pretas are sometimes born from the womb, sometimes apparitionally. Of all the various kinds of birth, apparitional birth is the best, but Buddhas and Bodhisattvas receive womb birth that their humanity may be complete.

In the case of womb birth, the fotus goes through a regular order of development. Five principal stages of embryo development are usually enumerated. These are ${ }^{2}$ : (1) Kalala ; (2) Arbuda ; (3) Pesi ; (4) Ghana ; (5) Praśakha.

The Doctrine of the Intermediate Existence. ${ }^{3}$-There was a good deal of difference of opinion among the various Buddhist sects as to whether or not at death a being passed at once

1 M.Vy. 168; A.K. 8-11b.

2 A.K. 9-8b.

3 Long discussion, A.K. 8-13b ff. 
into his new existence, or whether there is a short period of existence in an intermediate state. The Mahāsānghikas denied the doctrine of the intermediate existence, while the Sarvāstivādins and most of the later schools accepted the doctrine, which later was worked out in some detail. The following points concerning the Sarvāstivādin doctrine on the subject may be of interest.

The being in the intermediate state is possessed of a definite body, but of a very subtile kind. In shape it is of the same kind as his future existence. Thus, in the case of a person destined to be born as a man. The intermediate body is of the same size as a child 5 or 6 years of age. The organs are always complete. The intermediate bodies of those destined for the Rūpa dhātu are possessed of clothes as are Bodhisattvas and some others, but the majority of beings destined to the Kāma dhātu are nude. Such beings can see other beings of the same class, in certain cases of the classes below them. They are possessed of certain magic powers, such as being able to pass through space, and on the death of the previous person the new intermediate body is attracted to the place of its new birth through desire, going there miraculously. Its destiny is fixed. The body destined for human birth never develops into another existence. It partakes of no solid food, but receives its sustenance from smell. The duration of its existence is indefinite, existing until such time as the new body is prepared for habitation, though ordinarily, say some, it lives for only one week or seven weeks. If a male it enters the right side of the mother's womb and faces the back, if a female it enters the left side of the womb and faces front. In the case of twins the child born last is the oldest.

Size and Duration of Life of the Various Realms. ${ }^{1-A}$-A word must be said concerning the nature of life in each of the various gati through which sentient beings pass. First as regards their stature. No exact figures are given for the destinies lower

1 A.K. 11-15b ff. ; N.A. 31-21 $a$ ff. ; C.P. 142 ; Y.B. 4-14a and 4-14b. 
than man. In the southern continent (Jambüdvipa) the size of men varies from time to time, but the average size, at least for the present, is $3 \frac{1}{2}$ or 4 hasta or cubits. For the eastern continent the average size is 8 cubits, for the western continent 16 cubits, and for the northern continent 32 . In the heavens of the Kāma dhātu statures are as follows :-

1. Heaven of the four Great Kings $\quad \frac{1}{4}$ krośa.

2. Heaven of the thirty-three Gods $\quad \frac{1}{2}$ krośa.

3. Yāma heaven . . . . $\frac{3}{4}$ krośa.

4. Tuṣita heaven . . . . 1 krośa.

5. Nirmāṇarati heaven . . . $1 \frac{1}{4}$ krośas.

6. The highest Kāma dhātu heaven . $1 \frac{1}{2}$ krośas.

In the Rūpa dhātu statures are as follows: In the first $\frac{1}{2}$ yojana, in the second 1 yojana, in the third $1 \frac{1}{2}$ yojanas, in the fourth 2 yojanas, in the fifth 4 yojanas, and so on, doubling (except for Anabhrakas) so that the highest has 16,000 yojanas for its average stature. In the Arūpa dhātu the inhabitants have, of course, no bodies.

As regards duration of life there is no constant for the southern continent, as it varies between a asamkhya and ten years; for the eastern continent, 250 years ; for the western continent, 500 years; for the northern continent, 1,000 years.

In the first Devaloka, the heaven of the four great kings, a day and night is equal to 50 human years. Their months consist of thirty such days, their year twelve such months, and the average duration of life is five hundred such years. In the second heaven a day and night are equal to a hundred human years, a month has thirty such days, a year twelve such months, and the inhabitants live for a thousand such years. In each of the higher realms the numbers are doubled. Thus, in the Yāma heaven a day and night are equal to 200 human years, a month contains thirty such days, a year twelve such months, and the inhabitants live for 2,000 such years. Since there is no sun nor moon in these realms, day 
and night are marked by the opening and closing of sacred lotuses.

In the Rūpa dhātus there is neither day nor night, and the duration of life is measured by Kalpas. In the first the average duration of life is one middle kalpa, or $\frac{1}{4}$ a mahākalpa; in the second 2 middle kalpas, or $\frac{1}{2}$ a mahākalpa ; in the third 1 kalpa ; in the fourth 2 kalpas; in the fifth 4 kalpas; and so on, doubling in such a way that the number of yojanas for average height is the same as the number of kalpas, the highest being 16,000 kalpas.

In the Arūpa dhātu, or realm of Formlessness, we have even greater figures. In the first the duration of life is 20,000 kalpas, in the second 40,000 kalpas, in the third 60,000 kalpas, and in the fourth 80,000 kalpas.

Finally, the duration of life in the three evil gatis (animals, pretas, and hells) must be taken into consideration. Animals have no fixed duration of life. Some live only for a moment and some for centuries. The greatest span of life is enjoyed by a species of dragon which lives for one middle kalpa. The day of a preta is equal to a human month. Thirty such days make a preta month, twelve such months a preta year, and a preta lives for 500 such years. No exact figures are given for any of the hells, save the hot hells. The whole duration of life of the heaven of the four great kings is equal to a night and a day of Samjiva, and the inhabitants live for 500 years of such days. The duration of life in the next six hells corresponds in a similar manner to life in the remaining five deva heavens. In the seventh hell the duration of life is half a middle kalpa, and in Avici the duration of life is a whole middle kalpa.

Nature of Life in other Realms. ${ }^{1-A}$ few out of the many other such details of life in the other gatis as found in the Buddhist books are as follows : Every form of sentient being is under the necessity of taking food, though there are four

1 Cf. especially A.K. 11-13a ff. ; Y.B. 4-14b ff. 
kinds of food: ${ }^{1}$ (1) corruptible food, i.e. food capable of being digested, which is the food used by all forms of men and by the Devas of the six Käma heavens; (2) food that is partaken by contact only, which appertains to the upper divisions of the Käma heavens and the lower regions of the Rūpa dhätu ; (3) food that is partaken of by contemplation, as is the case with the upper regions of the Rūpa dhätu; (4) food that is partaken of by the knowledge of it. This applies only to the inhabitants of the Arūpa dhātu.

In all of the heavens save those of the Arūpa dhātu clothes are used, though sex remains only in the heavens of the Kāma dhātu. There are five ways of satisfying sexual desire : ${ }^{2}$ (1) by copulation; (2) by embracing; (3) by the holding of hands; (4) by laughing or smiling at one another ; (5) by looking at one another. Living in contact with the earth, the inhabitants of the heaven of the four great kings and also of the heaven of the thirty-three gods, unite by copulation. In the Yāma heaven a single embrace produces a new being. In the Tusita heaven the mutual holding of hands suffices. In the Nirmānarati heaven smiling, and in the highest Kāma heaven a single glance constitutes sexual union. Birth (which is apparitional in all the heavens) takes place in the Kāma heavens as follows: Shortly before a deva is born one of the devis finds a flower in her hand. She knows by this fact that a child is to be born to her, and accordingly after seven days birth takes place, often, however, by suddenly appearing on her knees. At the time of their birth, the children are as if five to ten years of age. There then appears spontaneously a precious vessel filled with divine food, partaking of which the new-born being grows in size like the rest of the devas, while magic trees provide them with necessary garments. The inhabitants of the Rūpa and Arūpa dhätus are born fully grown and without the aid of any sort of parent, and in the Rūpa dhātu are born fully clothed. We are also informed that the gods of all three realms speak

${ }^{1}$ M.Vy. 169.

2 A.K. 11-12b; N.A. 31-16a. 
only the Āryan language, a sort of heavenly Sanskrit, which moreover they speak correctly without having to learn it.

In the Kāma dhātu there are three ways of enjoying pleasurable objects, the first of which applies to men and the four lower deva lokas, and is by ruling over and enjoying the sense pleasures they find around them. The second, which applies to the fifth deva loka, by creating pleasurable objects and then ruling over and enjoying those things which they themselves have created. The third, which applies only to the sixth deva loka, is by ruling over and enjoying the sense objects especially created for their enjoyment by others.

Even in the most pleasurable regions (apart from Sukhāvatī) life must come to an end, and the devas must die here to be born elsewhere. As they begin to grow old five signs of decadence begin to appear. These are : (1) The flowers upon their heads begin to decay; (2) their eyes grow dim and move uneasily in fear of the change which they know must come ; (3) the lustre of their bodies begins to fade ; (4) perspiration begins to exude from under their arms; (5) they listlessly absent themselves from their proper places.

In the various Buddha kṣetras the pleasures are even greater and more lasting, but of a less sensual nature. Most of the pleasure is of a spiritual nature, and consists of listening to the holy law. According to the older schools of Buddhism, these Buddha ksetras themselves are not permanent and life therein is only the preparation for Nirvāna or Buddhahood, but in the Shin sect of Japan rebirth into Sukhāvati is itself the highest goal, and is final and complete happiness. 


\section{PART II \\ COSMIC ANALYSIS}

\section{Subjective and Objective Classification.}

We now come to the consideration of the ultimate elements into which the Buddhists thought the universe could be decomposed-a subject which promises to be of greater interest. Here, at the very outset, we are faced with a very curious situation, for we find a two-fold analysis of the universe, one subjective and the other objective. In the former instance the nature of any one personality is examined, and by a process of analysis the seemingly unified personality is broken up into a number of component parts, which are ultimate or elemental, and since every personality is a microcosm closely corresponding to the macrocosm it follows that the component parts of the personality are also the component parts of the universe.

The objective classification is merely a re-arrangement of these component factors in a more scientific way, i.e. by examining the whole universe, irrespective of any one personality. It follows from this that the objective and subjective classifications are mutually inclusive, and that the difference between them is merely one of standpoint.

In point of fact the origin of the two categories is due to the peculiar nature of the Buddhist historical development. Primitive Buddhism was founded upon an agnostic basis, ${ }^{1}$ certainly as regards the external world. The Buddha declined to state whether it was infinite or finite, whether it is eternal or non-eternal. Consequently, for primitive Buddhism a complete list of the elements of being, approached from an objective point of view, was impossible.

Nevertheless, a certain amount of subjective analysis was permitted, and, in fact, encouraged. In order to eliminate

1 Cf. especially the agnostic passages from the Sūtra Pițaka collected by Warren in his B. in Trans., chap. 2. 
the belief in the àtman as taught by the Upanișads, the Buddha is said to have stated that the personality is not a unit, but a compound of various factors, such as the material body, consciousness, feeling, ideas, volitions, etc. In the early days little further analysis seems to have been attempted. But this was sufficient start for the Indian mind, always given to analytical subdivisions. Each of the main groups became many times divided, until a very complex chart of the factors of life was eventually tabulated.

Once this had been done, it is easy to understand how the next stage, the re-grouping of these component parts from the objective point of view, came to be undertaken. The early agnostic position of primitive Buddhism was soon neglected, 1 and, the categories already enumerated including all forms of life and all aspects of the external universe, it soon became obvious that it was more logical to re-arrange the categories in such a way as to form a complete philosophic analysis of the factors of being.

We see, therefore, that the subjective analysis was earlier and less systematic than the objective analysis, and that subsequently the latter tended, as more logical, to overshadow the forme. Having been embodied in the sūtras, however, the subjective classification was never lost sight of, and we find that occasionally the later philosophers, including Buddhaghosa, preferred to revert to the earlier grouping, although acknowledging the validity of the objective classification.

\section{(A) The Subjective Classifiuation}

Owing to its priority in point of time, and also to its greater simplicity, it is advisable to consider the subjective classification first. This consists of three categories, viz. ${ }^{2}$ :-

1 See e.g. f. 30 of A.K., where some of the older agnostic passages concerning the soul are used by Vasubandhu to deny its existence.

2 C.P. gives these categories but scant attention, but they are enumerated pp. 182-3. An excellent discussion of cach category from the Pali point of view will be found in Mrs. Rhys Davids' Buddhist Psychology, where original sources are quoted. 
1. The Five Skandhas.

2. The Twelve Áyatanas.

3. The Eighteen Dhätus.

In the present instance it is more convenient to consider the five skandhas as one division and the twelve ayyatanas and the eighteen dhātus as a second division. ${ }^{1}$

\section{The Five Skandhas}

\section{General Discussion.}

The five skandhas constitute the component parts of a personality, though, certainly in later Buddhism, they are not ultimate factors, inasmuch as each of them is subject to subdivision. It is probable that the very name implies that each of them was considered a complex group rather than a unit, for the word means heap, collection, group. Vasubandhu (A.K. 1-14b) cites the following passage from the sūtras: "All things possessed of form, whether past, present, or future, whether internal or external, whether coarse or fine, whether mean or great, whether distant or near-all such things constitute one skandha, called the rūpa skandha.".

All the ultimate factors are classified into five groups or skandhas, and these five groups constitute the personality. This doctrine of the five skandhas is undoubtedly very old. Frequent mention is made of them in the suttras, where they are chiefly cited in disproof of the attman theory. The soul (a)tman) is not, nor is it the possessor of, the body, feelings, ideation, etc. In fact, there is no soul at all, but the personality consists of these groups and nothing more.

Nowhere in the sūtras is there a categorical or logical definition of the five skandhas, and it would seem as if each of the terms taken separately formed part of the common property of contemporary Indian thought, and that the only

1 For Sarvāstivädins see especially A.K., the whole of the first and second fasc. ; Sang. Par. 6-1 $a$; D.Sk., f. 17 for indriyas, f. 18 for àyatanas, and f. 19 for skandhas. For Yogācārins see especially P.Sk. and P.Sk.Vai.; Ab. Sam. San., 1-1 b ff. V. M. S., like C. P., pays little attention to the subjective classification. 
originality displayed by Buddhism was the doctrine that these skandhas and nothing more constituted the personality.

Unfortunately, for us the names of the five skandhas are not so illuminating as they seem to have been to the ancient Indians, and we find in the Occident a wide variety of terms used to translate them. The names and arrangement of the skandhas is almost invariably as follows :-
1. Rūpa.
3. Saṃjñā.
2. Vedanā.
4. Saṃskāra.

\section{Vijñāna.}

1. Rūpa, literally form or shape (sometimes colour), corresponds roughly to our matter, and in the personality implies the physical body. Among the many other definitions are ruppati (= whence rūpa), a most difficult word to translate, but which implies "subject to transformation", " affected", "disturbed", " disintegrating", " modified" (A.K. 1-10a).

The other definition, more in accord with our own ideas on the subject, is " that which resists" or " impenetrable".

Primitive Buddhism gives no definite subdivision of this skandha, other than that stated in the verse quoted above, but we know that the term rūpa referred to the matter constituting our own and other bodies, as well as inanimate matter. An enumeration of the thirty-two parts of the body is frequently given, of which the five sense organs are the most important, while external matter is also given a five-fold classification (corresponding to the five sense organs). We know, moreover, that all matter, whether internal or external, was supposed to be derived from the four elements, earth, water, fire, and air, which constitute the four ultimate states of matter. ${ }^{1}$

The Sthaviravādins subdivided matter a little more systematically. $^{2}$ Four divisions were ultimate or non-

1 Cf. the famous Keraddha sūtra in D.N. (D.B. 1-276), corresponding to D.A. $81 a$.

2 For authorities on these and the following statements see the list given under objective analysis below. 
derived, while there were twenty-three or twenty-four factors derived from the four elements. These and all the following subdivisions will be considered at length when we come to deal with the objective analysis of the universe. The whole of the classical metaphysical literature of this school, as well as Buddhaghosa and the Abhi. Sang. (C.P.), follow the sūtras in ignoring the doctrine of paramānu or atoms, but in modern times the atomic theory seems to have been adopted to explain the older doctrines.

The Sarvāstivādins accepted the atomic theory (as we shall see hereafter), and the idea of the four ultimate elements from which are derived eleven fundamental material factors, a somewhat more systematic list than that of the Sthaviravādins.

The Yogācārins, being idealists, thought that all matter is but the creation of the mind. Nevertheless, from the relative point of view, they followed the Sarvāstivādins very closely and accepted the four elements and the eleven derivatives (though the Yogācārin eleventh factor differs from that of the Sarvāstivādin). The early Yogācārin philosophers, such as Asanga and Vasubandhu, likewise accepted the atomic theory, but this was denied by later thinkers such as Dignāga and Dharmapāla as being inconsistent with idealism.

2. Vedan $\bar{a}$, the first of the four immaterial skandhas, is sometimes translated sensation, but careful study of the texts shows that it corresponds more closely to our own term feeling, for, in the first place, sensation in the sense of awareness is not Vedanā but Vijñāna, and, secondly, the fundamental division of Vedanā into pleasant, unpleasant, and neutral, or sometimes into pleasant, unpleasant, joyful, sorrowful, and neutral (the first two physical, the next two mental, the last both), shows that the hedonistic side of Vedana is emphasized. The fact that it is correlated with the sense organs (thereby giving it a six-fold classification) shows that it may be more adequately defined as "sense feeling occasioned by sense impressions", which is almost 
word for word the definition given it by Vasubandhu (A.K. 1-11b).

3. Samj $\tilde{n} \bar{a}$ is sometimes rendered "perception" and sometimes "conception". That it is not mere sense perception is, I think, clear, when Saṃjñā is compared with Vijñāna. The perceptual side seems to be more emphasized by the Pāli or Sthaviravādin commentaries, as when the Vibhanga, to give Mrs. Rhys Davids' translation, ${ }^{1}$ divides Samjuñā into (1) cognitive assimilation upon the occasion of sense, and (2) cognitive assimilation on the occasion of naming.

The Sarvāstivādins and the Yogācārins, on the other hand, emphasized the conceptual aspect. Vasubandhu (A.K. 1-11b) defines it as "the grasping of the differences of characteristics", and, again, "Samjuñā skandha has for its essence the grasping of images, i.e. it seizes hold of the attributes, blue or yellow, long or short, male or female, pleasant or unpleasant, antipathetic and sympathetic, etc." Personally, I favour the term "ideation" as a translation of Samjñ̄ā, and Mrs. Rhys Davids tells me that this will also cover the Pāli use of the term.

The correlation of Samjuña with the sense organs is also seen by its division into six categories, as in the case of Vedanā.

4. Samskāra.-Unquestionably, the most difficult term to explain is Sampskāra, and a large number of different renderings have been given, ranging from Spence Hardy's " conscience ", which is certainly wrong, to Professor Rhys Davids' "confections", which is perhaps the most correct etymologically, though personally I should prefer "coefficients". In point of fact, however, Saṃskāra early became associated with Karma, or action, as may be seen by its position in the Pratitya Samutpāda. It has thus been rendered into Chinese (行, to do, to perform), and in the Saṃukta Āgama it is said "all creatively active Sāsrava 
samskṛta dharmas are called the Saṃskāra-upādānaskandha" (S.A. f. 13).

In many of the sūtras some attempt seems to have been made to limit Samskāra to volition (Cetana - volitional mentation). Thus the Samyukta Āgama (op. cit.) says: "The group of six volitions (corresponding to the six sense organs) constitutes Saṃskāra skandha" (also quoted by A.K. 1-11a).

The definition of Samskāra as volition would have rounded off the Buddhist list of the five skandhas very well, but as psychological analysis continued, and further factors in the mental process were formulated, a place had to be made for them in the classification of the factors of the personality. Here there was a difficulty. The later Buddhists dared not add to the five-fold classification which they believed to have been laid down by the founder, so that the newly postulated factors had to be arranged somewhere inside the five already existing skandhas. The most convenient dumping ground was found to be Sampskāra, which thus became a weird medley of otherwise unclassified mental factors. Thus Mrs. Rhys Davids (Bud. Psy., 51), speaking of this matter, says: "The constructive aspect (of this skandha) was reserved for ... volition. The other fifty-one factors (of the Pāli enumeration) are rather co-efficients of any conscious state than preeminently active or constructive functionings."

Vasubandhu feels that an apology is needed for including this additional material, though his excuse is rather lame. He says (A.K. 1-11b) that the reason the Buddha stated that Sampkāra skandha consists only of the six-fold Cetana is because this factor is the most important, since Samskāra means creative activity, and in Cetana this attribute is more predominant than in the other factors. Nevertheless, the other factors must not be excluded, "for if this were done the remaining Caitasikas, and Citta Viprayukta dharmas would not be included in any of the skandhas, and consequently they would be independent of suffering and the cause of 
suffering, and hence could not be cut off and could not be known. For, as the Blessed One has said, "If a single thing be not analysed, or remain unknown, I say that it is impossible to attain the end of suffering ..." Consequently, all samskrta activities not included in the other four skandhas are placed inside the Samskāra skandha.

Samskāra thus came to be used as a term denoting all the mental concomitants which are at any time associated with the arising of Vijñāna or consciousness. Consequently, since Vedanā and Saṃjñā come under this category, they also were enumerated a part of Samskāra, so that from the absolute point of view the five categories were reduced to three, viz. :-

(1) The Body.

(2) Mental properties, or concomitants of consciousness.

(3) Consciousness.

Nevertheless, respect for tradition prevented the older and clumsier five-fold classification being disregarded, so that we find the later commentaries trying to explain why Vedanā and Saṃjñā are included in Samskāra and yet also listed as separate skandhas. Vasubandhu has the following remarks on the subject (A.K. 1-16b): "Among the Caitasikas, Vedanā and Saṃjñā are considered separate skandhas because they serve as causes of pugnacity and of the wheel of birth and death, and because of the due order of their functioning. There are two bases of pugnacity. One is the expression of various desires, the other is the expression of various opinions. Vedanā and Saṃjñā act respectively as their predominating cause. Owing to the emotions (Vedanā) all the desires are made manifest. Owing to erroneous ideation (Samjjñā) all theories are made manifest. Both birth and death have Vedanā and Samjuñā as their principal causes, since the wheel of birth and death is set rolling owing to man's enslavement to the emotions and his attachment to erroneous theories. For these two reasons and because of the due order of their causal functioning, to be explained 
hereafter, Vedanā and Samjuñā are considered separate skandhas."

A word must be said concerning the subdivision of Samskāra. Apart from Cetana, which is specifically mentioned, many of the mental properties later included in this skandha are found separately enumerated in the sütra Pițaka, but no attempt seems to have been made to give a detailed or definite categorization.

In the Hinayāna Abhidharma period, elaborate charts of the Samskāras were compiled, ${ }^{1}$ the individual items consisting of the various mental properties casually mentioned in the sūtras, together with a certain number of factors deduced by individual introspection. It is to be regretted that so many are of the former type, since the use of terms is very vague in the sūtras and many psychological terms were but as obiter dicta, which were later enshrined in the Abhidharma works as final revelations of ultimate truth. The right of such items to be considered ultimate factors was therefore very acutely defended by minds able to formulate a far more scientific analysis of mental components.

The Sthaviravādins enumerated fifty-two such Saṃskāras. ${ }^{2}$ Among the Sarvāstivādins there was much variation in number for some considerable time, and it was not until the time of Vasubandhu that the number was definitely put at forty-six, which afterwards remained the standard figure. The Yogācārins hovered between fifty-one, fifty-two, and fifty-three, but fifty-one was eventually considered the orthodox figure. ${ }^{3}$ Incidentally, the Yogācārin fifty-one is by no means in agreement with the fifty-two Caitasikas of the Sthaviravādins.

5. Vijñana, the last of the skandhas, is usually translated "consciousness" or " cognition". This definition is quite in accord with all the commentaries, and many references to

1 Cf. e.g. Dham. San., part ii (Book I of R.D. trans.).

2 At least after Buddhaghosa, see Expositor.

${ }^{3}$ Y.Bh. $=53$; Ab. San. $=55$; A.V.P.-P.Sk.-S.dh. $=51$; and V.M.S. 
the term shows that it denoted for the Buddhists merely " awareness" in the broadest sense of the term. Hence it is associated with much which we should call sensation, save that it lacks the hedonistic element which is given to Vedanā. Again, it is associated with the perceptual aspect of Sampjñā, save that it is ampler in its scope, implying not merely the "seeing" of a thing but the full awareness of it, or the absorption of the image into the conscious mind.

The distinction between Vijñāna and Saṃskāra, particularly in the later use of the latter term, is that Vijñana is "consciousness" or the "various aspects of consciousness", and Sampkāra is the contents or functional phases of consciousness. Thus the awareness of a visual object implies attention (manașkāra), sensation or contact (sparśa), etc. And further, as Vedanā and Samjjñā are considered as Saṃskāras, we find that even these are phases or functions of consciousness rather than independent realities.

That Vijñana involves both the sensatory and ideation aspects of consciousness can be seen from the minimum six-fold classification of Vijñana common to all forms of Buddhism, however many additional aspects may be added. The six divisions consist of five kinds of consciousness dependent respectively upon the five sense organs, and one type of consciousness dependent upon the operation of the mind (manas). This last possesses several functions peculiar to itself, such as intellection, reasoning, and memory.

The most important addition to this six-fold category was made by the Yogācārin, who added two more, making eight in all. To this, certain other authorities, chiefly Chinese, have added a ninth. ${ }^{1}$

Among the Sthaviravādins, in addition to the six-fold group, Vijñāna was also classified in a different way under eighty-nine different heads. This arrangement is peculiar to this school, and had no effect upon later philosophic speculation.

1 Cf. sect. on Vij. in 四 教義 and 五教章. 
Concluding Remarks.

Turning now from the skandhas taken separately, let us consider them for a moment as a whole. To us there seems little logical basis for this five-fold division of the personality, and it would seem as if the Buddhists themselves were struck by its pragmatic nature, and that the non-material part of the personality was arbitrarily broken up into four co-ordinate parts chiefly in order to emphasize the complex, compound nature of the mind.

Nevertheless, the five-fold division is not altogether lacking in psychological insight, and, more particularly if the volitional aspect of Samskāra had been retained, we should have had a certain correspondence between the east and those western psychologists who divide the mind into (1) feeling, (2) reason, and (3) volition, corresponding respectively to Vedanā, Saṃjñā, and Saṃskāra, which, with Vijñāna, consciousness considered as a whole, and Rūpa, the body, would give us the following classification :-

1. The body, including sense organs.

2. Consciousness, or awareness, reception of the sense impressions transmitted by the sense organs.

3. Resultant feeling of like or dislike of these impressions.

4. Ideation or the formation of mental images concerning the nature of the external world from which sense impressions are derived, including the classification (naming) of those objects which are pleasant and those which are unpleasant.

5. Volition oi will with respect to choosing as far as possible those objects which are pleasant and those which are unpleasant. Later, as we have seen, mental activities other than volition were added, but were placed in the same category.

It was only the early mistranslation of the names of the five skandhas which prevented it being seen that some such 
scheme was in the mind of the early Buddhist philosophers. In this connexion, and more or less in defence of this position, one or two points deserve attention.

Vijñanna follows immediately upon the interaction of the sense organs and sense object, and without the intermediary action of a separate faculty such as Vedanā or Samjiña. This is obvious from the frequently repeated texts to the effect that "as a result of visible object and organs of sight visual consciousness comes into being", and also from the correlation of the sixth sense objects, six sense organs, and six aspects of consciousness to form the eighteen dhätus or factors of existence. From this fact, the sensatory aspect of Vijñāna becomes obvious, a fact that is sometimes overlooked, owing to Vijñāna's place among the skandhas, Vedanā and Saṃjñā intervening between it and Rūpa, the body. We find, however, that while retaining the traditional order in the bare enumeration of the skandhas, both Buddhaghosa and Nāgārjuna give their exposition of Vijñāna immediately after their explanation of Rūpa.

Vedanā, Saṃjñā, and Saṃskāra do not first arise as a result of bodily functioning and then produce Vijñāna, for it is expressly said that these cannot exist independent of consciousness. ${ }^{1}$ Rather are they accessories, even though necessary accessories of consciousness which arise simultaneously with it. Since they are thus but concomitant phases dependent upon Vijñāna, which arises directly from the operations of the sense objects and sense organs, the later Buddhists grouped them together as Caitasikas or " mentals", and the Sthaviravādins and Sarvāstivādins gave them, in their external classification of the universe, the following invariable order :-
1. Rūpa.
2. Citta or Vijñāna.
3. Caitasikas.

1 A.K. 4-3a; M.Sh., p. 173. 
(a) Vedanā.

(b) Saṃjñā.

(c) The remaining Saṃskāras.

While, however, the Caitasikas are mental properties owing to their existence to Citta or Vijñāna, and hence cannot arise before the latter, yet, on the other hand, pure Citta devoid of all of these Caitasikas cannot arise. So that it is said that the origination of Citta and the Caitasikas is simultaneous.

A word must be said concerning the traditional order of the skandhas. In the sūtras they are invariably enumerated in the order given above. The philosophers might see fit, as did Buddhaghosa and Nāgārjuna, to depart from this order when dealing with them philosophically, but as regards mere enumeration they held fast to the traditional order. Nevertheless, in the sūtras themselves no reasons are ever given for this order, but in the Abhidharma Kośa we find an attempt made to defend the time-honoured enumeration (A.K. 1-17b).

"The order of the skandhas is given in accordance with their relative coarseness and impurity with reference to the plate simile and in accord with the enumeration of the dhātus. Rūpa being impenetrable, it is the coarsest of the skandhas. Among the non-material skandhas Vedana is the coarsest, just as everyone speaks of his hand, etc., being painful. Samjñā or ideation . . . is the next in coarseness, since the notions, man, woman, etc., are easy to understand. Samskāra is coarser than Vijñāna, as the forces of hate, etc., are easy to understand. Vijñāna is the finest of them all, and since it universally grasps the characteristics of all other objects it is difficult to understand. Thus the order of the skandhas is in accord with their relative coarseness.

"From the very beginning until now men and women have been mutually attracted by one another's rüpa. This arises from abandoning oneself to passionate feelings (Vedanā). Giving oneself over to pleasure is due to erroneous ideation (Samjñ̃ā). This erroneous ideation is dependent upon the 
Kleśas (Sampskāras). The Kleśas arise in dependence upon Vijñana, and on the other hand the first three defile Vijñāna once they have arisen. Thus the order of the skandhas is in accord with their mutual defilement.

"Again, rūpa is like a plate. Vedanā is like food or drink contained in the plate. Saṃjñā is like a sauce, Samskāra is like the cook, and Vijñana is like the eater. Thus the order of the skandhas is in accord with the simile of the plate, etc.

"Again, the order of the skandhas is in accord with the relative position of the dhātus (realms of existence); e.g. in the Kāma dhātu there are various subtle forms of desire where the rūpa characteristics are made manifest. In the Dhyānas of the Rūpa dhātu one finds sukha and prīti, etc., where Vedanā is particularly prominent. In the three first Arūpa heavens they grasp the idea of space, etc., so that here Samjjñā is the most prominent. In the highest heaven Cetana is the dominating factor, so that this realm is characterized by Saṃskāra. All these four are supports of Vijñāna."

\section{The Twelve Ayatanas and the Eighteen Dhätus}

The other categories of the subjective classification of existence consist of the twelve àyatanas and the eighteen dhätus. These had best be considered together. Both are categories which were formulated not from an analysis of the human personality nor from an objective analysis of the external world, but as the result of the investigation of the functions of consciousness, and the means whereby consciousness is produced. Here all the component parts of being are grouped together with reference to the part they play as consciousness producers, for Buddhism starts with the assumption that consciousness is not an eternal selfexistent thing but is the temporary product of certain pre-existent material factors.

Āyatana, says Mrs. Rhys Davids, means “ Place or sphere of meeting, or of origin or the ground of happening ". 1

1 B.Psy. sect. on Āyat. 
Vasubandhu (A.K. 1-15a) renders it the gate of production of the Citta and Caitasika dharmas. More freely we can explain the term as being the basis of consciousness, or the factors which bring about consciousness. In this category the various aspects of consciousness themselves are not included.

The Āyatanas are twelve in number, and are as follows :-

1. Object of sight

2. Object of hearing

3. Object of smell

4. Object of taste

Sense object.

5. Object of touch

6. Object of thought

7. Organ of sight

8. Organ of hearing

9. Organ of smell

10. Organ of taste

Sense organ.

11. Organ of touch

12. Organ of thought

Dhātu, like dharma, is defined as that which bears its own attributes, but Vasubandhu (op. cit.) says that the term means species or genus, or even element, just as one says that a mountain consists of certain elements : gold, silver, copper, etc. In like manner does the world consist of so many dhätus. Consequently, we may call the dhätus the factors of consciousness, or more correctly the elements of existence, regarded from the standpoint of consciousness and its causes, since the dhätu category contain all the twelve āyatanas, and in addition the six major divisions of consciousness itself, making eighteen in all. These are :-

1. Sight object

2. Sound object

3. Smell object

4. Taste object

Sense object.

5. Touch object

6. Mental object 
7. Sight organ

8. Sound organ

9. Smell organ

10. Taste organ

11. Touch organ

12. Mental organ

13. Consciousness dependent upon sight

14. Consciousness dependent upon sound

15. Consciousness dependent upon smell

16. Consciousness dependent upon taste

17. Consciousness dependent upon touch

18. Consciousness dependent upon mentation

A few words concerning each of these factors will not be out of place.

1. The Fifteen Sensuous Factors, consisting of the five sense objects, the five sense organs, and the five-fold sense perceiving aspects of consciousness. These are not so likely to be misunderstood, but to each term a somewhat peculiar interpretation was given.

\section{(a) The Five Sense Objects}

These consist of visible objects, audible objects, etc. Consider carefully the word object. The substantialist would say that there is but one substance, which is perceived in different ways by the five senses, is seen by the eye, is touched by the hand, etc. Not so for the Buddhist, particularly after the atomic theory had been accepted: ${ }^{1}$ Every material object consists of molecules (Samghāta paramāṇu, or Kalāpa). Each molecule contains at least one visual atom (drāvya paramānu), i.e. one atom which affects the eye and no other sense organ, one taste atom which affects the tongue and no other sense organ, etc. Consequently, the sense organs receive in reality impressions from different objects, even though these objects or atoms all form part of a single molecule, or atomic group. Concerning the nature of these atoms and

${ }^{1}$ Cf. A.K. 4-l $a$ ff., where all the following points are discussed; also f. 30. 
molecules, and the way in which they are produced and destroyed, we shall speak more at length hereafter. Suffice it for the moment to say that these atoms are not eternal, but are derived from the four elements. The four elements are themselves atomic, are cognizable by touch alone and not by any other sense organ, though their existence may be inferred by the reason acting upon the data given by the other senses.

The fact that the object of sight must be a different substance from the object of taste, etc., is really inherent in the word dhātu, element, or factor, for if the object of sight and the object of taste were really one and the same they would constitute one dhātu and not two.

\section{(b) The Sense Organs}

In the same way the sense organs, according to the Buddhists, are not what we usually mean by the term. The Cakșurindriya is not the eyeball, but certain atoms of a peculiar kind scattered over the ball of the eye and possessed of the faculty of vision. The nose sense-organ consists of specific kinds of atoms scattered inside the two nostrils and possessing the faculty of smell, and so on with the others. The organ of touch, for example, consists of a large number of atoms scattered throughout the body, and possessed of the faculty of (tactual) feeling.

These five kinds of atoms are quite distinct in kind from the five sense-object atoms, though they are equally derived from the four elements. ${ }^{1}$ Those parts of the body which do not form part of the sense organs consist of molecules or atom groups of the five sense atoms, with their attendant element atoms.

The sense organs in the ordinary sense of the word, i.e. the sense orifices, are sometimes called the auxiliary indriya or faculties. ${ }^{2}$ Incidentally, the double nature of the orifices of the eye, ear, and nose called for comment from the Buddhist

$$
1 \text { Ab. Hr., 1-2a. 2 A.K., A.K. 2, last part. }
$$


philosophers, and we find them stating that the number of the dhätus is not thereby increased because (A.K. 1-13b) " though twofold, yet as their species, their sense-object, and their resultant consciousness is the same, their nature is one".

When, further, they paused to consider why these particular orifices were two-fold, the older explanation was that these orifices were made in pairs for the sake of adornment, as with but a single orifice sentient beings would appear hideous. But the philosophic Vasubandhu objected to this explanation, and argued that their two-fold nature (A.K. 1-14a) was due to more practical reasons, viz., that we may have a clearer or more exact impression of the external object. When we look at an object with one eye closed, we are unable to see it clearly.

(c) Sense Perceiving Aspects of Consciousness

The five aspects of consciousness concerned only with the cognition of sense data arise from the interaction of sense object and sense organ, or more accurately the sense-object atoms and sense-organ atoms. The transient nature of consciousness, and incidentally of the sense objects and sense organs, is seen from the following citation from the Samyutta Nikāya: "Consciousness comes into being, monks, because of two things. Because of the sight organ and visual object there comes into being visual consciousness. The organ of sight is impermanent, fleeting, constantly changing. Visible objects are the same. Visual consciousness arising from such a conditioning relation which is impermanent, fleeting, constantly changing, is itself no less so, for how can it be that consciousness arising from such an impermanent relation can itself be permanent" (S.N. iv, 67).

Two further details call for mention. Later Buddhists, when dealing with sense perception, laid great emphasis on the distinction between individual perception (svabhāvalakșaṇa) and aggregate perception (samjñāna-lakșaṇa). The sixth aspect of consciousness, mano-vijñāna, was considered 
to have aggregate perception, or to be cognisant of objects, common to all the same organs. But the first five vijñānas were limited in their scope to their own field of action, they had only an individuate cognizance of the homogeneous object immediately in front of them, and did not encroach upon other fields.

This individuality of perception, however, only referred to each vijñāna cleaving to its own àyatana. Inside of its own sense group, every vijñāna and aggregate perception as may be seen from the following discussion in the Abhidharma Kośa $(1-8 a)$. Objects of touch were divided into eleven divisions. Some teachers thought that at any one time tactual consciousness could only perceive one derivative and four elemental groups, owing to the doctrine of svabhāva-lakșaṇa, but Vasubandhu says that tactual consciousness can perceive all eleven simultaneously, because, all being within one ayatana, they did not constitute a case of samjuñāna-lakșaṇa.

Again, Buddhism asserted that Vijñāna has three kinds of cognizance or Saṃkalpa. ${ }^{1}$ One, Svabhāva saṃkalpa, is immediate sense perception of the object presented to it; the second, Smrti samkalpa, is memory or the cognizance of present sense data associated with the memory of former similar and dissimilar sense impressions. The third, Samprayoga samkalpa, may be called reasoning or intellection based upon sense data. Of these three functions of consciousness, Mano-vijñāna possesses all three. The first five vijñāna are possessed of Svabhāva saṃkalpa alone.

2. The Five Non-sensuous Dhätus present some of the most interesting problems of Buddhist philosophy, though for the present we can but consider their bare outline.

\section{(a) The Sense Object}

The mind proper or mental cognition is considered a sense in the same way as the first five vijñanna. Consequently it,

1 I have not found this doctrine in Pāli tradition, but it is common to both Sarv. and Yog. schools, see A.K. 2. 
too, is possessed of the three-fold distinction of sense object, sense organ, and sense perceiving aspect of consciousness. The sense object in this case consists of those things which are the subject of mentation. Thus, in so far as we reason or think about Nirvānạa, Nirvāṇa becomes a sense object, or the object of Mano-vijñanna. The formulation of the group of factors constituting this dhātu was obviously subsequent to the Sūtra period, for we find some difference of detail among the various schools.

The Sthaviravādin ${ }^{1}$ enumeration is as follows :-

1. Nirvāna, the highest reality.

2. The subtle forms of Rūpa matter which cannot be perceived by the physical sense organs, or their associated vijñāna.

3. Citta, or mind itself.

4. Caitasikas, or mental properties.

5. Prajñapti, or concepts or notions.

The Sarvāstivādin ${ }^{2}$ in enumeration was :-

1. The Vedanā, Samjjñā, and Samskāra skandhas, with all their numerous subdivisions.

2. Avijñapti Rūpa, or unmanifested rūpa.

3. The three Asamskrta dharmas, or the transcendental and permanent factors of existence, making seven divisions in all.

The Yogācārin ${ }^{3}$ enumeration was :-

1. The Caitasika dharmas.

2. The Citta-viprayukta dharmas.

3. The six Asamskrita dharmas.

4. The subtle forms of matter. These four categories when subdivided make eighty-two dharmas in all.

At first sight there appears to be a great deal of divergence of opinion concerning mental object among the three schools

1 C.P., p. 3 and p. 120.

2 A.K. 1-10.

3 A.V.P. 1-1 $a$, see disc. 八宗綱要. 
which we are considering. But a good deal of the difference is more apparent than real, as will be seen when we come to deal with each of the above-mentioned groups. It will be better, however, to postpone all discussion of the matter until we come to examine them from the point of view of objective analysis.

\section{(b) Sense Organ}

In many of the later Sthaviravādin commentaries it is said that the sense organ of the Mano-vijñanna is the physical heart, which takes the place of the brain in most Oriental calculations. This, however, is not mentioned in the Pitakas themselves, and in their enumerations of the twelve ayatanas and the eighteen dbātus they agree with the other schools of Buddhism in making the manas (or mind)-an abstract entity-the organ of Mano-vijñāna. What is this curious thing called the mind or manas which is thus contrasted with mental cognition, or Mano-vijñāna? At present I am aware of no Pāli text dealing with the matter, but Vasubandhu tells us (A.K. 1-12a) that the "flux of the six vijñannas constitutes Manas", and, again, $(b)$ "the continuous passing away of the six vijñannas forms manas ... The continuous passing away of the group of six vijñānas, causing later vijñānas to arise in their place, is called Mano-dhātu, just as the child of this (man) is called the father of that (man), or as the fruit of this tree is called the seed of that tree." In other words, each of the six vijñanas has only a momentary existence. Nevertheless, there is a Karmic or causal affinity between the various groups of consciousness of one moment and the next. The group of this moment inherits the tendencies, etc., of the immediately preceding group, and as the chief function of Mano-vijñannas is memory and reason, both inseparately connected with the continuity of the mental process, it is said that the constantly dying away vijñanas of the past moment constitutes the base or organ for the activity of the Manovijñanna of the present moment. Just as the activity of the 
cakșur or indriya brings about the arising of Cakṣur-vijñāna or the visual consciousness, so does the transmitted energy of all the immediately preceding vijñanas bring about the arising of the Mano-vijñāna.

\section{(c) The Sense-perceiving Consciousness}

At the present moment little need be said about the nature of the Mano-vijñana. We have already said that this aspect of consciousness possesses aggregate as well as individual perception, as opposed to the other five types of consciousness, and, moreover, while the latter has only svabhāva samkalpa, the former has samprayoga samkalpa, and smrti samkalpa as well. Nor must it be forgotten that the Yogācārins added two other types of consciousness, which shared some of the attributes and functions of the old Manovijūāna.

The Buddhists laid great stress upon their division of the universe into the eighteen dhātus or elements, and used these categories to explain many of the functions of life, and just as the Vaiśeșikas, after enumerating their list of dravya or substances, proceeded to expound the list of gunas or qualities or attributes possessed by each of these substances, so did the Buddhists give a good deal of attention to the characteristics of each of the eighteen dhātus, even though the non-substantialist position of Buddhism made it impossible for them to carry out the theory of inherent attributes possessed by self-existent substances. Consequently, in place of a list of fundamental inherent gunas, the Buddhists, after enumerating their list of dhātus, merely attempted to place them in different logical groups; e.g. those which are visible, and those which are invisible; those which are defiled (sāsrava), and those which are not defiled (anāsrava); those which are objective and those which are subjective, etc. For the most part, however, these classifications were of little philosophic import, so that we may rest content with referring the curious to the original authorities. 


\section{(B) The Objective Classification}

We now come to the consideration of the component parts of the universe classified and analysed from the objective standpoint. Here no longer does the human personality or the process of consciousness serve as the starting-point. Rather are the phenomena of life, both mental and physical, considered universally.

Here, also, do the component parts of the universe receive a new designation. It is curious to note how many terms there are which we are forced to render " elements" or " factors of existence". The difference in terminology has almost exclusive reference to the standpoint from which the analysis of the universe was made. A word must now be said concerning their relationship.

The skandhas or component parts of the human personality are for the most part aggregates or compounds and not themselves ultimate or simple factors of existence. Vedanā and Sampjñā, to be sure, are treated as ultimates. The Sarvāstivādins state, moreover, that all the various classes of vijñana constitute but one ultimate factor, but the other schools consider even the vijñana skandha as composite. Rūpa and Saṃskāra are certainly names for groups of elements and not true ultimate factors themselves.

The dhātus come nearer to a scientific conception of ultimate factors, since all but one (dharma dhātu) are discrete, simple, ultimate elements. Dharma dhātu, however, is a generic term, and includes a great many discrete factors.

With the enumeration of the dharmas, however, an attempt (even though not altogether successful) was made to enumerate those factors which are themselves the underlying units of the other groups, and to them, therefore, may we properly assign the term element or ultimate factor. The word factor rather than element has been chosen, inasmuch as the latter term has been usurped by the four Mahābhūtas. The dharmas include not only these elements, but apply also to the mental and other spheres. 


\section{MANUAL OF BUDDHIST PHILOSOPHY}

The dharma classification came to have more and more importance assigned to it in the subsequent developments of Buddhist philosophy, and finally usurped most of the attention previously given to the skandhas and dhātus. It is, therefore, imperative that careful investigation be made both of the meaning of the term and the objects denoted by it.

\section{The Meaning of Dharma.}

Dharma has been used in a great variety of senses. It has been well called the blank cheque of Indian thought. In the present instance, however, it has no relation to the more usual significance of truth, law, religion, duty, etc. Along with dhātu, and for similar reasons, it has been defined as " that which bears its own attributes", meaning thereby ultimate entities possessed of their own characteristics, as opposed to groups of phenomena whose characteristics are derived from ultimate substances which underlie them. Being thus contrasted with phenomenal groups and constituting the factors of which such groups are composed, Mrs. Rhys Davids' rendering of the term by "phenomena" (in her trans. of the Dham. Sang.) is by no means happy, while her "mental states" is still less so, since many of the dharmas are not mental (as she herself admits).

On the other hand, "ultimate factor" and "element" are equally liable to be misunderstood, for the doctrine of the dharmas never conflicts with the anti-substantialist position of Buddhism. Only the Asaṃskṛta dharmas (Nirvāṇa, etc.), which are purely transcendental, are uncaused and underived. The other dharmas are not like the eternal substances of the Jainas and Vaiśesikas, which are uncaused, eternal, and possessed of certain inherent attributes which remain unchanged even though all of their manifested attributes undergo transformation. Every single one of the Samskrta dharmas or factors of phenomenal life are impermanent, caused, conditioned. Thus, for example, the atoms of the five sense organs and the five sense objects (each sense organ 
and sense object is counted a dharma) are derived from the four elements, are in continuous dependence upon them, and are frequently destroyed and recreated. Moreover, the Buddhists do not like to admit that the dharmas are invisible substances (things in themselves) possessed of a number of inherent attributes which alone appear to us. That thing which we see is the sense object, and not merely some one aspect inherently existing in a self-constituted substance. It was probably for this reason that the name dharma (bearer of its own attribute) was given to it. As has been very wisely pointed out by Mrs. Rhys Davids, "This, to us, very obscure characterization may very likely mean that dharma, as phenomenon, is without substratum, and is not a quality cohering in a substance." 1

Dharmas themselves are phenomena in the sense that they are not eternal substances, but they are not phenomena in the usual Western sense of modes of other underlying substances. The sense organs are derived from and dependent upon the four Mahābhūtas, but they are separate entities possessing their own characteristics, and not aspects, attributes, phases or modes of the Mahäbhūtas.

They are ultimate in the sense that they are simple and not composed of finer heterogeneous units. Thus, for example, though the sense organs may be composed of atoms, every cakșur indriya paramānu is uniform and homogeneous, so that all such paramānus together constitute but one dharma or factor of existence. They are thus ultimate when contrasted with the physical body, let us say, which consists of sense organ atoms, and sense object atoms, as well as the four Mahābhūtas themselves.

The propriety of the term "factor" as a rendering of dharma is also to be seen from two further considerations. One is the so-called permanence of the dharmas, and the other is the list of things which are called dharmas.

1 Dh. San. Intro., p. xxxiv (trans.). 
First, as regards their permanence (一切法常有). Supposing that no other form of organic existence were possible other than that which we see around us to-day, we could say that the eye is a permanent factor in human life, even though every single eye is necessarily impermanent, and subject to decay. In the same way the various dharmas are permanent factors in life, even though every one of them is constantly being destroyed and recreated.

Second, as regards the curious list of dharmas which both the Sthaviravādins and Sarvāstivādins enumerate. Both contain certain things which can be called neither mental nor material, though many of these are inconsistently classed by the Sthaviravādins under rūpa skandha, while the Sarvāstivādins enumerate them, more logically, as a separate group unconnected with either matter or mind. Among these are homogeneity, decay, vitality, birth. The Sarvāstivādins say that these are not merely modes of other substances, but are themselves separate dharmas or ultimate factors of life.

From the foregoing we may see that the conception of "dharma" is one of the most original contributions of Buddhism to the history of human thought, much in the same way as Plato's "Ideas" and Aristotle's "Forms", or the doctrine of substance. Many Buddhist ideas are derived from, or at least shared with other systems of thought, but the doctrine of dharma has no exact parallel with any other conception, so that it is most curious that no one has as yet dealt with the curious philosophic position which the doctrine involves.

\section{Classification of the Dharmas.}

Having thus examined the meaning of the word dharma, let us now turn to the enumeration of the dharmas themselves. First as regards their grouping.

In the Abhidhammattha-sangaha, ${ }^{1}$ representing the Sthaviravādin tradition, we find the following arrangement :-

$$
1 \text { C.P., p. } 81 .
$$


1. Citta, or mind, consciousness.

2. Caitasikas, or mental, properties.

3. Rūpa, or matter.

4. Nirvāna, or the highest reality, sometimes defined as Asamskṛta.

The Sarvāstivādin classification (A.K. $4-1 a$ ) is ${ }^{1}$ :-

1. Rüpa, or matter.

2. Citta, or mind.

3. Caitasikas, or mental properties.

4. Citta-viprayukta, or miscellaneous factors.

5. Asamskrta, or unconditioned factors, one of which is Nirvāna.

The Yogācārin ${ }^{2}$ classification is :-

1. Citta, or mind.

2. Caitasikas, or mental properties.

3. Rūpa, or matter.

4. Citta-viprayukta, or miscellaneous factors.

5. Asamskrita, or unconditioned factors.

All three schools agree in calling those dharmas which are not definitely Asamskrita, Samskṛta, so that in reality there are but two great categories: (1) The Asamskrta or Eternal, unconditioned elements of existence which do not enter into combination; and (2) Samskrita, conditioned and impermanent elements which enter into combinations to form the phenomenal world around us. This second group, as we have seen, the Sthaviravādins divide into but three categories, while both the Sarvāstivādins and the Yogācārins postulate four. This fourth category, Citta-viprayukta, means, literally, not connected with mind, but it is also defined as being equally disassociated with matter or rūpa. This category consists of certain dharmas which are somewhat incongruously placed under rūpa by the Southern Buddhists, 
together with certain dharmas which are not found in the Southern list at all.

Although there is some disagreement as to the exact number of dharmas included under each category, all the schools agree that rūpa dharmas consist of the component units of the Rūpa skandha ; Citta dharmas of the component parts of the Vijñana skandha; while the Caitasikas consist of the Vedanā and Samjuña skandhas, together with the component parts of the Sampsāra skandha. According to the Sarvāstivādins and Yogācārins, the Citta-viprayukta dharmas are also included in the Samskāra skandha.

There is also comparative unity of opinion concerning the relationship between the dharmas on the one hand and the dhātus and ayatanas on the other. The five sensuous sense organs and sense objects belong to the Rūpa dharmas. The five sensuous forms of consciousness belong to the Citta dharmas. To this category also belongs the sixth or Manovijñāna, and Mano-dhātu, while the remaining dhātu or ayatana, the object of mentation, includes all the other dharmas.

The accompanying chart will serve to make clear the relationship supposed by all the schools to exist between the skandhas, the āyatanas, the dhātus, and the dharmas.

In the earlier stages of all three schools there seems to be a good deal of deviation and inconsistency in the enumeration of the dharmas. In this period no exact numerical definition seems to have been given, but in the later stages of each school an attempt was made to fix artificially the number of each group as well as the total number of dharmas. ${ }^{1}$

Thus in the Sthaviravādin school, Rūpa consists of twentyseven or twenty-eight, Citta of eighty-nine, Caitasikas of fifty-two dharmas, while Nirvāna consists of an additional dharma, but no especial mention seems to be made of the total number of dharmas taken as a whole.

1 For author, see list above. 
Among the Sarvāstivādins subsequent to the Abhidharma Kośa, the total number of dharmas was fixed at seventy-five, three being allotted to the Asamskrrta dharmas, eleven to Rūpa, one to Citta, forty-six to Caitasika, and fourteen to Citta-viprayukta.

Among the Yogācārins subsequent to the Vijñāna-mātra Siddhi, the total number of dharmas was fixed at a hundred, six being allotted to Asamskrita, eleven to Rūpa, eight to Citta, fifty-one to Caitasika, and twenty-four to Cittaviprayukta.

This gives us the following comparative tables:-

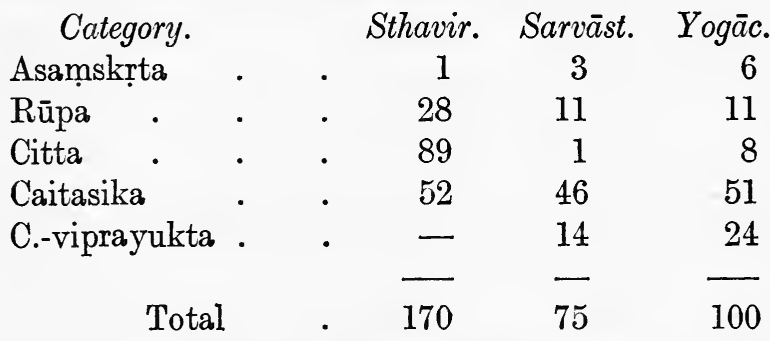

\section{The Asamskrta Dharmas}

All forms of Buddhism agree in dividing the dharmas into those which are Asamskrrta and those which are Samskṛta. Samskrta comes from the root Sam = with; and krta, done or performed. Accordingly, the word is literally the same as the Latin confectus. The Pali commentaries take samskrta to mean conditioned, implying that the Samskrta dharmas are caused, conditioned, mundane, temporal, impermanent, non-eternal, active, and associated with the Āsravas or taints. As opposed to these are the Asamskrita dharmas, which are not subject to cause, condition, or dependence, and are therefore transcendental, out of time, unchanging, eternal, inactive, and free from the Āsravas. Mrs. Rhys Davids, in an appendix to her translation of the Dharma Sangani, has collected a list of adjectives applied to the Asamskrita dharmas. These may be studied with advantage. 


\section{MANUAL OF BUDDHIST PHILOSOPHY}

1. The Sthaviravädins, ${ }^{1}$ however, know of but one Asamskṛta dharma, Nirvāṇa. Nirvāṇa is to be gained by the annihilation of the roots which lead to rebirth, and may, therefore, be called the cessation of phenomenal life, though a person who attains to Nirvāna continues in bodily existence until his span of life is exhausted, after which the phenomenal dharmas which compose his personality disintegrate, having no further creative force to keep them together. Nirvāna, then, is of two kinds: (1) Nirvāna with a subsidium, or Nirvāna associated with a still existing personality ; and (2) Nirvāṇa without a subsidium, or the state of Nirvāna after the phenomenal personality has disintegrated. The fact that Nirvāna is called a dharma shows that it was considered a positive concept and not a mere negation of life.

2. The Sarvāstivādins enumerate three Asamskruta dharmas. These are: (1) Ākāśa, (2) Pratisamkhya Nirodha, and (3) Apratisamkhya Nirodha.

(a) Ākāśa corresponds to what in the West is called either space or ether. Vasubandhu says (A.K. 1-3b) it has for its characteristic non-impeding, and since it offers no obstacle, matter (rūpa) freely functions therein. The fact that Ākāsa is always considered a substance and an eternal and unchanging unity shows that Ākāśa is not merely empty space, or lack of matter, but a positive entity having many attributes common to the old idea of ether.

An important point to notice in this connexion is that the

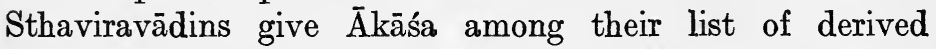
material dharmas produced by the four Mahābhütas, while with the Sarvāstivādins it is elevated to the rank of an Asamskrita dharma. In point of fact, however, the Sarvāstivādins seem to distinguish between two kinds of $\bar{A} k a \bar{s}$ á, the first the eternal and omnipresent ether, the other to empty space, with which is frequently associated the sky. The first is translated by the Chinese as 虚空 (hsü k'ung), 
and the second by 空 (k'ung) alone. The second concept agrees more or less with the Sthaviravādin conception of Ākāśa. Thus the Mahāvibhāṣa (75-9b): “Hsü-k'ung is not rūpa, while k'ung is rūpa (i.e. lack of rūpa, or interstices between rūpa). Hsü-k'ung is invisible, k'ung is visible. Hsü-k'ung is Anāśrava, k'ung is sāsrava. Hsü-k'ung is asamskrta, while k'ung is samskrta." In each case the definition of k'ung corresponds to the Sthaviravādin Ākāśa.

In another passage Vasubandhu (A.K. 1-21b) brings out the strong difference between the Asamskrxta Ākāsa and the Ākāśa, which is merely empty space. " $\mathrm{K}$ 'ung is an interstice (or hole) ... The apertures in a gate (as regards inanimate objects) or in the mouth or nose (as regards animate objects) are called k'ung."

From this it would seem clear that the Sarvāstivādins regarded the Asamnskṛta Ākāśa as ether, and the Samskrịta Ākāśa as space.

(b) Pratisamkhya Nirodha is conscious cessation. Vasubandhu (A.K. 1-3b) says : "It has for its nature freedom from bondage ... Pratisamkhya means conscious deliberation, and is a type of intelligence since it deliberates upon each of the four Noble Truths. The attainment of cessation (Nirodha, i.e. the cessation of the taints and passions) by means of the power of deliberation is therefore called Pratisamkhya Nirodha, just as a cart pulled by bullocks is called a bullockcart by the elimination of the middle term." Vasubandhu then goes on to discuss whether this Pratisamkhya Nirodha is uniform and homogeneous, i.e. whether the attainment of freedom from one bond implies simultaneous emancipation from all others, and he answers (op. cit.): "By no means, for it differs according to the basis of the bondage; that is to say, the emancipation from bondage is in accord with the extent of basis of the bondage. If this were not so, when one annihilates one kleśa ... all other kleśas would thereby be destroyed, and, consequently, training in order to master the others would be unnecessary" (which is false). 
Nevertheless, although emancipation from the kleśas must be accomplished individually, yet this process leads to complete freedom from all bonds in the end, and so Nirvāna, or complete freedom from all bonds by means of conscious effort, comes within this category, and thus Pratisamkhya Nirodha is identified with the only Asamskrta dharma known to the Sthaviravādins.

(c) Apratisamkhya Nirodha, in contrast with the preceding, is "unconscious cessation", and is explained as the nonarising of consciousness, not as the result of conscious effort, but by lack of the necessary sufficing conditions. Vasubandhu (A.K. 1-14a) says: "Just as when the mind is intent upon one object, all other objects of sight, sound, smell, taste, and touch are lost, because the group of the five vijnannas remains in the not-yet-arisen (or future) state and consequently never arise at a later moment since they are unable to perceive past-sense objects. In like manner, because of the incompleteness of sufficing causes, Apratisamkhya Nirodha is brought about."

Each of the three Asamskrta dharmas, according to the Sarvāstivādins, is separate and discrete. Consequently, they are pluralists, inasmuch as they accept more than one eternal unconditioned element.

3. The Yogācārins.-In contrast to the Sarvāstivādins, the adherents of the Yogācārin school enumerate six Asaṃskṛta dharmas. ${ }^{1}$ These are: (1) Ākāśa, Pratisaṃkya Nirodha, (3) Apratisamkhya Nirodha, (4) Acala, (5) Samjjñā-Vedanā Nirodha, (6) Tathatā. The first three are the same as the Asamskrta dharmas of the Sarvāstivādins, and, therefore, need not be discussed. The additional three are :-

(a) Acala is, literally, immovability. This is a mental state identified with Upekșā, or indifference, or the trans-

1 Sat. dh. dv., p. 2, V.M.S. f. 1, G.V.P., and A. Sam. San. enumerate eight Asamsk. by dividing Tathatā into three classes. 
cending of both pleasure and pain, and is associated with the third and fourth Dhyānas of the Rūpa dhātu; it is also associated with the mental states of the first three divisions of the Arūpa dhātu.

(b) Samjuñā-Vedanā Nirodha. This is the state of trance in which both saṃjñā (ideation) and vedanā (feeling) cease (nirodha). At this point the aspirant enters into the Nirodha samāpatti. This stage is associated with the mental condition prevailing in the fourth Arūpa heaven.

(c) Tathatā, literally suchness, or the true nature, or the Absolute, which, according to the Yogācārins, is the ultimate reality underlying all phenomena. "This is the ultimate essence of everything, and it is termed Bhūtatathatā or permanent reality, because it is both real and eternal, though its true nature cannot be grasped by words or ordinary conceptions."

The addition of this dharma made a complete revolution in Buddhist philosophy, particularly as compared to the ontology of the Sthaviravādin and Sarvāstivādin schools, for, whereas according to these latter systems each of the dharmas is eternally distinct, according to the Yogācārins all dharmas are but modes of the one fundamental "essence of mind ".

Consequent upon this idea, the Yogācārins go on to say that the enumeration of the preceding five Asamskrita dharmas belongs to the realm of relative truth, since in reality there is but one Asamskrta, namely the last or Tathatā, while the others are but different ways of conceiving it.

The Absolute, as the ever-present, non-impeding reality, is called Ākāsa; as free from the limitations of the phenomenal world (of which, however, it is the underlying reality) it is called "Pratisamkhya Nirodha", especiaily when this state is regarded as the result of conscious effort. The term "Apratisamkhya Nirodha" is also used to show that the Absolute manifests itself when the conditions which obscure it are absent, that its existence continues even when other 


\section{MANUAL OF BUDDHIST PHILOSOPHY}

conditions bringing about phenomenal existence do not arise. The fourth and fifth Asamskrta dharmas are but inferior stages leading to noumenal existence.

\section{Rūpa, or Matter ${ }^{1}$}

Having finished our survey of the Asamskrta dharmas we now turn to the Samskrta dharmas, or the ultimate factors, which enter into combination in the phenomenal world; and of which they are the proximate cause. Consequently, they are defined (A.K. 1-4b) as " mundane, temporal (i.e. belonging to the world of time), possessed of causes and conditions, phenomenal, capable of being described by words, tainted (sāsrava), and associated with the two truths Duhkha and Samudaya". Since these are the ultimate parts of phenomenal life, and such life consists of matter and mind (including the phases of the mind), such dharmas are classified into Rūpa, Citta, and Caitasika dharmas, to which other schools would add Citta-viprayukta dharmas.

Let us first consider the Rūpa dharmas, or the material factors of existence. All schools of Buddhism agree that every material dharma falls into one or other of two categories : (1) The ultimate or underived, and (2) the derived. They are generally agreed that the ultimate dharmas are four in number and consist of the four Mahābhūtas, or four material elements, which are earth, water, fire, and air, though each of these terms has a very special significance for the Buddhists.

Regarding the enumeration of the derived material dharmas, there is not quite such uniformity, though all lists include the five sense objects and the five sense organs, however many other dharmas may be given.

1 For Str. p. 3 of Dh. San. (Book 2 of Rt. Trans.), C.P. part vi, p. 154 ff. For Sarv. Wu-shih-p'i-p'o sha lun, first half of first fasc., A.K., first half of first fasc. ; for Pr. and M.V. fifth grantha. For Yog. A.V.P. 1-36 and 4a, A.S.S., p. $2 a$. 


\section{(a) The Ultimate Material Elements}

These, the four Mahābhūtas, require, as we have said, especial attention, as they are easily misunderstood. The use of the terms in the Hinnayana sūtras is somewhat vague, so that we are left uncertain as to what interpretation was given to them in primitive times, but all the later schools agree that the elements are themselves only perceptible through touch. What we see, hear, smell, or taste, are only sense objects derived from the elements. Even as regards the faculty of touch, certain of the things sensed are only derivative sense objects, though, in addition, the touch sense organ can perceive the elements themselves.

The Abhidharma Kośa (1-9a, where a detailed discussion will be found) gives us the following chart of the attributes and functions of each of the four elements :-

Name.

1. Earth

2. Water

3. Fire

4. Air
Attribute.

Solidity

Moisture

Heat

Motion
Function.

Supporting

Cohesion

Ripening

Expanding

Every molecule of every material object contains at least one atom of each of these four elements. Thus a molecule of what we call water contains atoms of earth, water, fire, and air, in addition to the atoms of the sense objects, but it so happens that for the time being the water element has a predominant influence, so that we call the molecule in question water. The Abhidharma Kośa (4-1b) has the following statement concerning the matter. "Query: If the four Mahābhūtas always arise together, in all molecules, whether hard or moist, hot or mobile, how is it that we can sense one and not the others? Answer: Because for the time being the nature of one happens to be predominant, so that our senses notice one and not the others." The Mahāvibhāṣa is even more emphatic on this point, and in one passage 


\section{MANUAL OF BUDDHIST PHILOSOPHY}

(31-15b) gives long arguments to support the Buddhist position.

In this connexion one doctrine peculiar to the Sthaviravädin school must be noticed. They believe that only three of the Mahābhūtas are tangible, i.e. that the water element cannot be felt, and, as no element is perceptible to the other senses, it follows that the very existence of this element can only be known by a process of inference. Thus we find S. Z. Aung (C.P. 155n) saying: "Particles of matter are held together by Apo (cohesion) (water) which cannot be felt by the sense of touch-e.g. when one puts his hand into cold water, the softness of the water is not apo but pathavi (earth), the cold felt is not apo but tejo (fire), the pressure felt is not apo but vayo (air) . . . From this one can easily see that the Buddhists are not dealing with Thales' water, Anaximenes' air, Herakleitus' fire, or the Peripatetics' matter of Greek philosophy."

For this reason we should prefer to call the mahābhūtas forces rather than material elements, except for the fact that they are considered atomic and therefore are obviously material.

What is the connexion between the four ultimates and the various derivative forms of matter? Buddhaghosa, representing the Sthaviravādins, merely says that a derivative form of matter is aided by the four elements supporting (earth), binding (water), maturing (fire), and moving (air) it, like an infant prince being fed, bathed, dressed, and fanned. (Att. Sal. quoted Dham. Sañg. R. D. trans., p. 174.)

The Sarvāstivādins and the Yogäcärins deal more explicitly with the causal relation between them, giving a five-fold relationship, one for each of the mahābhūtas taken separately, and one for them altogether. The Mahāvibhāṣa (127-6b) gives us the following chart :-

1. Producing, as a mother gives birth to a child . . . . . . . all four.

2. Reliance, as a disciple relies upon his teacher fire. 
3. Establishing, as the earth holds or sustains things . . . . . . . earth.

4. Sustaining, as food supports food . . water.

5. Nourishing, as water fertilizes the roots of trees . . . . . . . air.

The Abh. Sam. San. (1-2a), representing the Yogācārin school, defines each of these causal relations in the following way :-

1. Producing.-This is the originating cause, because the derivative dharmas cannot arise apart from the activity of the Mahābhūtas.

2. Reliance.-This is the transforming cause, because, apart from the Mahābhuitas, the derivatives have no intrinsic qualities of their own.

3. Establishing.-This is the co-ordinate transforming cause, because whenever the Mahābhūtas undergo modification the derivatives undergo a like transformation.

4. Sustaining.-This is the cause of continued existence, because, depending upon the mahābhūtas, the derivatives do not cease, but have a continuous development.

5. Nourishing.-This is the cause of growth, because increase (or stimulus) takes place owing to the nourishing force of the Mahābhūtas.

\section{(b) The Derivative Dharmas}

The Sthaviravādins give twenty-seven or twenty-eight rūpa dharmas in all, of which twenty-three or twenty-four are derived from the four Mahābhūtas, while the Sarvāstivādins and Yogācārins have only eleven. It is probable, however, that the twenty-seven represent an earlier tradition, owing to the greater crudity of the method of enumeration. It seems likely that the more philosophic thinkers of the Sarvāstivādin and Yogācārin schools eliminated those dharmas which were inconsistent with a more logical, systematic, and scientific view of the universe. 


\section{MANUAL OF BUDDHIST PHILOSOPHY}

The following is a comparative list of the derivative material dharmas, as taught in the three schools :-

(1) Sthaviravādin. (2) Sarvāstivādin.

1. Sight organ.

2. Sound "

3. Smell "

4. Taste ",

5. Touch ",

6. Sight object.

7. Sound ",

8. Smell ,

9. Taste ",

10. Touch ",

11. Female Sex.

12. Male Sex.

13. Food.

14. Organ of Life.

15. Space (ākāśa).

16. Gesture.

17. Speech.

18. Buoyancy.

19. Elasticity.

20. Power of Adaptation.

21. Power of Aggregation (birth).

22. Duration.

23. Decay.

24. Death.

The curious crudity and illogicality of the Sthaviravädin school is at once obvious. Here are placed, side by side, material objects and the modes or activities of these organs, such as buoyancy or elasticity, birth, death, etc.

The Sarvāstivādins have taken some of the categories out of this list and placed them, more appropriately, among the Citta-viprayukta dharmas. Ākāśa, in the sense of mere empty space, the apertures of the body, etc., being but the 
absence of a thing, is not considered a separate dharma, although, as we have seen, Ākāśa, in the higher sense, is placed among the Asamskrta dharmas. The remaining dharmas of the Sthaviravādin list are ignored, for though masculinity and femininity were classed among the twentytwo indriyas yet, since they were not considered ultimate elements, they were omitted from the lists of dharmas.

It may, at first sight, seem strange to us that even the logical Sarvāstivādin and Yogācārin philosophers should have been content to keep the sense organs and sense objects as ultimate factors of existence, but the reasons for their doing so become obvious when the Buddhist theory of matter is taken into consideration. As we have already remarked in dealing with the dhātus, sight objects, smell objects, etc., are for the Buddhists really existing objects, separate from, though produced by the four mahābhūtas. Thus, what we consider a single material object, such as a lump of earth, is really something very complex. It contains not only minute particles of all the four elements which are invisible, but also minute visible particles, another set of particles which can be tasted, others which can be smelt, etc., and since, according to the premises, the whole universe of inanimate matter consists of compounds of these ultimate sense particles in addition to the four mahābhūtas, it would be inconsistent if they were not counted as separate dharmas.

It is the same way with the sense organs. The particles of the cakșur-indriya are quite different from the four mahābhūtas, and equally distinct from the five kinds of sense object atoms. Hence they are ultimate factors of existence.

Let us postpone for a moment examination of the eleventh categories of the Sarvāstivādins and Yogācārins and deal somewhat more in detail with each of the sense organs and sense objects.

\section{(i) The Sense Organs}

We have already learned to distinguish between what the world knows as sense organs and what the Buddhists consider 
to be the true sense organs. The physical eye is not the true sense organ, though it contains minute percipient particles which constitute the organ of vision. Thus the physical eye is complex. Its molecules contain atoms of the four mahābhūtas, and atoms of four out of the five sense objects (sound is generally, excluded). It also contains the body organ (kãya indriya) atoms, and finally the atoms of the caksur indriya itself. This idea, common to all forms of Buddhism, is expressed by Buddhaghosa in the following words :-

"First the aggregate organism (physical eye) . . . There are fourteen constituents: the four elements, the six attributes dependent upon them . . . vitality, nature, body sensibility (kãya indriya particles), and the visual sentient organ (the true sight sense organ) ... When the world seeing an obviously extended white object fancies it sees the eye, it only perceives the basis of the eye ... But that sentient organ which is there bound inherent, derived from the four great principles (mahābhütas)-this is the visual sense." (Att. Sal. quoted R.D. trans. Dh. San., 173.)

And so it is with the other sense organs, the matter of the five indriyas being quite different from the other kinds of matter. Sometimes the sense organs proper are called the principal indriya, while the sense orifices (e.g. the physical eye) are called the auxiliary indriya.

All accounts agree that the particles constituting the five indriyas are incredibly minute. Concerning their shape and their position we find the following statement :-

1. The Eye Indriya.-Regarding this the commentators quote the following verse :-

"The visual sense by which he beholds forms,

Is small and delicate, comparable to the louse's head."

(op. cit.)

Vasubandhu adds that the atoms of the cakșur-indriya are diffused over the surface of the eye. "Just as the particles 
of flour poured over the surface of the water would scatter on the surface of the water, so do the atoms composing the caksurindriya spread over the pupil of the eye" (cf. A.K. 2, 19).

2. The Sound Organ.-Buddhaghosa says that the units of the sound organ are situated within the cavity of the physical ear, and are well furnished with fine reddish hairs. They are in shape like a little finger-stall (? anguli-thanaka), or a finger covered with rings (op. cit. 178). Vasubandhu, on the other hand, states that they are screwed up just as the bark of a cherry-tree rolls up as soon as it is detached from the trunk (A.K. 2-19a).

3. The Smell Organ.--Buddhaghosa says that these particles are inside the nostrils, and in appearance are like a goat's honfs. Vasubandhu (op. cit. 19b) adds that they are like claws whose points face downwards.

4. The Taste Organ.-Buddhaghosa says that these particles are above the middle of the tongue, and in shape are like the upper part of the leaf of a lotus. Vasubandhu says they are in shape like a half-moon. It is interesting to note that the tongue and not the palate was considered the basis of the organ of taste.

5. The Touch Organ.-Regarding these particles, the commentators merely say that they are scattered all over the body. Vasubandhu states that the number of kãya indriya atoms is equal to those of the body proper, or more correctly that every molecule of the body contains at least one touch organ atom. He further tells us that the shape of these minute particles is not the same for men and women.

In this connexion one or two additional points call for consideration.

1. The later Buddhists distinguish between the eye and ear on one hand, and the nose, tongue, and body on the other. The latter can sense only that which is in immediate contact with them, while the former can sense that which is at a distance. The distinction does not seem to be met with in the original Sthaviravādin Abhidharma works, and among the 
Southern Buddhists the distinction is found for the first time in Buddhaghosa. S. Z. Aung is mistaken, however, when he tells us (C.P. 160) that the distinction began with Buddhaghosa, as it is insisted upon by the Sarvāstivādins both in the Mahāvibhāṣa and the Abhidharma Kośa (M.V. 13-7b and A.K. 2-7). Vasubandhu tells us, moreover, that the scope of the eye is even greater than that of the ear. It is to be regretted that the Buddhists did not tell us more concerning the nature of the medium between the sense organ and the sense object.

2. The Sarvāstivādins draw a distinction between the eye and ear on the one hand and the nose, tongue, and body, on the other, from another point of view. The former are able to sense any number of paramānus at the same time, as when we see either a mountain or a flea (A.K. 2-19a). The latter class of sense organs, however, can at any one moment sense only the same number of objective atoms as their own. If a certain sense object contains a greater number of atoms than the sense organ atoms with which they come into contact, the sense organs only sense at one moment the equivalent number of sense object atoms, and then sense the remaining fraction a moment later, the interval between the two periods being so small and the process of double sensation so rapid that we usually consider the whole affair simultaneous.

\section{(ii) The Sense Objects}

We have already seen how the Buddhists, in their rejection of the doctrine of substance, were forced to deny that what we experience are various qualities inherent in an external and unified object, but rather that when e.g. we perceive "red", there is really a separate atom of redness impingeing on the cakșur-indriya, and that this atom is a co-existing but independent atom in a molecule of objective matter. This doctrine was carried to its logical extreme no matter how strange the conclusions may seem to us. Thus, they 
claimed that there were atoms of shape as well as colour (though this was denied by the Sautrāntikas, A.K. 13-6), and that when we experience with the eye the sensation round, it is because there is an atom of roundness in the impingeing molecule. This can be seen from the discussion carried on in the first Chuan of the Abhidharma Kośa: "Some teachers say that some objects are possessed of both shape and colour... How can this be? (Attempted answer): Because we can see therein both (shape and colour). (Objection) : This sensation refers to our cognition, and not to the external object." (A.K. 1-7a.)

Consequently, when we see something that is both long and white, in reality we are sensing two separate atoms, and their unity is purely subjective. Most of our complex notions are thus reduced to a subjective compounding of a few simple external factors.

Needless to say, this philosophy, once accepted, led to a careful examination of just what things are ultimately objective and distinct. The final enumerations were only reached after considerable thought and controversy ranging over a long period of time, beginning with the crude and hesitating categories found in the Dhamma Sangani (which consequently had more or less to be followed by all the later Sthaviravādins) down to the logical lists of the later Sarvāstivādins. The Sarvāstivādins had, in fact, a much more definite list of categories than the Yogācāins, for, inasmuch as the latter thought that all matter is the product of the mind, the problem of the ultimate units of the objective universe was not for them an urgent one.

In the present instance, therefore, we may rest content with quoting Vasubandhu's ${ }^{1}$ enumeration of the divisions of each sense object which represent the Sarvāstivādin opinion on the subject, referring the curious to the other original authorities ${ }^{2}$ :-

1 A.K., f. 1, first half. Also M. Vyu., p. 195.

2 For Str. Shan-Sang. tr., p. 183 ff. For Yog. Abh. Sam. San., 1-2b ff. 


\section{MANUAL OF BUDDHIST PHILOSOPHY}

1. Types of Sight Objects.-(a) There are eight kinds of Saṃsthāna rūpa, or shape objects :-

1. Dirgha, or long.

2. Hrasva, or short.

3. Vrttta, or square.

4. Pārimaṇdala, or round.

5. Unnata, or high.

6. Avanata, or low.

7. Śăța, or even.

8. Visāṭa, or uneven.

(b) There are twelve kinds of varna rūpa, or colour objects, of which four are primitive and eight derivative :-

1. Nìla, or blue.

2. Pìta, or yellow.

3. Lohita, or red.

4. Avadāta, or white.

5. Abhra, or cloud colour.

6. Dhūma, or smoke colour.

7. Rajas, or dust colour.

8. Mahikā, or must colour.

9. Chāyā, or shadow (where objects can be seen).

10. Ātapa, or (dazzling) brightness (like sun).

11. Āloka, or light colour (like moon stars).

12. Andhakāra, or darkness (objects invisible).

2. Types of Sound Objects.-These are of eight varieties, obtained by dividing sound in two different ways: (1) according to the nature of the sound and the object which emits the sound; (2) according to the nature of the sound as judged by its effect upon the auditors.

The first division is that between (1) Upātta-mahābhūtahetuka, or sound produced by objects which have the power of perception, i.e. sentient agents; and (2) Anupāttamahābhūta-hetuka, or sound produced by objects not having the power of perception, i.e. non-sentient agents. These classes are divided into $(a)$ articulate sound, and $(b)$ inarticulate 
sound. Each of these four classes is again divided into pleasant and unpleasant, making the following eight in all :-

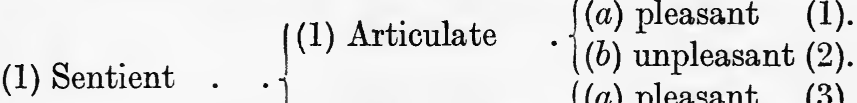

(2) Inarticulate . $\{(a)$ pleasant (3).

(b) unpleasant (4).

(2) Non-sentient

(1) Articulate .\{ $(a)$ pleasant (5).

(b) unpleasant (6).

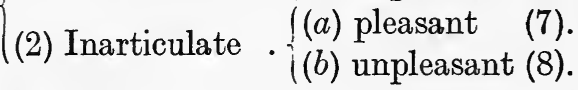

3. Gandha, or Smell.-This has only four classes: (1) Sugandha, or pleasant; (2) Durgandha, or unpleasant; (3) Samagandha, lit. similar smell, but which is interpreted as meaning smell which renders nourishment to the body; (4) Visamagandha, dissimilar smell, or smell which does not render nourishment to the body.

4. Rasa, or Taste.-This consists of six classes: (1) Madhura, or sweet; (2) Āmla, or sour; (3) Lavaṇa, or brackish ; (4) Kațuka, or acrid ; (5) Tikta, or bitter ; (6) Kașāya, or astringent.

5. Sparśa, or Touch.-This consists of eleven classes, viz. : (1) Pṛithivi, or earthy; (2) Āpas, or watery ; (3) Tejas, or fiery; (4) Vāyu, or airy; (5) Ślakṣnatva, or smooth ; (6) Karkaśatva, or rough ; (i) Laghutva, or light ; (8) Gurutva, or heavy; (9) Sita, or cold ; (10) Jighatsā, or hunger ; (11) Pipāsā, or thirst.

\section{(iii) Atoms and Molecules}

In the preceding pages frequent mention has been made of the terms atoms and molecules. It is therefore expedient to examine more closely the Buddhist atomic theory.

While frequent mention is made of the four Mahābhūtas, neither the Pali sūtras nor the seven Pali Abhidharma works contain any mention of the atomic theory, and the idea seems to have been introduced into Buddhism by the Sarvāstivādins, probably as the result of contact with the Vaiśeșikas, for the 
Jain atomic theory, like that of the Buddhists, seems a borrowed and not an original doctrine. I have been unable to find any reference to atoms or molecules in the Jñāna Prasthäna, nor in any of the six pada, which with them constitute the original Abhidharma canon of the Sarvāstivādins.

The Mahāvibhāșa, however, probably composed in the early part of the second century A.D., makes frequent mention of the atoms in its interpretation of the older works, and seemingly with no sense of incongruity. That it was quite prevalent at this time is seen from the fact that the Abhidharma Hridaya, translated into Chinese in the third century A.D. (one of the earliest Abhidharma works to be translated), contains the whole theory in its developed form. The atomic theory plays an integral part in the philosophy of Vasubandhu and Sanghabhadra. The early and classical Yogācārins, moreover, accept the theory provisionally in spite of their idealism. The later Yogācārins, however, beginning with Dignāga, felt that the doctrine stood in the way of the doctrine that all phenomena spring from the mind, and in his Álambana pratyaya Dignāga wrote a very able refutation of the atomic theory.

The Neo-Sthaviravādin school founded by Buddhaghosa does not seem to have gone, at first, into details of the atomic theory as found in the north, but the kalāpa theory (corresponding to the Sarvāstivādin Saṃghāta paramāṇu) was used by Buddhaghosa himself in the Attha Sālinī, and was thereafter considered an integral part of the Sthaviravādin philosophy, the idea being mentioned and considerably developed in the Abhidhammattha-Sangaha. At a somewhat later time (when, I do not know) the ultimate units of the kalāpa or molecule received the name paramānu, and Professor Maung Ting tells me that at the present time it is considered an integral part of Sthaviravādin philosophy.

1. Atoms.-The Sarvästivädins (Ab. Hr. 1, etc.) tell us that there are fourteen kinds of atoms, just as the scientist 
at least of a generation ago would have said that there are eighty odd kinds of atoms, one kind for each element. The number fourteen is accounted for by one being given to each of the sense organs, and one to each of the sense objects, and four additional ones for each of the four Mahābhūtas.

Unlike the atoms of the Vaiśeșikas and Jains, however, the atoms of the Buddhists are not eternal. They spring into being from time to time, and then are destroyed, lapsing seemingly into nothingness (cf. A.K. 12, latter half). Thus, the atoms of the five sense organs and sense objects originate owing to the atoms of the four elements, and would instantly lapse into decay were it not for the sustaining power of the elemental atoms. Hence every derivative atom has with it, sustaining it, one atom of each of the Mahābhūtas. ${ }^{1}$ Even these mahābhūmika atoms, however, are not themselves permanent, but undergo a four-fold process of birth continuance, decay, and destruction, followed by a new cycle of birth, etc. This phenomenalist view of the atoms is of interest as a contrast to the substantive view of the atoms held by their Indian contemporaries.

2. The Molecules.-These atoms are grouped together into molecules, and all parts of the material universe consist of these molecules, called Samghāta paramāṇus by the Sarvāstivādins, and kalāpas by the Sthaviravādins.

Vasubandhu tells us that the molecules of non-sentient matter are the simplest, and that even these are at least eight-fold, i.e. containing at the very least atoms of each of the four elements and four of the sense objects, atoms of sound not being necessarily included. Where a sound atom is produced by the action of the other atoms, the molecules are then nine-fold. Strictly speaking, even an eight-fold molecule contains at least twenty atoms, since there are four sense object atoms and each such derivative atom must have one atom of each of the four elements supporting it, making four 
derivative and sixteen elementary atoms in the simplest molecule. This number is increased to five derivative and twenty elemental atoms in the case of those molecules containing sound atoms. The number eight or nine there refers only to the different kinds of atoms in a molecule, and not to the total number of constituent atoms.

The molecules of every animate body is more complicated. Every such molecule must contain at least nine kinds of atoms, for in addition to the foregoing necessary eight, each molecule contains an atom of the kāya indriya, or touch sense organ. The molecules of the sense orifices (eye, ear, nose, etc.) are at least ten-fold, for such a molecule must contain not only the four elemental atoms, four sense object atoms, and a kāya-indriya atom, but also an additional atom of the sense organ in question.

Since the Neo-Sthaviravādins retained the whole twentyeight divisions of rūpa of the old Pali Abhidharma, their list of the component parts of a molecule differs somewhat from the preceding. Those who are interested in the subject will find particulars in Abhidhammattha Sangaha (C.P. 164, seq.).

(iv) The Eleventh Category of the Northern Schools

Before closing our discussion of the divisions of rūpa or matter as known to the Buddhists, we must examine the two as yet unexplained categories, namely, the Avijñapti rūpa of the Sarvāstivādins, and the mentally perceived matter of the Yogācārins.

1. Avijñapti was a term of much dispute among the Buddhists, and there were even widely diverging opinions as to the general group under which this particular category should come. The term means " not manifested", or not expressed, or latent. According to the Buddhists, every physical act, word, or thought should have some corresponding result. In many cases the result was open and obvious. An act visibly modified the nature and position of the molecules. Sometimes, however, no such manifested (vijñapti) result 
would be observed. The moral theory of the Buddhists would not allow them to suppose that such an action had no result, even though no result were visible, so they invented the category of Avijñapti, which we may say corresponds to the Western idea of the general character of a man, inasmuch as the general character of a man is affected by his past actions, even though it seems to have no result.

This general character was affected by not only definite conscious acts, but also by acts performed unconsciously or in a state of confused thought. On the other hand, for the action to have effect it must be definitely good or bad. This general character, moreover, was of a very general nature, constantly changing and yet remaining with one through the whole course of one's life.

So far, the Northern Buddhists of all schools seem to have been in agreement, but in attempting to give a definite place to this dharma, dispute arose. Harivarman's Sattvasiddhi insists that it must be relegated to the Citta-viprayukta, or miscellaneous dharmas neither mental nor physical. The T'ien T'ai and the Hua-yen schools of Chinese Buddhism said that the character arising from physical and verbal action was material (rūpa), but that mental action was not. The Yogācārins stated that conventionally, or from the relative standpoint, all three might be called physical. The Sarvāstivādins, however, claimed that all such character is ultimately material, and dependent upon the four mahäbhūtas. In consequence, they classified this dharma as the eleventh of their material factors. (For further details of the Sarv. theory, A.K. 1-8b; also the first half of 13, on Avijñapti karma.)

2. The material properties classified under mental object. ${ }^{1}$ The first ten dharmas, including the four mahābhūtas, the five sense objects, and the five sense organs, all belong to the realm of sensuous or immediately experienced matter. In addition, however, there are certain aspects of matter of

$$
1 \text { A.S.S., f. 1, p. } 26 .
$$


which we have no sensuous knowledge, and which are not the objects of the five sense organs but of the mind. Thus, atoms, etc., cannot be seen, they can only be inferred. The Yogācārins have placed in a separate category all those aspects of matter which are thus defined, whether these aspects be objectively existent or merely the result of mistaken creative imagination on the part of the mind. This includes, but is not confined to, the Avijñapti rūpa of the Sarvāstivādins, and constitutes the eleventh category of the Yogācārins.

\section{CitTa, OR Mind}

Having completed our survey of the Buddhist theory of matter, let us now examine their theory of the mind. This is, as we have seen, discussed in a two-fold way in Buddhist books : (1) Mind itself in its various divisions, known as Citta or Vijñāna ; and (2) mental qualities evoked by mind in the process of its origination, and which are known as Caitasikas.

In the present instance we are concerned with the first alone. But in order that we may understand the various types of mind enumerated by the Buddhists it is necessary, once more, to emphasize the caused and conditioned nature of all mentation. Buddhist books are constantly repeating the Buddhist adage that there is not ego entity, no selfexisting mentator, and that not only is the mentating personality evoked by a combination of causes and conditions, but also that mind ceases to exist when sense object and sense organ cease to interact. Strangely enough, even the Yogācārins, who were idealists, refused to believe in a permanent individual mind-substance, but stated that though mind is the only ultimate reality, every individual mind is constantly changing and being remodelled under the influence of causal law.

All this, of course, is in accord with the curious antisubstantialist position assumed by Buddhism all along the line. There is no eternal self-existing matter. Likewise there 
is no eternal self-existing quiescent substance known as mind having a prior existence and which is merely stimulated into activity when brought into contact with the sense objects by means of the sense organs. Rather, certainly according to Hīnayāna Buddhism, is it a definite product created out of nothing by the interaction of the indriyas and vișayas.

This consideration is important, inasmuch as many of the so-called divisions of mind are types of mentation classified in accordance with the nature of the stimulus which brought them into being. Consequently, we find two different methods of classification. One is according to the physical basis from which mentation arises. This method of classification is common to all forms of Buddhism, including the three schools with which we are at present more particularly concerned. The other method of classification is more complicated, and deals with all possible states of mind which can arise at any given place, e.g. on earth, the Rūpa dhātu, etc., or with the conditions (as opposed to the bases) under which they arise. This latter mode of classification seems to be peculiar to the Sthaviravādin school. Possibly, the clumsiness of the Southern list caused the philosophers of other schools to think such attempts at classification ill-advised.

\section{Mind Classified according to the Bases which Evoke it}

Before proceeding to consider the divisions of the mind, however, it will be well to take into consideration the different terms that are used for mind, and see what they mean. Apart from Nāma (name) in the compound Nāma-Rūpa, which covers the whole of the non-material part of the human personality, there are three terms which are most frequently employed. These are Citta, Manas, and Vijñāna. ${ }^{1}$ Western scholars have not yet come to a standard translation of these important words, but provisionally we may say that Citta is mind, Manas is reason, and Vijñāna is consciousness.

1 See discussion of each term, A.K. 4-13a. 
Citta, the Buddhists derived, probably wrongly, from Citra, or variegated (Exp., 1-85), a term which the Chinese render 集起, or arising by compounding. This derivation was probably given by way of added emphasis to the doctrine of the non-substantial nature of the mind. The term is very little used in the sūtras, but came to be the standard word in later days for the whole of the subjective life, as opposed to rūpa or even to the Caitasikas, and in some ways corresponds to our "soul", "heart", or "spirit", provided that all these terms are de-ätmanized.

Manas, the Buddhists derived from a term to measure (mā). It implies the calculation, evaluating, judging of a thing. Consequently, it is frequently used when the mind is considered a reasoning factor. When used technically, therefore, we may call it Reason, but frequently it, like.Citta, may be rendered Mind. It is interesting to note, however, that when the Mahāyannists say that the whole universe is but the creation of Mind, or that nothing exists outside the "mind", it is Citta and not Manas that is used. Very occasionally Vijñāna takes the place of Citta in this connexion.

Vijūana is perhaps the oldest of the three terms, and in the early sūtras, when the reincarnating personality is spoken of, it is Vijñāna and not Manas, or even Citta, that is mentioned. In later times, however, it came to be used almost exclusively for the sensatory, experiencing aspect of the mind. In this way Citta, or the mind as a whole, is said to be divided into so many Vijñānas or types of data-receiving forms of cognition.

In the midst of all this confusion, it is agreeable to find that the Buddhists, at least the Sarvāstivādins and Sthaviravādins, agree that there is only a difference in terminology, and that the thing spoken of is the same (C.P. 234 ; A.K. 4, 13). The slightly different use of the terms by the Yogācārins will be dealt with presently.

As regards the actual number of divisions of Vijñāna, the Sthaviravādins and the Sarvāstivādins ${ }^{1}$ are in agreement

1 A.K., 1-16, for full discussion. 
in postulating but six, as opposed to the eight divisions of the Yogāaarins. The six-fold division need not detain us long, for it has already been discussed in connexion with the dhātus and the fifth skandha. There is one vijñāna for each of the five material sense organs, and one vijñāna (Mano-vijñāna) of a more general character, which exercises the functions of reason, judgment, memory, planning, etc. In addition to the other differences between the first five Vijñānas and Mano-vijñāna which have already been given, the Buddhists assert that the former are purely passive, while the latter is active. Consequently, while certain phases of the former may come under the category good or bad, it is only because they have been influenced in a moral or immoral way by the former. Again, only a small number of the Caitasikas are associated with the first five vijñānas, while all of them are to be found in association with the Mano-vijñanna.

One of the points on which Buddhism is singularly obscure is the psycho-physical relation between the first five vijñānas and the all-encompassing Mano-vijñāna. The early works do not state where the first five vijñannas are, but by their close association with the sense organs it is implied that they are actually resident in them. This idea was expressly stated in later times (cf. Spence Hardy, Man. Bud., p. 434). Concerning the physical basis of the Mano-vijñāna, there is even greater ambiguity. The Sarvāstivādin knows of no physical basis, the sense organ of Mano-vijñāna being Manas, or the whole of the disintegrating aspects of consciousness itself. The Neo-Sthaviravädins give the physical basis of the Mano-vijñāna as the heart, but since the first five kinds of consciousness occur at the sense doors, and Buddhism knows nothing of the nervous system, we are left wondering how the Mano-vijñanna becomes aware of the impressions received by the other five. The Sarvāstivādins partly answer, or, rather, evade this question, by saying that the six vijñānas form not six dharmas, but together constitute only 
one dharma or ultimate factor, and that consequently the six vijñānas are but six aspects of one vijñāna rather than six separate entities (cf. A.K., 1-11b). This doctrine of the unity of vijñãna does not, of course, interfere with the anātman theory.

The eight-fold division of vijñāna postulated by the Yogācārins ${ }^{1}$ consists of the foregoing, plus two others. These additional two are :-

1. Klișta-mano Vijñāna, literally, soiled-mind consciousness. This may be rendered by self-consciousness (V.M.S. 4-15b). Whereas Mano-vijñāna carries on the ordinary process of reasoning, it deals with ideas more or less as they come, without consciously or continuously distinguishing between that which appertains to the self and that which appertains to the non-self. This continual distinction is the work of the seventh vijñāna, which, according to the Yogācārins, functions even when a man is asleep or is otherwise unconscious. It is the basis of the constant tendency towards the atman theory, for it falsely considers the Ālaya vijñāna (the eighth vijñana, the basis of all the other vijñānas) to be a real and permanent ego entity, although in reality it is in a constant state of flux.

2. Ālaya Vijñāna means repository consciousness, since it is the basic form of all other consciousness, and, in fact, of all forms of existence. All the other vijñänas have their origin in the Ālaya vijñana, and owing to their activity the construction of the phenomenal world takes place. This is not the place to discuss the whole of the idealistic philosophy of the Yogācārins, but mention must be made of the triple function of the Ālaya vijñāna. The first we can call the positive (能 藏 nêng ts'ang), because it stores up the seeds of all the other vijñanas. The second we can call the negative (所 藏 so ts'ang), because it receives the influence of all the

1 The bulk of V.M.S. consists of a full discussion of each of these Vij. For Ālaya, pp. $6 a-15 b$; for Kl. Man. Vij., pp. 15b-21 $a$; for the First Six Vij., $21 a$ seq. 
other phenomenal vijñānas. The third is this vijñāna considered as the object of false belief, 1 because the seventh vijñāna constantly considers that this ever-changing Ālaya vijñāna is an eternal ego entity. ${ }^{2}$

In accordance with their postulation of three kinds of mental activity not immediately connected with the senses (Mano-, Klișța-mano-, and Ālaya-vijñānas), the Yogācārins slightly modify the old definitions of Citta, Manas, and Vijñāna. All three terms, say the Yogācārins, may be used of any of the eight aspects of consciousness, but more especially does the eighth or Ālaya vijñanna take the title Citta; more especially does the seventh vijñāna receive the title of Manas; while Vijũāna applies more particularly to the sixth vijñāna. (Cf. Wei shih lun chêng $i,{ }^{3}$ a well-known commentary on the V.M.S., where, p. 48 seq., the matter is discussed at length.)

Finally, we may add that, whereas the Sarvāstivādins count their six vijñānas together as forming but a single dharma in their list of seventy-five, the Yogācārins count each of the eight vijñanas separately in making up their list of a hundred dharmas. This fact, however, may be easily misunderstood. It is not that the Sarvāstivādins believe in the unity of the mind more than the Yogācārins, but rather that according to the Yogācārins there is in reality only one substance-Mind, of which all other things are derivatives, and since it attempts to enumerate all the important derivatives, it gives each of the vijñānas a separate place.

2. Classification of the Mind, according to its Place and Condition

This elaborate classification of the mind plays, a very important part in the Sthaviravādin Abhidharma works, but it seems to be confined to this school. Consequently, while it is necessary to give this list, it is not essential that we should go into great detail about the matter.
1 執 藏.
2 V.M.S. 2-6b.
3 唯識論證義. 
A few preliminary remarks, however, will not be out of place. The full list consists of eighty-nine dharmas, but within this number certain main types of classification can be discerned. 1

1. Consciousness classified according to whether it appertains to the Kāma, Rūpa, or Arūpa dhātus.

2. Consciousness classified according to whether it is active, passive, or neither. This means: $(a)$ active $=$ that which engenders karma for the future ; $(b)$ passive = consciousness which comes into being as the result of past Karma; (c) neither $=$ consciousness which, though active, leads to no further rebirth and may, therefore, be considered inoperative. This refers to the actions of the Buddha, Pratyeka Buddhas, and Arhats, who are free from the wheel of birth and death.

Each of these categories may be several times subdivided :-

1. Active Consciousness is divided into meritorious and demeritorious. Meritorious is divided into that which appertains : (i) To the kāma dhātu ; (ii) to the rūpa dhātu ; (iii) to the arūpa dhātu; and (iv) transcendental state or emancipation. Demeritorious is divided into only one category, that which appertains to the kāma dhātu, but this is subdivided into (i) that rooted in greed; (ii) that rooted in batred ; (iii) that rooted in ignorance.

2. Passive Consciousness is likewise divided into $(a)$ that appertaining to the kāma dhātu, $(b)$ the rūpa dhātu, $(c)$ the arūpa dhātu, and (d) transcendent. Kāma dhātu, resultant consciousness, is likewise divided into (i) meritorious, the result of previous good karma, and (ii) demeritorious, the result of previous bad karma. (i) is again subdivided into $(a)$ associated with hetu or root conditions, and $(b)$ dissociated with hetu or root conditions.

This method of classification having been once clearly understood, the accompanying chart giving the whole eighty-nine divisions of consciousness will become intelligible.

1 Cf. first part of C.P., p. 81 ff., and Book I of R.D. trans. Dh.S., pp. 1-165. 


\section{Caitasika Dharmas or Mental Properties ${ }^{1}$}

We now come to a classification of the various phases of mental activity which Buddhism believes to be fundamental. To us the fact that the Buddhists gave these items a place in their list of separate and ultimate factors of life may cause some surprise. We should have expected them to be classed as subdivisions of Citta in much the same way as the six, eight, or eighty-nine fold division of vijñāna. This, however, would be inconsistent with the Buddhist non-substantialist position. Other schools of thought might consider these caitasikas to be not separate entities but qualities inherent in a simple substance such as mind, but to the Buddhists this savoured too much of àtmanism and substantialism. Wherever possible, Buddhism was determined to make qualities into separate entities or dharmas, and though the Caitasikas were necessarily co-ordinate with the mind (citta), they were independent co-products of the interaction of the sense objects and sense organs, and not merely inherent, dependent qualities.

The Sarvāstivādins were especially insistent upon their separation and independence, and with them we may be certain that what was enumerated in their list of seventyfive dbarmas was not co-incidental with anything else, for they refused to count any entity twice over, as may be seen from their refusal to count citta as six-fold. (For the fact that every dharma given in their list of seventy-five was distinct, see among many other passages, the discussion on the Cittaviprayukta dharmas, A.K. 4, latter half ( $13 b$ to end), and also the discussion of Moha, A.K. 10-1.)

With the Yogācārins, the Caitasikas along with the other dharmas, were not separate entities, but only real phases of the one true entity, mind, ${ }^{2}$ and even the later Sthaviravādins

1 For Sth. cf. C.P., part ii, pp. 94-110; also incidental lists in Book I of Dh. San. For Sarv. Dh. Kāya f. 1 ; A.K., $4-2 b$ to $13 b$; N.A. 10-30a ff. For Yog. all Sat. dh. and P. Sk. ; A.S.S. 1-3a ff. ; V.M.S. 5-22a ff.

2 V.M.S. $1-5 b$. 
seem to accord a certain relative unity to the Citta and Caitasika dharmas, where Citta is sometimes said to be considered as a sphere and Caitasikas as its separate sections.

One other thing has to be borne in mind in this connexion. These Caitasikas do not pretend to be a list of all mental complexes which may be found in an individual. Rather are the Caitasikas the elements of which these complexes are composed, and just as the four mahābhūtas and the five sense object atoms may combine in an infinite number of ways to form the complex external world around us, so may the various Caitasikas be compounded in an infinite number of ways, ranging from the simple thoughts and desires of a child to the most abstruse metaphysical inference (cf. C.P. 237 seq.).

Now a word as to the main groups into which the Caitasikas may be divided. All schools are agreed that there must be at least three such groups, ${ }^{1}$ viz. :-

1. General mental properties which are neither meritorious nor demeritorious.

2. Meritorious mental properties.

3. Demeritorious mental properties.

1. General Mental Properties.-The Sarvāstivādins do not further divide this group, but the Sthaviravādins (at least, the Neo-Sthaviravādins) and the Yogācārins state that there are two kinds of general mental properties: (i) universal mental properties, which are found in every form of mental activity and common to all forms of vijñāna; and (ii) particular mental properties, which are found only under certain conditions and limited to a certain type of vijñāna.

2. Meritorious.-The Yogācārins and Sarvāstivādins do not divide this group, but the Sthaviravādins usually introduce a rather pragmatic four-fold division.

3. Demeritorious.-The Sthaviravādins do not divide this category, but the Sarvāstivādins and Yogācärins go into great detail. The Sarvāstivādins give the following three groups:

1 Further details in authorities cited above. 
(1) The fundamental kleśa dharmas; (2) the Akuśala or positively demeritorious dharmas, which are also fundamental or non-derivative; and (3) the Upakleśa dharmas or subsidiary kleśas, derived from the dharmas of the preceding two categories. Of the two categories, Müla-kleśa and Akuśala, the latter is the more positively evil.

The Yogācārins, on the other hand, only make a distinction between the fundamental kleśas and the subsidiary kleśas, though, as we shall see later, they introduced several internal subdivisions, particularly as regards the second category.

4. Indeterminate.-In the Sthaviravādin school all of the Caitasikas were included in one or other of the preceding three categories, but both the Sarvāstivādins and Yogācārins added a fourth group, consisting of those dharmas which are indeterminate and which may be either meritorious or meritorious according to circumstances, or which for other reasons can come under none of the preceding heads.

From the preceding remarks, it will be seen that the Sarvāstivādins ${ }^{1}$ had the following arrangement of the Caitasikas :-

1. Mahäbhümika dharmas, or general mental properties, ten in number.

2. Kuśala-mahäbhūmika dharmas, or mental properties common to all types of meritorious mental activity, ten in number.

3. Kleśa-mahābhümika dharmas, the fundamental passions or afflictions, six in number.

4. Akuśala-bhümika dharmas, or evil mental properties, two in number.

5. Upakleśa-bhümika dharmas, the subsidiary passions derived from the preceding two categories, ten in number.

6. Avyākrta-bhümika dharmas, or miscellaneous mental properties, eight in number.

1 A.K. 4-3a. 
The Yogācãrin ${ }^{1}$ arrangement was as follows :-

1. Universal mental properties, common to every act of consciousness, and neither meritorious nor demeritorious, five in number.

2. Particular mental properties, found only in certain types of mentation, but neither meritorious nor demeritorious, five in number.

3. Meritorious mental properties, eleven in number, all of them fundamental.

4. Fundamental Kleśas, six in number (demeritorious).

5. Subsidiary Kleśas, twenty in number (demeritorious).

6. Indeterminate mental properties, four in number.

The Sthaviravādin ${ }^{2}$ classification was:-

1. Universal mental properties, seven in number.

2. Particular mental properties, six in number.

3. Demeritorious mental properties, fourteen in number.

4. Universal meritorious mental properties, nineteen in number.

5. The Abstinences, three in number (meritorious).

6. The Illimitables, two in number (meritorious).

7. Reason (meritorious) (1).

Before we can go into further details concerning general relationships it will be necessary to enumerate the constituent dharmas of each of the categories.

\section{General Mental Properties}

A. The Sarvāstivādins made no distinction between the universal and particular, or rather they believed that all of the following dharmas are universal. They $\operatorname{are}^{3}$ :-

1. Vedan $\bar{a}$, or feeling.

2. Sainjū $\bar{a}$, or ideation.

3. Cetana $\bar{a}$, or volition.

4. Sparśa, or sensation.

1 V.M.S. 5-22a. $\quad 2$ C.P., p. 98, mnemonic verse. $\quad 3$ A.K. 4-3b. 
5. Chanda, or will or conation.

6. Mati, or intelligence, or wisdom, or reason.

7. Smrti, mindfulness or memory.

8. Manaskāra, attention, or mental excitation.

9. Adhimokșa, deciding, or determining.

10. Samādhi, or concentration.

Vasubandhu tells us that there is no logical order in the above arrangement, and that one may be placed before or after the other (A.K. 4-4a).

B. The Yogäcärins ${ }^{1}$ were more logical and systematic in their method of enumeration. Not only did they divide the above ten into five which are universal and five which are particular, but the order of enumeration was also supposed to be based on the logical process of thought.

The five universals are :-

1. Manaskāra, or attention, or preliminary mental excitation.

2. Sparśa, or resultant sensation.

3. Vedanā, or feelings aroused by sensation.

4. Samjñ̃ā, or ideation, the framing of concepts as the result of feeling.

5. Cetanā, or volition, the wishing to meet or avoid further such experiences.

The five particulars are :-

1. Chanda, or will, or desire to act, more deep-seated and determined than Cetanā.

2. Adhimokșa, deciding, or the definite placing of the object in certain categories, and determining to act accordingly.

3. Smrti, mindfulness, or memory, and deep and clear impression of an object as opposed to the more transient nature of the preceding categories, and enabling the image of the object to be recalled at will (volitional), or by the association of ideas (automatic). 
4. Samādhi, or concentration, the singling out of a single object or notion and remaining fixed upon it.

5. Mati, or intelligence, or wisdom. This is the reasoning power whereby we can frame rational notions as opposed to the more automatic samjñna, which serves merely to give an object a name.

C. The Sthaviravādins ${ }^{1}$ prepared the following list :There are seven universals :-

1. Sparśa (passa), or sensation.

2. Vedanā (vedanā), or feeling.

3. Samjjñā (saññā), or ideation.

4. Cetanā (cetanā), or volition.

5. Ekāgratā (ekaggatā), or individuality of object (= samādhi).

6. Manaskāra (manasikāra), or attention.

7. Jivitendriya (jīvitindriya), psychic life or vitality.

There are six particulars :-

1. Vitarka (vitakka), inquiry or initial application of the mind.

2. Vicāra (vicāra), investigation or sustained application of the mind.

3. Adhimokșa (adhimokkha), or deciding.

4. Virya (viriya), effort or energy.

5. Priti (piti), zest or pleasurable interest.

6. Chanda (chanda), will or desire to act.

The Sarvāstivādins and the Yogācārins have the same dharmas, even though the arrangement is different. There is a difference, however, between the Sarvāstivādins and Yogācărins on the one hand and the Sthaviravādins on the other. The former have only ten general dharmas, as opposed to the thirteen of the latter. The Jivitendriya or vitality of the Sthaviravādins is placed by the former schools among the Citta-viprayukta dharmas, and not among the Caitasikas.

1 C.P., pp. 94-5. Here, and generally speaking elsewhere, I have restored the words to Skt. in order to facilitate comparison with the northern list, the Pāli forms being added in parenthesis. 
Vitarka and Vicāra are placed by them among the Avyākrta or indeterminate Caitasikas. This brings the Sthaviravādin list down to ten. But Priti is considered in the North a variety of joy (somanassa), and therefore one aspect of Vedanā, and is not therefore counted a separate dharma. In place of the priti the Northern schools have mati, or intelligence, which corresponds to the Prajñā (pañña) of the Sthaviravādins, who, however, place it not among the general but among the meritorious mental properties. The Sthaviravādins, likewise, reserve the term samādhi for the higher forms of concentration, and give the term Ekāgratā for ordinary concentration.

\section{Meritorious Mental Properties}

A. The Sarvāstivādins ${ }^{1}$ enumerated the following ten dharmas as members of this category:-

1. Śraddhā, faith or devoutness.

2. Apramāda, carefulness or self-control.

3. Praśrabdhi, serenity or cheerfulness.

4. Upekșā, equanimity or indifference.

5. Hrī, or shame (at doing an evil action).

6. Apatrapā, or humility.

7. Alobha, or absence of cupidity.

8. Adveșa, or absence of hate.

9. Ahimsā, or compassion, or harmlessness.

10. Virya, or effect, or energy.

B. The Yogācārins ${ }^{2}$ have the same ten, but have added an additional dharma, Amoha, or enlightenment (non-stupidity), which the Abhidharma Kośa believes to be identical with the Mati of the preceding category, and so does not list as a separate entity. The order of enumeration, however, is somewhat different, and is as follows :-

1. Sraddhā, or faith.

2. Virya, or energy.

3. Hrī, or shame.

4. Apatrapā, or humility.

1 A.K. 4-4a; N.A. 11-16a.

${ }^{2}$ V.M.S. 6-24a. 
5. Alobha, or absence of cupidity.

6. Adveșa, or absence of hate.

7. Amoha, or absence of ignorance.

8. Praśrabdhi, or serenity.

9. Apramāda, or carefulness.

10. Ahimsā, or harmlessness.

11. Upekșā, or indifference.

It will be observed that this arrangement contains the opposites of all of the three fundamental roots of evil, the famous lobha or cupidity, dveșa or hatred, and moha, ignorance.

C. The Sthaviravädin ${ }^{1}$ enumeration differs considerably from both the above lists, and is far more elaborate and involved, even though less scientific and logical. The various meritorious dharmas are arranged in four groups, as follows :-

(i) Prajñā (paññā), wisdom or reason.

(ii) The Illimitables :-

1. Karuṇa (karuṇā), or pity (= ahimsāā).

2. Mudita (muditā), or appreciation.

(iii) The Abstinences :-

1. Right speech.

2. Right action.

3. Right livelihood.

(iv) General Meritorious Mental Properties :-

1. Sraddhā (saddha), or faith.

2. Sṃrti (sati), or mindfulness.

3. Hrī (hiri), or shame.

4. Apatrapā (ottappa), or humility.

5. Alobha (alobha), or absence of cupidity.

6. Adveșa (adosa), absence of hate.

7. Tatramadhyasthatā (tatramajjhattatā), or balance of mind (= upekșā). 
8-9. Praśrabdhi (passaddhi) of citta or mind, and kāya, ${ }^{1}$ mental properties.

10-11. Laghutā (lahutā), or buoyancy of citta and kāya. 12-13. Mridutā (mudutā), or pliancy of citta and kāya. 14-15. Karmanyatā (kammaññatā), or fitness to work of citta and kāya.

16-17. Pragunatā (pagunatā), familiarity of citta and kāya.

18-19. Rijukatā (ujukatā), or rectitude of citta and kāya. Comparing the Northern, or Sarvāstivādin, and Yogācārin list with that of the South, we have already remarked that Smṛti changes places with vīrya. Karunā and muditā take the place of the single dharma ahimsā, so that the only dharmas contained in the Sthaviravädin list which are not also found in the North are the three illimitables, and categories 10-19 of the general meritorious dharmas, while, on the other hand, of the Northern list only Apramāda is ignored in the South.

\section{Demeritorious Mental Properties}

Here matters become more complicated, and owing to the greater subdivision of the Northern accounts it is better to reverse our usual procedure, and give the Sthaviravädin ${ }^{2}$ enumeration first. This consists of :-

1. Moha (moha), or ignorance.

2. Ahrīkya (ahirikā), or shamelessness.

3. Anapatrapya (anottappa), or impudence.

4. Auddhatya (uddhacca), recklessness.

5. Lobha (lobha), or cupidity.

6. Drșți (dițthi), erroneous views.

7. Māna (māna), pride.

8. Dveșa (dosa), ill-will.

9. Irșyà (issā), envy.

10. Matsarya (maccharya), selfishness.

1 That Kāya here means mental properties is to be seen from C.P. 96 note.

C.P., pp. 95-6. 
11. Kaukrtya (kukkucca), remorse, worse.

12. Styāna (thīna), sloth.

13. Middha (middha), torpor.

14. Vicikitsā (vicikiccā), perplexity, doubt.

The Sarvāstivādins ${ }^{1}$ adopted the following arrangement of the demeritorious Caitasikas :-

A. Fundamental Kleśas :-

1. Moha, or ignorance.

2. Pramāda, or carelessness.

3. Kausidya, or inattention to what should be done.

4. Aśraddhā, or lack of faith.

5. Styāna, or sloth.

6. Auddhatya, or recklessness.

These may be either positively demeritorious (akuśala), i.e. leading directly to painful consequences, or obscuring neutral (有覆 無 記), indirectly leading to painful results.

B. Akuśala Dharmas ${ }^{2}$ :-

1. Ahrīkatā, or shamelessness.

2. Anapatrapā, or impudence.

These two are positively evil and lead directly to painful results.

C. Subsidiary Kleśas ${ }^{3}$ :-

1. Krodha, or anger.

2. Mrakșa, or hypocrisy.

3. Matsarya, or selfishness.

4. İrsyā, or envy.

5. Pradāsa, gloom or dissatisfaction.

6. Vihiṃsā, or shamefulness.

7. Upanāha, or enmity.

8. Māyā, or deceit.

9. Śäthya, or dishonesty.

10. Māda, or arrogance.

1 A.K. $4-5 a$; N.A. ii, $7 b$.

2 A.K. 4-6b; also 21-4b; N.A. 6-8b.

3 A.K. $4-7 a$; N.A. $6-9 b$. 
These subsidiary kleśas have four qualities peculiar to themselves, ${ }^{1}$ i.e. though other caitasikas may possess one or more of these qualities, only the upakleśas possess all four. These are :-

1. They are to be got rid of only by cultivation, and not by intellectual insight.

2. They are associated only with Mano-vijñāna, and not with the other five vijñānas.

3. They are all associated with ignorance.

4. They may arise separately, and are thus not necessarily conjoined.

The Yogācārin enumeration ${ }^{2}$ of the demeritorious Caitasikas is as follows:-

\section{A. The Fundamental Kleśas :-}

1. Lobha, or cupidity.

2. Dveșa, or hatred or ill-will.

3. Vicikitsā, or doubt.

4. Māna, or pride.

5. Moha, or ignorance.

6. Asamyag-drsți, or erroneous views, which are of five types, sometimes enumerated as separate dharmas.

We see how widely the Sarvāstivādin and Yogācārin enumeration of the fundamental kleśas differs, even though both lists agree in giving six dharmas. Five of the dharmas which the Sarvāstivādins regard as fundamental are placed among the subsidiary kleśas by the Yogācārins, so that only one of the Sarvāstivādin fundamental kleśas (Vicikitsā) remains. To fill up this gap the Yogācārins have taken four dharmas, which the Sarvāstivādins regard as Avyākṛta or indeterminate dharmas, and enumerated them as fundamental kleśas. These are Lobha, Mana, Dveșa, and Moha. Incidentally, this classification is much more in

1 八 宗綱 要 講 義, 1-102.

2 V.M.S. $6-25 b$; A.S.S. $1-4 a$. 
accord with the general spirit of Buddhism; this gives us five dharmas. The sixth kleśa, Asamyag-drsțit, or erroneous views. The Abhidharma Kośa considers but a negative phase of Mati, and so does not consider as a separate dharma.

B. The Subsidiary Kleśas ${ }^{1}$ :-

1. Krodha, or anger.

2. Upanāha, or enmity.

3. Mrakșa, or hypocrisy.

4. Santāpa, gloom, vexation (= pradāsa).

5. Kärpanya, or selfishness (= matsarya).

6. İrsyā, or envy.

7. Sāṭhya, or dishonesty.

8. Māyā, or deceit.

9. Vihimsāa, or harmfulness.

10. Mada, or arrogance.

11. Ahrïkya, or shamelessness.

12. Anapatrapya, or impudence.

13. Styāna, or sloth.

14. Auddhatya, or recklessness.

15. Aśraddhā, or lack of faith.

16. Kausidya, idleness or remissness.

17. Pramāda, or carelessness.

18. Muṣitasmrititā, or forgetfulness.

19. Vikșepa, or confusion.

20. Asamprajñā, or wrong judgment.

Comparing the Sarvāstivādin and Yogācārin lists of these subsidiary kleśas, we find that the Yogācārins bave adopted all ten of the Sarvāstivādin lists (Nos. 1-10), and have, further, included the two Akuśala dharmas of the Sarvāstivādins. Again, the four dharmas which the Yogācārins ejected from their place among the fundamental kleśas are here given a place (Nos. 13, 14, 15, 16, 17). As regards the last three items of the Yogäcārin list, the Abhidharma Kośa ${ }^{2}$ mentions them as being included in

1 V.M.S. 6-27 ; A.S.S. 1-4b.

$24-5 b$. 
some accounts, but rejects them as being but subdivisions of Mati.

A comparison of the Northern and Southern lists shows how different the line of development of the two traditions has been. These differences, however, call for little or no remark.

\section{The Indeterminate Mental Properties}

This category, as we have seen, is not found among the Sthaviravādins, and is therefore peculiar to the Northern schools.

The Sarvāstivādins ${ }^{1}$ enumerate eight such dharmas :-

1. Vitarka, inquiry or initial application.

2. Vicāra, investigation, or sustained application.

3. Kaukrtya, remorse or worry.

4. Middha, or torpor.

5. Rāga, or greed (= lobha).

6. Pratigha, or ill-will (Dveșa).

7. Māna, or pride.

8. Vicikitsā, perplexity or doubt.

The Yogācārins have but four such dharmas, and these are jdentical with the first four of the Sarvāstivādin enumeration. The remaining four of the Sarvāstivādin list have been put among the fundamental kleśas by the Yogācārins. $^{2}$ It has already been seen that by the Sthaviravādins Vitarka and Vicāra are placed among the particular general Caitasikas, while the other members of this category are placed by them among their ordinary demeritorious Caitasikas.

\section{General Discussion of the Caitasikas}

The Sarvāstivādins

The first point to be noticed is the relation between the Citta raggas and the Caitasikas, and also the functional coordination of the two groups. There was a good deal of

1 A.K. 4-7a.

2 V.M.S. 7-29a; A.S.S. 1-5b. 
difference of opinion on this subject, but most of the Sarvāstivādins were of the opinion that the function of Citta was universal, and that of the Caitasikas was particular. That is to say, Citta and the Caitasikas arise at exactly the same moment, but Citta grasps the general nature of an object, while the Caitasikas grasp each of its attributes separately, making them into a synthetic whole.

The functional relationship between the Cittas and Caitasikas must be five-fold, ${ }^{1}$ viz. :-

(1) Uniformity as regards time.-Citta and its inter-related Caitasikas arise at exactly the same kṣana, so that the Caitasikas of a past kșana are not connected with the Citta of an immediately preceding kșaṇa.

(2) Uniformity as regards basis.-Here the word basis refers to the sense organs. The Citta and Caitasika, which are called inter-related, must have originated from the same indriyas.

(3) Uniformity as regards cognized objects.-The sense objects of Citta and the Caitasikas must be the same.

(4) Uniformity as regards essence.-The essence or the essential qualities of the inter-related Citta and Caitasikas must be the same.

(5) Uniformity as regards function.-The activity of the Citta and Caitasikas must be directed along similar lines.

The preceding classification of the Caitasikas was given with reference to their essential nature, all the goods and bads being placed together. Let us now examine how these Caitasikas are grouped together in any one human or other type or personality, or, in other words, how the analytical grouping of the Caitasikas corresponds with their synthetic grouping as found in nature.

A. First as regards being residing in the Kāma dhātu. ${ }^{2}$ Apart from the more theoretical classification of dharmas into good, bad, and indifferent, the Abhidharma Kośa tells

1 A.K. 4-13a; N.A. 11-14 ; A.P. 6-11a.

2 A.K. 4-7b; N.A. 11-9. 
us that at any one time the mental state of an individual falls into one or other of the following five categories, and that each such state contains a definite number of Caitasikas. The five possible states of mind are :-

(i) Meritorious.

(ii) Simple demeritorious.

(iii) Complex demeritorious.

(iv) Obstructing neutral.

(v) Unobstructing neutral.

(i) When a meritorious state of consciousness arises, upon analysis it is found that the personality contains either twenty-two or twenty-three Caitasikas. These consist of the ten universal Caitasikas which are present in every state of consciousness, plus the ten fundamental meritorious dharmas, all of which are invariably present in every moment of meritorious consciousness, and finally vitarka and vicāra. These constitute the twenty-two dharmas which are always found. To these may be added at certain moments Kaukrtya, or remorse, making twenty-three in all. At other times this number is increased to twenty-four by the inclusion of Middha, torpor.

(ii) The simple demeritorious state of consciousness consists of those moments when the mind is rendered evil by association with moha, ignorance, but not associated with any of the other fundamental passions, such as Rāga, or covetousness, or Dveșa, ill-will. As a minimum this group contains twenty Caitasikas. These are: (1) The ten universal mental properties; (2) the six fundamental kleśas; (3) the two Akuśala dharmas ; (4) Vitarka and Vicāra (cf. A.K. 4-8).

Some schools enumerated, in addition to the simple demeritorious state composed of ignorance and its concomitants, a separate category consisting of the concomitants of evil views, but Vasubandhu refuses to let erroneous views be added as a twenty-first Caitasilka, stating, as we know, that error is but a negative phase of Mati, hence the number 
of names of the Caitasikas in a mental state associated with ignorance and one associated with erroneous views are the same. When torpor is present this category contains twentyone Caitasikas.

(iii) The complex demeritorious states of mind consist of mental groups containing other Caitasikas than those associated with ignorance. These fall into three classes :-

(a) Those states of mind where one of the four demeritorious indeterminate mental properties (Räga, Pratigha, etc.) are present. These can only arise singly, hence any mental state which contains Rāga is found on analysis to consist of the foregoing twenty Caitasikas, plus Rāga as a twenty-first.

(b) Those mental states where one of the ten subsidiary kleśas are present. These also can only arise singly, so that when a mental complex containing, say, Krodha is analysed, it is found to consist of twentyone Caitasikas, i.e. krodha and the twenty simple demeritorious caitasikas.

(c) Those mental states containing Kaukrtya, or consciousness of guilt. This also contains twenty-one Caitasikas, i.e. Kaukritya plus the usual or constant twenty.

Each of the three groups $(a),(b),(c)$ here mentioned may contain torpor, raising the total number to twenty-two.

(iv) Obstructing neutral states of mind. These are really demeritorious, but the Buddhist classes them ethically with respect to their consequences, and as these states of mind do not necessarily result directly in painful results, they are called obstructing neutral. Such states of mind contain a minimum of eighteen Caitasikas. These are: (1) The ten general mental properties; (2) the six fundamental kleśas; (3) Vitarka and Vicāra. To these may be added torpor, making nineteen in all. 
(v) Unobstructing neutral states of mind, or those which are really neither meritorious nor demeritorious. These contain a minimum of twelve Caitasikas, viz.: (1) The ten general mental properties ; (2) Vitarka and Vicāra. To this some would add a thirteenth dharma Kaukrtya. In any case torpor may be added, making either thirteen or fourteen.

B. States of mind in the higher dhātus. ${ }^{1}$ The foregoing categories explain all possible constituents of mental groups as found in the Kāma dhātu. In the two higher worlds, Rūpa and Arūpa, the arrangement of the Caitasikas is necessarily different. These may be classified as follows :-

1. The Rūpa heavens of the first dhyāna. The states of mind found in these realms can contain only thirty-four out of the forty-six Caitasikas, for twelve Caitasikas cannot arise here. The twelve which do not arise are: (1) The two Akusala dharmas; (2) the first eight subsidiary kleśas; (3) Kaukrtya, Middha, and Pratigha among the indeterminates. The thirty-four which do arise are: (1) The ten general mental properties; (2) the ten meritorious mental properties ; (3) the six fundamental kleśas ; (4) the last three subsidiary kleśas; and (5) the remaining five indeterminates.

2. The stage between the first and the second dhyānas eliminates Vitarka, but retains Vicāra and the other thirtythree Caitasikas.

3. The higher realms (from the second dhyāna up) eliminate Vicāra, Māya, and Sățhya, but retain the remaining thirty Caitasikas.

One final point in the Sarvāstivādin classification of the Caitasikas deserves attention, and that is the internal relation that exists between $(a)$ the meritorious and demeritorious Caitasikas, and (b) the fundamental and subsidiary demeritorious Caitasikas.

(a) Meritorious and Demeritorious Categories. The disparity in numbers between the good and the evil mental properties

1 A.K. 4-9b; N.A. 11-12b. 


\section{MANUAL OF BUDDHIST PHILOSOPHY}

is obvious at the first glance, for the meritorious dharmas consist of only ten Caitasikas, while the various kinds of demeritorious come to twenty-two in all. Under the head of meritorious dharmas, however, Mati, or intelligence, in the list of general mental properties may be included, so that we get the following tabulation :-

I. Meritorious

1. Mati . . . . . 1

2. The Akuśala-mahābhūmikas 10

11

II. Demeritorious

1. The Kleśa-mahābhūmikas . $\quad$. 6

2. The Akuśala-bhūmikas . . 2

3. Upakleśa-bhūmikas ․ 10

4. Among the Avyākrita dharmas . 4

Total $\quad 22$

In order to make the contrast between the two groups exact, however, the Sarvāstivādins class only eleven of the demeritorious dharmas as fundamental, while the remaining half are considered subsidiary to, or derived from, the preceding eleven, so that they are only indirectly or obliquely opposed to the meritorious Caitasikas. The eleven meritorious and eleven fundamental demeritorious Caitasikas are paired off in the following way ${ }^{1}$ :-
Meritorious
Demeritorious
1. Mati
1. Moha
2. Apramāda
2. Pramāda
3. Virya
4. Śraddhā
3. Kausidya
5. Praśrabdhi
4. Aśraddhā
Mūla Kleśa.
6. Upekșā
5. Styāna
6. Auddhatya

1 Especially Pa-tsung, 1-105. 


\section{Meritorious Demeritorious}
7. Hrī
8. Apatrapā
7. Ahrīkatā 1 Anapatrapā Akuśala.
9. Alobha
10. Adveșa
$\left.\begin{array}{l}\text { 9. Lobha } \\ \text { 10. Pratigha (Dveșa) }\end{array}\right\}$ Avyākṛta.
11. Ahimsāa
11. Vihiṃsā 1 : Upakleśa.

(b) Fundamental and Subsidiary Demeritorious Groups. The remaining eleven demeritorious Caitasikas (nine Upakleśas and two Avyakrta dharmas) are considered subsidiary, and thus only indirectly opposed to the meritorious Caitasikas. The word subsidiary, however, is used in two different senses : (1) Those which are derived from the fundamental demeritorious dharmas; (2) those which closely resemble, but are not derived from, the fundamental dharmas. The first method of classification includes only the remaining nine upakleśa dharmas. The second method of classification includes both the upakleśas and the two remaining Avyākṛta dharmas.

\section{The Yogācārins}

Limitations of space prevent our going into all the details of the Yogācāins grouping and analysis of the Caitasikas, but the following points require especial attention:-

A. Relation between Citta and Caitasikas. The Yogācārins postulate the following three points in explaining the relation between Citta and the Caitasikas.

1. The Caitasikas are connected only with Citta. In other words they have no direct connexion with any other dharma, so that Rupa cannot produce the Caitasika independent of the action of Citta. The Yogācārins suppose, of course, that all things are ultimately derived from mind, but they state that the relation between Citta and the Caitasikas is more intimate than between any other two categories.

2. Not only are the Caitasikas unconnected with any other group, such as Rūpa, but they cannot exist even as a group

1 Vihimsan is an Upakleśa, and hence a derivative dharma, but owing to its importance it is here ranked with the fundamental dharmas. 
unto themselves, so integrally are they bound up with Citta. As with the Sarvāstivādins, the Yogācārins distinguish two phases in the process of cognition : (1) The general awareness of an object; (2) the detailed awareness of each of its attributes. It is the especial function of Citta to sense the first and of the Caitasikas to sense the latter, but owing to the synthetic character of the Caitasikas, it is said that they are also connected with the former process, or to express the matter graphically :-

1. Citta . . . general cognition.

2. Caitasika . . detailed cognition.

3. The Yogācārins claim only a four-fold uniformity between Citta and the Caitasikas, as opposed to the five-fold uniformity of the Sarvāstivādins, omitting the last or uniformity of function. They explain this four-fold uniformity in the following way :-

(a) Uniformity as regards time. Both Citta and its correlated Caitasikas must arise at the same kșaṇa.

(b) Uniformity as regards basis. The Yogācārins postulate two kinds of bases for all kinds of mental activity. One is the co-existent basis, which consists of the various sense objects which are immediately present, causing both Citta and the Caitasikas to arise. The other is the antecedent basis, which consists of the groups of mentals of the preceding kșanas, which in passing out of existence transmit their energy to the new mentals just arising. The uniformity of Citta and Caitasikas as regards basis must apply to both types.

(c) Uniformity as regards cognized objects. The Yogācārins do not admit the existence of the material objects apart from the mind, so that all cognized objects are really but the ejects (相 分 hsiang fên) of Citta and the Caitasikas. By uniformity of cognized objects, therefore, is meant the fact that these ejects must be uniform.

(d) Uniformity as regards essence. The nature or the essence of Citta and its Caitasikas must be uniform. 
In the preceding four categories, the word Uniformity means "identity" as regards the first two classes, and "accord" or "close resemblance" as regards the last two. The Yogācärins insist that the functions of Citta differ very considerably from the functions of the Caitasikas, and that, consequently, they do not add to their list uniformity of functions such as is postulated by the Sarvāstivādins.

B. The Internal Relation between the Groups of Caitasikas. The Yogācārins add a further classification of the six classes of Caitasikas, according to their universality or particularity. The word " Universal" is used in four senses :-

(1) Universality as regards nature. The word nature (性 hsing) here applies to the four categories of Buddhismmeritorious, unobstructing neutral, obstructing neutral, and demeritorious.

(2) The Universality as regards sphere or place of activity. Here the word sphere, place, or stage, applies either to the division of the universe into Kāma, Rūpa, and Arūpa dhātus, or else to the still more detailed division of the universe into the nine abodes of sentient beings (mentioned under cosmic synthesis).

(3) Universality as regards time, meaning those Caitasikas which never cease their activity.

(4) Universality as regards co-existence. This applies to those Caitasikas which necessarily come into existence together, the arising of the one necessarily implying the arising of the other members of the same category.

Reviewing the six classes of the Caitasikas with a view to seeing how far each category conforms to each type of universality, the following facts come to light :-

1. The general or universal mental properties. These alone conform to all four types of causality. It is for this reason that they receive their name.

2. The particular mental properties. These are possessed of universality as regards nature and as regards sphere, but not the other two. 
3. The meritorious mental properties. These are possessed of universality only as regards sphere, being found in all three dhātus.

4 and 5. Mūla and Upakleśas. These are possessed of none of the four types of universality, but will be discussed at length below.

6. The indeterminate mental properties. These are possessed of universality as regards nature, inasmuch as they may be associated with either good or bad, but not the other three types of universality.

Or, to put the matter graphically, we get the following chart :-

The 4 types.

1. Nature

2. Sphere

3. Time

4. Co-existence

The 6 classes.

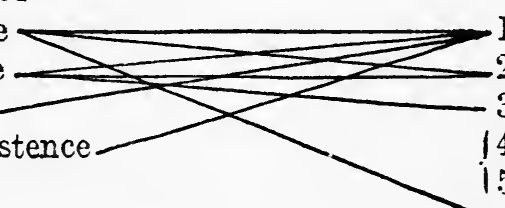

1. General

2. Particular

3. Meritorious

14. Mūla Kleśa

15. Upakleśa

6. Indeterminate

C. The Internal Relation between the Mūla and the Upakleśa dharmas. The various types of demeritorious Caitasikas, which received but scant attention in the preceding classification, are classified in various ways among themselves. The six Mūla kleśas have all a real and independent existence, and therefore receive no further classification, but the subsidiary or Upakleśas are classified in two ways :-

(a) Those kleśas which have a real existence, and those which possess only a conceptual or relative existence. The former are derived from the mūla kleśas, but have an independent existence. The latter are mere phases of the mūla kleśas which the mind singles out and names for pragmatic purposes. Of the twenty Upakleśas, seven belong to the former category and thirteen to the latter category. The absolutely existent are : (1) Ahrīkatā ; (2) Anapatrapā ; 
(3) Auddhatya ; (4) Styāna ; (5) Aśraddhā ; (6) Kausidya ;

(7) Vikșepa. The relatively existent are the remaining thirteen.

(b) Those which are greater, those which are intermediate, and those which are lesser. These three terms do not mean those which are greater or lesser as regards quality, but have reference merely to the number of states in which they are to be found. The great Caitasikas are to be found in all mental groups which are defiled, whether classed as obstructing neutral or positively demeritorious. This group consists of : (1) Auddhatya ; (2) Styāna ; (3) Aśraddhā ; (4) Kausīdya ; (5) Vikṣepa ; (6) Pramāda ; (7) Muṣita-sṃrti ; (8) Asamprajñā. The intermediate Caitasikas consist of those which are found in those states of consciousness which are definitely evil. This group contains: (1) Ahrīkatā ; (2) Anapatrapā. Needless to say, the positively evil states of consciousness also include the Caitasikas enumerated in the last group.

The lesser Caitasikas consist of those which arise separately, i.e. those which arise one by one in conjunction either with the intermediate or greater defiled Caitasikas, as has been explained when dealing with the Sarvāstivādin in groups above. The lower Caitasikas are, according to the Yogācārins : (1) Krodha; (2) Upanāha; (3) Mrakșa ; (4) Pradāsa ; (5) İrṣyā ; (6) Matsarya ; (7) S̃āṭhya ; (8) Māyā ; (9) Vihimsāa ; (10) Mada.

D. Classification of the Caitasikas according to the eight vijñānas. Whereas every Caitasika must be associated with some aspect of mind, it is not necessary that each of them be associated or capable of association with every one of the vijñānas. In fact, each vijñāna has a fixed number of Caitasikas with which it may be associated. These are :-

1. The Eighth Vijñana.-This is associated only with the five universal Caitasikas, which are necessarily present in every type of consciousness. The Âlaya-vijñāna is not directly associated with any other Caitasikas, even though it holds the seeds of all the other mental properties and vijñannas. 
2. The Seventh Vijñāna.-Since this is principally concerned with distinguishing between the mine and the not mine, giving rise to the various attman heresies, all branches of the Yogācanrins agreed that in addition to the five universal Caitasikas, the seventh Vijñanna was also associated with the following four defiled Caitasikas: (1) Moha; (2) Lobha ; (3) Māna ; (4) Drșți. Apart from this, however, there was some difference of opinion. Some asserted that this Vijñāna was correlated with these nine and none other, but more contended that a certain number of other Caitasikas must be admitted. The principal theories on the subject may be summed up in the accompanying chart.

3. The first six Vijñānas.-Mano-vijñāna or the sixth Vijñāna is associated with all of the fifty-one Caitasikas, while the first five being more passive agents for the reception of impression are associated with only thirty-four of the Caitasikas, as may be seen from the accompanying chart.

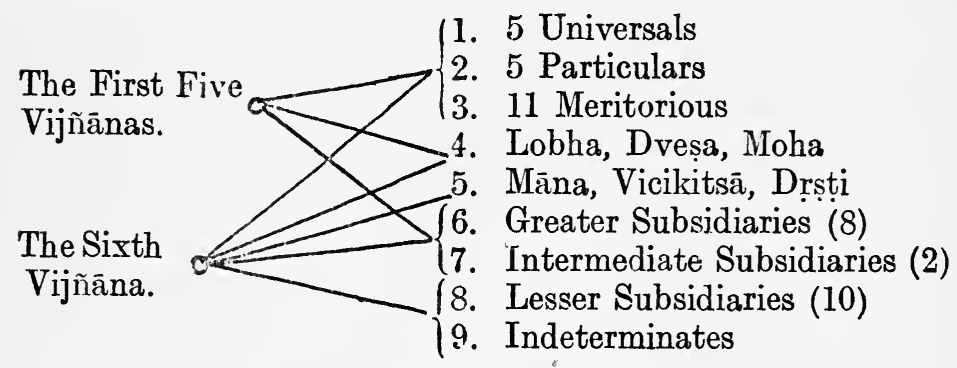

We have already had a somewhat detailed account of the treatment of the Caitasikas by the Sarvāstivādins and Yogācārins. Had the limitations of space permitted we should now have examined the treatment of the subject by the Sthaviravādins. The Sthaviravādins, however, were chiefly concerned with showing the co-ordination that exists between the fifty-two Caitasikas and their eighty-nine divisions of conscionsness, not a very interesting subject, and as these details are already accessible in English (Compendium of 
Philosophy, parts ii and iii, also Expositor), we may give ourselves the pleasure of allowing these matters to go untouched.

\section{The Citta-viprayukta Dharmas ${ }^{1}$}

Finally we have to examine the miscellaneous dharmas separate both from matter and mind, and which as a separate category were completely ignored by the Sthaviravādins; in fact, the enumeration of these dharmas as really existing entities is an essential feature only of the Sarvāstivādin school, with its curious half Platonic, half realistic philosophy. This category was the principal point of attack by rival systems, such as the Sautrāntikas.

Even the Yogäcārins, who were closely affiliated historically with the Sarvāstivādins, and who nominally accepted the fourteen Citta-viprayukta dharmas of the Sarvāstivādins together with an additional ten of their own, were really in accord with the Sautrāntikas, since they taught that the Viprayukta dharmas are not really separate and independently existing entities, but are merely modes of nāma-rūpa which the mind singles out and gives a separate name.

This half-hearted acceptance of the Viprayukta dharmas was entirely repugnant to the Sarvāstivādins, who believed that attainment (prāpti) words (nāmakāya), or uniformity of characteristics (sabhāgatā), were quite as real entities as the four mahābhūtas, or consciousness. From the point of view of the history of human thought, it would be of interest to deal at length with the long arguments for and against the separate or integral interest carried on by the Sarvästivādins and Sautrāntikas, as recorded in the Abhidharma Kośa (4, latter half), but the scope of our present work renders this out of the question, and we reluctantly confine ourselves to a bare enumeration of the lists, hoping at some future time to handle the matter at length.

1 For Sarv. A.K. 4-13b ff. For Yog. 2-5b; A.V.P. 1-4a. 


\section{(a) The Sarvästivādin List}

1. Prāpti, or attainment.

2. Aprāpti, or non-attainment.

3. Sabhāgatā, or uniformity of characteristics.

4. Jivitendriya, or vitality.

5. Jäti, or birth.

6. Sthiti, or continuance.

7. Jarā, or decay.

8. Anityatā, or death.

9. Asaṃjñīka, or unconsciousness.

10. Asamjñì-samāpatti, or mental training leading to unconsciousness.

11. Nirodha-samāpatti, or the mental training leading to the cessation of all existence.

12. Nāmakāya, or words.

13. Padakāya, or sentences.

14. Vyañjanakāya, or letters.

\section{(c) The Yogācārin List}

The order of enumeration was somewhat different, but the Yogācārins retained all of the above fourteen Citta-viprayukta dharmas and added the following ten of their own :-

1. Pravrtti, phenomena as opposed to Nivrttti, noumena.

2. Evambhagiya, or individuality.

3. Pratyanubandha, or correlation.

4. Javanya, or change.

5. Anukrama, or succession.

6. Deśa, or space.

7. Kāla, or time.

8. Saṃkhyā, or number.

9. Sāmagrī, or inherence.

10. Bheda, non-inherence or separation. 


\section{PART III}

\section{COSHIC DYNAMICS}

\section{The Nature and Scope of Causality}

\section{Emphasis on Causality.}

One of the most important factors in Buddhist philosophy is its insistence upon the theory of causality or causal origination. It is repeatedly discussed in the sutras, frequently with especial reference to other opposing views of life. In this connexion a passage from the Anguttara Nikāya may be of interest.

"There are, 0 monks, three views held by the heretics which, when followed by the learned, are calculated to land them in moral irresponsibility in spite of the perfection which they have attained. What are these three views? Some Sramanas and Brahmins there are who maintain that whatever a man has in this life of pleasure or of pain or neither is purely due to predestination; others say it is due to the will of God; others that it is due to blind chance.

"Now, $\mathrm{O}$ monks, when I find Sramanas and Brahmins holding or preaching such views I enquire of them whether they really believe in them. And when they answer in the affirmative, I say to them: 'Now, so then you must acknowledge that men become murderers, thieves, adulterers, liars, etc., on account of fate, God's will, or blind chance. Accordingly, all attempts at improvement or distinction between right and wrong become of no avail. Such being the case, the moral regeneration of the fallen becomes impossible.' This sort of reasoning must silence those who hold any of the three views mentioned above."

The reasoning of the Buddha may be somewhat too pragmatic to please the purely logical, but it serves to bring out quite clearly the theory that things have their origin in cause and effect, and that so far as our own destiny is 
concerned, we are responsible for the effects, inasmuch as we are responsible for their cause.

\section{Terms for Cause.}

The doctrine of causation then was, in the first place, associated with the doctrine of moral responsibility, but the doctrine was also connected with the two Buddhist marks of Impermanence and Anattman. Nothing is permanent or selfexistent. All things in the universe are the ephemeral products of various causes and conditions. ${ }^{1}$

But while all branches of Buaddhism are in agreement as to the validity of the causal law, on probably no point is there as much divergence as regards the interpretation of details. In the Nikāyas we find only such phrases as "Because of the existence of this, that exists ; this arising that also arises." Nor is there any specific word which covers all forms of the causal law. We find only such words as ko hetu, ko paccaya, "for this hetu (or cause), for this paccaya (or conditioning relationship)."

These two words were destined to have a curious history. ${ }^{2}$ In Sthaviravādin Buddhism hetu came to have a very narrow significance, namely, to indicate the conditionment of certain states of consciousness by the three poisons, greed, hate, and ignorance. Hence those states of consciousness which are affected by these are called sahetuka, or possessed of hetu or cause. Paccaya, on the other hand, came to signify any form of causal relationship, or the various ways in which one thing could stand in relation to another. In fact, the last book of the Pali Abhidharma is concerned almost exclusively with the twenty-four paccayas or possible relationships between different phenomena.

In the North, on the other hand, both by the Sarvāstivādins and the Yogācārins, ${ }^{3}$ the two terms were used

1 Tika Nipāta, 61. P.T.S. ed., vol. i, p. 173.

2 Passages to this effect are too numerous to mention. Cf., however, especially Pratītya-samutpāda Śāstra (十二因緣 論).

${ }^{3}$ List of authorities will be found in section 3 below. 
in a very different way. Here hetu means cause proper, or direct or primary cause, while pratyaya signifies general affecting conditions. In any particular causal nexus pratyaya means not the cause proper (which is hetu), but the additional circumstances under which a specified cause acted. Hetu then is primary cause, pratyaya is secondary cause, and the two together bring about phala or effect. Thus, for example, a seed is planted in the ground; through the influence of the earth, sun, rain, etc., it grows and becomes a tree. The seed is hetu ; earth, sun, and rain, are pratyaya; and the tree is the phala. Thus in contradistinction to the twenty-four paccayas of the South, we find in the North a list of six hetus, four pratyayas, and five phalas.

With all branches of Buddhism the doctrine of causation is closely associated with the theory of Karma. Literally, karma means action or deed, and that is still its most important significance. Later, it came to have the added meaning of result of action-the reward of the good and the punishment of the bad. It is in this sense we frequently meet the expression " he has good (or bad) karma awaiting him". Finally, it came to mean the whole law of causation when it has reference merely to moral retribution.

In the early days, and in Sthaviravādin Buddhism, general causality and karma were very sharply distinguished. Karma was one of the many kinds of causes that may bring about a certain result. Thus, Nāgasena explains to Milinda (M.P. I, 191, R. D.Ktr.) that though suffering may be caused by karma, yet it may also be due to other causes. Even the Buddha, free from all evil, suffered pain and illness, was injured by a stone, etc., not because of past misdeeds, but because of various external causes.

"Suppose, O king, a clod of earth were to be thrown up in the air, and to fall again on the ground. Would it be in consequence of any act that it had previously done that it would fall ?"

"No, sir. There is no reason in the broad earth by which 
it could experience the result of either good or evil. It would be by reason of present cause, independent of karma, that the clod would fall again."

"Well, O king, the Buddha should be regarded as the broad earth. As the clod would fall upon it irrespective of any act done by it, so also was it irrespective of any act done by him that the splinter of rock fell upon his foot."

In like manner (cf. Phil. 149), though karma may cause the death of a man, the death may be due to one of several reasons. Milinda cites external causes and karma, while the Compendium of Philosophy gives (1) expiration of the span of life; (2) expiration of karma; (3) expiration of both ; (4) destructive karma.

It should be noted, however, there was a constant tendency to increase the scope of karma. Thus, in the Katha Vatthu, one of the seven Abhidharma works of the Sthaviravādins, it is distinctly denied that matter can be due to karmaic causality, while in the Abhidhammattha Sangaha, the four things which are said to be the origins of material phenomena are: (1) karma ; (2) mind; (3) physical change ; and (4) food (p. 161). In the Sarvāstivādin works it is repeatedly said that the cause of the recreation of the universe is the aggregate effect of the karma of sentient beings in the past, while in the later Mahāyanna schools, where the basis of the whole universe is said to be mind, the appearance of the whole universe is due to karma and its correlates.

\section{Universality of Causal Law.}

Buddhists believe that their doctrine of cause and condition is universal as regards : (1) place ; (2) time ; and (3) object.

(1) Causal law applies uniformly to all portions of the universe, both in the innumerable material worlds and also in the various heavens and hells.

(2) Causal law applies to the three periods of time, past, present, and future. To a Buddhist this means, moreover, that the circle of causality is endless, that there was never 
a beginning, and that there will never be an end. Hence they reject the belief in a first or ultimate cause. Vasubandhu has a long and very interesting passage in the Abhidharma Kośa defining the Buddhist position on this point (A.K. 7-6a).

(3) It applies to all objects. The only exceptions are the Asamskrta dharmas, which are eternal and uncaused. All of the Samskrta dharmas, however, whether Rūpa, Citta, Caitasika, or Citta-viprayukta, have only a dependent or conditioned existence, and are without any substantial existence of their own. Buddhism distinguished itself from most other systems by applying the doctrine of causality and non-substantiality to the mind as well as to the body.

We are told, moreover, that even the Buddhas are subject to causality:-

"Even the Buddhas of the three ages (past, present, and future) have not been and shall not be able to alter this great law." 1

This is a very important point, inasmuch as it is a doctrine which distinguishes Buddhism from practically every other religion. In most other systems of thought, though the causal relationship is in some way recognized, the higher powers, especially the Supreme Being, are considered superior to this law, and are able, as shown by their miracles, temporarily to abrogate it. Buddhism, though accepting the possibility of miracles, seeks to correlate them with causality. The favourite theory of the higher law is introduced. Just as physical scientists by increased knowledge are able to bring about results which to an'ordinary man seem marvellous, so, according to Buddhism, do sages by means of past karma gain certain powers which enable them to control the elements. To the Buddhist, increase in the power of vision by means of the telescope is neither more nor less miraculous than increase of vision (clairvoyance) by means of the cultivation of the psychic faculties. Even in Mahāyāna,

1 From S. Kuroda's small pamphlet, " Outlines of Mahāyāna Buddhism "section on Causality. 
where the Buddhas accomplish the salvation of sentient beings, this salvation must be effected through causal agencies.

One final point deserves attention-all schools of Buddhism agree that nothing can be produced by the action of a single cause, that every dharma is the product of at least two causes. In the first instance this doctrine was probably directed against the doctrine of Íśvara or the creating deity, but in later times it came to imply that to produce an effect a cause requires adventitious aid from without. It is not, therefore, true to say that every cause necessarily has an effect, because some single causes, finding no favourable conditions, never come to fruition. It is possible, moreover, for a strong cause to render a weak cause barren.

Applications of Causal Law.

The Buddhists applied their theory of causality in two ways. The first was from the point of view of the groups of dharmas taken as a whole, more particularly the personality, human or otherwise. The second was from the point of view of each of the dharmas taken separately. The first, therefore, we may call synthetic, the second analytical. ${ }^{1}$

The first aspect was prominent even in the early period of Buddhist philosophy, and was merely the development of the theory of karma, showing how, for certain causal reasons, a man would be reborn at death in one of the heavens or hells. The later schools did little more than systematize or formularize the older doctrines. This aspect of causality was largely centred around the old rune, known as the Pratityasamutpäda.

The second aspect only became prominent in the Abhidharma period. Here an attempt was made to distinguish and define the fundamental types of causes, and show how the various kinds of personalities and all other combinations come into being by the action of these types of causes upon the various single dharmas.

1 For further discussion of these two points of view, see Wei Shih, pp. 212 and 217. 
Each one of these aspects is of great importance in the history of Buddhist philosophy, and deserves a special section to itself.

\section{The Law of Causality applied to the Individual}

The Chain of Causation.

We have seen the personality to be a constantly changing compound formed and fashioned under the influence of Karma. The question now arises, what is the exact way in which the personality is evolved and disintegrated? The Buddhist answer to this question is to be found in the Pratityasamutpāda or twelve-fold chain of causation. In all variations of Buddhism it is seldom that sermons lack mention of the time-honoured rune. In spite of its popularity, it seems difficult to ascribe to it logical exactitude, though the uses which have been made of it are innumerable. It is at one and the same time an abstract table of the sequence of cause and effect, and a list of the concrete stages in the supposed history of the origin, maintenance, disintegration, and persistence or transmigration of the individual ego, while in Mahāyāna it is used to explain the whole process of development of the objective world, including the factors of existence or dharmas from the universal essence of mind. ${ }^{1}$

In the Visuddhi Magga we are shown how the good Buddhist is not content with accepting life at its face value, but attempts to solve the problem of origination: "The monk who is desirous of knowledge enters on a search for the causes of the dependence of name and form, just as the skilful physician seeing a disease will search to find how it arose. At first he reflects as follows: 'Name and Form cannot be without a cause as they are the same everywhere, at all times, and for all people.' Having made this reflection, he begins to investigate the causes and dependences of Form, as follows: 'When this body comes into existence it does not arise in the midst of lotuses-nor of jewels-(etc.), but ill-smelling,

1 Cf. e.g. part iii of 起 信 論 (= Mahāyāna Śraddhotpāda Śāstra). 
disgusting, and repulsive, it arises between the stomach and the lower intestines . . . As it comes into being, these fourignorance, desire, attachment, and action-are the cause of it, inasmuch as they produce it. Food is the dependence, inasmuch as it supports it. These five are its causes and dependences ....'1

"Having thus grasped the dependence of form, he then grasps the dependence of Name, as follows: 'In dependence upon the eye, and with respect to form, arises Visual Consciousness (and so on, through the other six phases of consciousness).' When he has thus perceived the dependent manner of the existence of Name and Form, he reaches the insight: 'As Name and Form have at the present a dependent manner of existence, so also had they in past time, so will they have in the future." (Warren, Bud. in Trans.)

By a similarly continued process of psychological analysis we find in the end the conclusion reached that Name and Form in its origin and dissolution is a part of a universal chain of causation. This process is recorded in a sutra of the Northern tradition, the Sütra on Cause and Effect in the Past and the Present (No. 666), which is really a life of the Buddha. The passage in question runs as follows :-

"At this time, the third night of his meditation, the Bodhisattva examined the nature of sentient beings and for what reason old age and death exist. Then be saw that old age and death have birth for their origin, for apart from birth there is no old age and death. Again, this birth does not arise because of God, or of itself, or without cause, but arises because of causes and conditions, for it is derived from existence or deed-process in the Kāma dhätu, the Rūpa dhätu, or the Arūpa dhätu. Then he examined this three-fold deedprocess and how it arose, and saw that it was derived from fourfold Attachment? Then he examined this four-fold Attachment and how it arose, and saw that it was derived from Desire. Then he examined this Desire and how it arose, and saw that

1 Quoted from Warren's Bud. in Trans. 
it was derived from Feeling. Then he examined this Feeling and how it arose, and saw that it was derived from Sensation. Then he examined this Sensation and how it arose, and saw that it was derived from the Six Sense Organs. And whence came these Six Sense Organs? He saw they are derived from the Material and Mental aspects of the personality (Name and Form). Then he examined Name and Form and how it arose, and saw that it was derived from Consciousness. Then he examined Consciousness and how it arose, and saw that it was derived from Action. Then he examined Action and how it arose, and saw that it was derived from Ignorance ... . Moreover, if Ignorance be annihilated, then is Action annihilated. If Action be annihilated, then is Consciousness annihilated. If Consciousness be annihilated, then is Name and Form annihilated. If Name and Form be annihilated, then are the Six Sense Organs annihilated. If the Six Sense Organs be annihilated, then is Sensation annihilated. If Sensation be annihilated, then is Feeling annihilated. If Feeling be annihilated, then is Desire annihilated. If Desire be annihilated, then is Attachment annihilated. If Attachment be annihilated then is Deedprocess annihilated. If Deed-process be annihilated, then is birth annihilated. Finally, if Birth be annihilated, then are Old Age, Death, Anguish, Suffering, Mental Affliction annihilated." 1

To enumerate them in their proper order, the twelve Nidānas are :-

1. Ignorance, Avidyā.

2. Action, Samskāra or Karma.

3. Consciousness, Vijñāna.

4. Name and Form of Mind and Body, Nāma-rūpa.

1 Fasc. 3. The enumeration and partial explanation of the twelve Nidãnas is to be found in many other portions of the canon, especially the Sūtra Pitaka (see sūtra 15 of D.N. and R. Davids' introduction to his trans. of this sūtra, D.B.2,p.4). The Chinese counterpart of this sūtra is D.A.,p.48b(Kyōto ed.), where, however, all twelve instead of only ten links are given. 
5. The Six Sense Organs, Șaḍāyatana.

6. Sensation, Sparśa.

7. Feeling, Vedanā.

8. Desire, Truṣạā.

9. Attachment, Upādāna.

10. Deed-process or activity existence, Bhava.

11. Birth, Jāti.

12. Old Age, Disease, and Death, Jarā-maraṇa.

\section{(a) Hīnayāna Interpretation}

It must be confessed that this ancient rune of the Buddhists lacks logical precision, and later minds were much concerned with the correct interpretation. Among all the branches of Hinayāna there is remarkable agreement. The law of transmigration is brought in, and the first two links are made to refer to the past life, the next eight links to the present life, and the last two links to the future life. ${ }^{1}$ Or more in detail the causal sequence is as follows:-

\section{Past}

1. Ignorance, the position in the past when man had passions through the operation of ignorance or delusions.

2. Action.-The position in the past existence, where, as the result of evil passions, good or bad karma was made.

\section{Present}

3. Consciousness.-The position in this existence where a man enters his mother's womb, and first receives consciousness-in other words the moment of conception.

1 Abhidh. explanations of the Prat. Sam. are too numerous to mention. As regards Hĩn., however, for Sth. see append. to Sīläcāra's "Word of Buddha", excerpts from Visuddhi Magga in Warren's " B. in Trans.", chap. 2 ; R.P. 189 and 259 . For Sarv. A.K., latter half of f. 9 and all of f. 10 ; N.A. 25 ; P.A. 14 ; M.V. f. 3 and f. 25 . All these are in essential agreement, so it is unnecessary to cite additional authority for statements on Hīn. interpretations given hereafter. 
4. Name and Form.-The position where the five or six sense-organs are formed in the mother's womb. Name is here an inferior stage of mental operation which belongs to the fœetus in an incomplete state of corporal formation, or Name and Form together mean the mental and physical state of an embryo which has passed about four weeks in the maternal womb after conception. We have already seen the five stages of the fotus to be (1) Kalala, (2) Arbuda, (3) Pesi, (4) Ghana, and (5) Prasakha. The embryo at the stage of Name and Form is said to have passed through the first four stages named above, and also through a part of the fifth.

5. The Six Organis of Sense.-The position where a man comes out of his mother's womb, and his organs are perfectly formed, but has not yet begun to use them.

6. Sensation. ${ }^{1-T h e}$ position in infancy where a man comes into contact with the external world. This is the stage of a child during the first two or three years after his birth, during which his consciousness is dim, and it does not notice the subjective world.

7. Feeling.-The position of a child where after five or six years of life he begins to become acquainted with subjective pains and pleasures. Till its tenth year the child's mental and bodily functions develop without its feeling the more sensual desires of the flesh.

8. Desire or Craving.-The position of a man where after fifteen or sixteen years of life he begins to come under the control of the passions and desires. He now begins to covet objects of comfort but without striving strenuously to attain them-to experience the desires

1 A little confusion may be caused by the fact that the older trans. of Sparśa was contact, sensation being used for Vedanā. The above trans., however, is considered more accurate; cf. part ii, discussion of Vedanā skandha. 
of the flesh, but has not as yet a strong intention of fulfilling them.

9. Attachment or Clinging.-The position where a man reaches the age of 20 or 30 years of age, with passions and desires growing stronger and he is no longer able to curb them, as they now possess a lasting quality. This is really nothing more than an intensified form of desire.

10. Existence or Deed-process.-The position where a man performs various actions under the influence of his desires, and good or bad karma for his next existence is thereby engendered. It is produced by attachment and corresponds in the last existence to action, which gives rise to the present existence. Existence here means being plus action, or originating existence or karma existence.

\section{Future}

11. Birth.--The position of a man in the next existence, where he once more enters his mother's womb and thereby reappears in the world of sentiency to experience good and bad karma.

12. Old Age and Death.-The position of the man in the future existence where he undergoes the ravages common to mortal flesh. Links No. 11 and 12 are the same as 3 to 10 inclusive.

Consequent upon this interpretation of the twelve Nidānas, the Buddhists have invented several supplementary methods of classification.

1. The three elements of Causal Law.-As regards sentient beings there are three ${ }^{1}$ invariable elements of causality. These are: (1) Delusion, or the passions ; (2) Action, or the carrying out of the delusions or passions into practice; (3) Suffering consequent upon evil action is the necessary suffering.

1 佛敎統 一 諭, v. 1, p. 163, collects and compares canonical passages on the subject. 
In the Pratitya-samutpäda (1) Ignorance on one hand, and Desire and Attachment on the other are considered identical from the causal point of view and together constituteDelusion. (2) Action and Existence or Deed-process are considered identical and together constitute Action in the three-fold division. (3) Consciousness, Name and Form, Sense Organs, Sensation, and Feeling, on one hand, and Birth, and Old Age, and Death are considered identical, and together constitute Suffering.

2. Cause and Effect in the Three Periods.-(1) Delusion, and (2) Action may be taken together to form Cause, while (3) Suffering constitutes the Effect, and as the chain of causation extends over the three periods-past, present, and futurethe twelve Nidānas may be divided ${ }^{1}$ as follows :-

(A) Cause and Effect in Past and Present

(a) Past Cause

1. Ignorance.

2. Action.

(b) Present Effect

3. Consciousness.

4. Name and Form.

5. Sense Organs.

6. Sensation.

7. Feeling.

(B) Cause and Effect in the Present and Future

(a) Present Cause

8. Desire.

9. Attachment.

10. Deed-process or Existence.

(b) Future Effect

11. Birth.

12. Old Age and Death.

1 佛敎統 一 論, vol. i, p. 160. 
3. Commentarial Modifications.-In this connexion two matters require notice. First, in the immediately preceding table, in the past there is only cause and no effect, and in the future there is only effect and no cause. But the commentators state very emphatically that this is only because the table was given only in order to explain the present existence, and that unquestionably for there to have been cause in the past there must have been effect; and that as the result of effect in the future there will (unless Nirvāna be gained) be a cause. Secondly, although different words are used for the same causes and effects in the different periods, yet that in reality the different terms are interchangeable. Consequently, the commentators ${ }^{1}$ draw up the following amended and amplified chart:-

\section{Past}

1. Effect.-(1) Birth and Old Age and Death or its equivalent; (2) Consciousness, Name and Form, Sense Organs, Contact, Sensation.

2. Cause.-(1) Ignorance and Action or its equivalent; (2) Desire, Attachment, and Deed-process.

\section{Present}

1. Effect.-(1) Consciousness, Name and Form, Sense Organs, Sensation, Feeling, or its equivalent;

Birth, Old Age, and Death.

2. Cause.-(1) Desire, Attachment, Deed-process or its equivalent; (2) Ignorance, Action, etc.

Future

1. Effect.-(1) Birth, Old Age and Death or its equivalent; (2) Consciousness, Name and Form, Sense Organs, Sensation, Feeling.

2. Cause.-(1) Ignorance, Action or its equivalent;

Desire, Attachment, and Deed-process.

${ }^{1}$ Cf. arrangement in 佛教統 一 諭, vol. i, p. 162. 


\section{(b) Mahāyāna Interpretation ${ }^{1}$}

The interpretation of the chain of causality in the Sarvāstivādin and Sthaviravādin schools is in such close agreement on all essential points that it has been possible to consider them together. Here, however, the Yogãcārin school introduced radical innovations. The most important points were as follows :-

1. A two-fold instead of a three-fold relationship. In Hinnayāna the chain takes account of three lives-past, present, and future. In Mahāyāna it shows the causal relationship of two lives only, the first ten belonging to one life, and the last two to the other life. It may be applied, however, either to the relationship between past and present, or between present and future. Thus, the present life may be considered as links 11 and 12, results of 1-10 in the past life; or as links 1-10, resulting in 11 and 12 in the future life. Thus, 11 and 12 cover the same time, place, person, and stage as the whole of 1 to 10 , being merely two different ways of regarding the same group of dharmas, the one as cause, the other as effect. The Yogācārins assert that the causal aspect has received greater emphasis and subdivision than the resultant aspect merely in order that, by knowing the exact nature of the causal process, we may control the nature of our next re-birth, or, better still, so curb the causal factors that no further re-birth takes place.

2. The four-fold classification of the nidānas. The Hinayãna classification of the nidānas into (1) past cause, (2) present effect, (3) present cause, (4) future effect is, therefore, completely superseded, and in its place we find an entirely different four-fold grouping of the twelve links, largely based on the idea that the phenomenal world around us is but the expression, manifestation, unfolding (現 行, hsien

1 The Mădhyamikas denied the Prat. Sam. from the Absolute standpoint, but accepted the Sarv. interp. for their relative philosophy. Cf. Mad. Vr. (Chinese trans.), f. 26, etc. Consequently, what is known as the Mahāyāna interpretation began with the Yogācārins. For these see V.M.S., f. 8, p. 35 seq., and Wei Shih, p. 217, and Prat. Sam. Sāstra. 
hsing) of the seeds (mental, of course) which are stored up in the Âlaya-vijñana. For the phenomenal world to come into being, then (substantive matter having been denied), it is necessary (1) that some causal force bring about the formation of the seeds of each dharma; (2) but these seeds even after they have been created will remain quiescent in the Allayavijñāna without manifesting the phenomenal universe unless some new force comes as a stimulus or a fertilizing force. Thus, for one plant to produce another plant it must produce seed, and this seed must be subject to the fertilizing influence of ground, rain, and sun. With this in our minds, we can now understand the four-fold category of the Yogäcärins, wbich is :

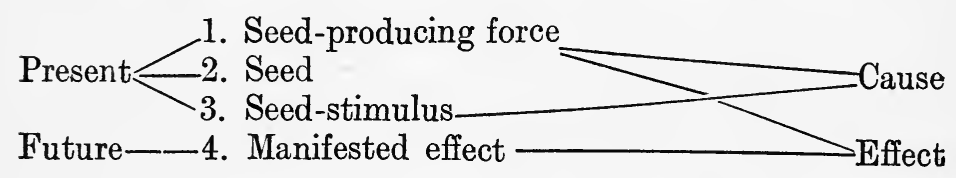

Into these four groups the twelve nidānas are placed in the following way :-

1. Seed-producing Force.-This consists of ignorance and action. These are the ultimate causes of re-birth, since they alone are powerful enough to produce seeds. Ignorance is divided into two kinds: (i) ignorance concerning cause and effect, i.e. lack of knowledge that demerit will be invariably punished and merit rewarded, if not in this life then in some other. Owing to this type of ignorance, men perform actions that will bring about re-birth in the lower gati ; (ii) ignorant evaluation, i.e. even though knowing the laws of cause and effect, men perform actions which will lead to re-birth in one of the heavens of the Kāma, Rūpa, or Arūpa worlds, not knowing that these spheres bring no permanent happiness.

Action is subdivided in several ways, but in the present instance only the division of action into unfortunate, fortunate, and immovable need be noticed. The first leads to re-birth in the lower gati ; the second to re-birth in the Käma heavens, and the third into the two higher worlds (Rūpa and Arūpa). 
2. The Seed.-This consists of the links Consciousness, Name and Form, the Sense Organs, Sensation and Feeling.

(a) Consciousness is the seed of the eighth vijñāna, which serves as the basis of existence in the future life in any of the divisions of the three worlds. This is the most important of the resultant seeds, since the eighth or Ālaya-vijñanna is the substratum of all the other dharmas.

(b) Name and Form.-These are the seeds of all the divisions of the skandhas of the future personality, excepting the seeds of (i) the Ālaya-vijñāna, (ii) the Six Sense Organs, (iii) Sensation, and (iv) Feeling. All these seeds belong to the field of the indeterminate Vipāka phala (see iii, p. 61).

(c) The Six Sense Organs.-These are the seeds which will give rise to the eye, ear, nose, tongue, body, and mental indriyas in the future existence.

(d) Sensation.-This is the seed which will give rise to the Caitasika Sparśa in the next life.

(e) Feeling.-This is the seed which will give rise to the single Caitasika Vedanā in the next life.

3. Seed-fertilizing Forces.-The seeds for the next life having been produced, have an innate tendency to sprout or germinate (future corporeal existence). As yet, however, the force which they can exert is too weak to act. The next two nidānas (Desire and Attachment), however, serve as a stimulant under whose influence the seeds awaken into full activity. Desire is more technically defined as the inferior, and Attachment as the superior kleśas associated with the Manovijñāna.

Bhava or Existence, the tenth nidāna, is defined by the Yogācārin school as being the above-mentioned seeds of the future life in their germinated stage, or when the process of sprouting has begun as the result of the influence of the kleśas.

4. Manifested Effect.-Just as the seed from an old seed lives on after the parent plant has decayed, bringing forth a new plant, so does the germinated seed from an old 
personality, after the death of the latter, result in the manifestation of a new personality. In this personality two stages are noticeable. The first is the waxing stage, from the moment the germinated seed enters the mother's womb to the time when, in middle life, the period of growth is over. This is called Jāti, birth, or the eleventh nidāna. From the time when growth ceases and decay sets in until the end of the new life the personality is said to be dominated by Jarā-maraṇa, or old age, disease, and death.

\section{Additional Remarks on Karma}

The Pratitya-samutpäda, and the whole process of causality as applied to the personality, are summed up in the word Karma. It was, therefore, to be expected that the Buddhist philosophers should have given a great deal of attention to this term, and for the Orientals to notice means to introduce subdivisions. It is impossible to go into detail concerning all these minor classifications, more particularly as most of them are only of ethical import and have no relation to philosophy, but one or two general terms may ke mentioned.

The Sarvāstivādin and Yogācārin divisions of karma are chiefly concerned with matters dealing with the proper enumerations of the Silas or moral precepts, though a good deal of space is devoted to the division of karma into Vijñapti and Avijñapti, corresponding to the classification of Rūpa into Vijñapti and Avijñapti which we have given above. This point, however, we are compelled to ignore. For the rest there is little system in the treatment of karma, though a casual survey of the Abhidharma Kośa (4th Kośasthāna) gives us the following list of technical terms, some of which throw a good deal of light on the northern theory of the process of causal law in its application to the individual.

The most important terms are:-

(1) Drșta-dharma-vedanīya, or karma whose fruits will be experienced in the present life. 
(2) Upapadya-vedaniya, or karma the results of which will be experienced in the next existence or not at all.

(3) Apara-paryāya-vedanīya, or karma the results of which may be experienced in any future life.

(4) Niyata-vedaniya, or karma the results of which will be experienced at some particular and determined time, as opposed to :-

(5) Aniyata-vedaniya, or karma the results of which may be experienced at any time when favourable conditions allow.

(6) Karma-svaka, or autonomous karma or action, the result of which will be experienced purely by oneself, as opposed to :-

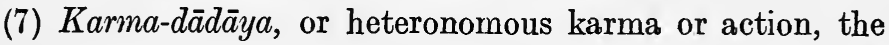
result of which will be experienced by others, as well as oneself.

(8) Karma-yoni, or karma the results of which are experienced by place of birth, such as in a wealthy family, a poor family, as a man, a deva, etc.

(9) Karma-pratisaranam, or karma the results of which will be experienced through environment in the future life. ${ }^{1}$

Among the Neo-Sthaviravādins, i.e. Buddhaghosa and his successors, more attention was paid to such matters, and we find with them the following elaborate chart of Karmaic relationships. ${ }^{2}$

There is first of all a division of karma with respect to time, secondly a division of karma with respect of function, and thirdly a division of karma with respect to priority of effect. Each of these groups has a four-fold division, making a total of twelve units of classification in all.

1. With respect to the first, we have the following subdivisions :-

(1) Immediately effective Karma: karma the fruit of which is to be experienced in this life. If its influence is counteracted,

1 Especially f. 13, 14, and 15 of Hsüan Tsang's trans.

${ }^{2}$ Cf. C.P., p. 143 seq., and the pamphlet reprint of an article in Bud. Review by S. Pereira, “Elucidation of Kamma” (year not stated). 
and it is unable to operate, it becomes non-effective. "A hunter shoots one arrow; if it misses the deer remains unaffected."

(2) Remotely effective Karma, or karma the fruit of which is to be experienced in the next life. Here, also, if through other causes this cause is unable to operate at that period, it becomes non-effective, i.e. is not carried over to another existence.

(3) Indefinitely effective Karma, or karma which is to be experienced in some after life. The scope of this karma is not so limited, and is liable to become effective at any time unless, in the meantime, Nirvāna be attained, whereupon, of course, it, too, becomes non-effective.

(4) Non-effective Karma (lit. karma which has been).This comprises all forms of karma of the first two classes which were too weak to operate, or were counteracted by some more powerful karma.

2. With respect to the second we have the following divisions :-

(1) Reproductive Karma.- "This causes conception and then is latent. It may or may not help further, according to whether it receives support or is counteracted. By conception here is meant only a resetting of the current of being (bhavanga) the fruit of a past karma of the remotely effective class of the Time classification" (P. Eluc. of Kamma, p. 8).

(2) Supportive Karma.-This renders assistance to reproductive karma, and the phenomena thereby brought into existence are given a permanent basis.

(3) Counteractive Karma.-This tends to render null and void the karma of the two preceding classes. It may thus counteract both good and bad karma.

(4) Destructive Karma.- This class, stronger than the last, cuts at the root of active or potential karma, and causes it to become inoperative.

3 . With respect to the third, we have the following subdivisions :- 
(1) Weighty Karma.-This is so called because karma of this nature operates all others. It may either be meritorious or demeritorious. In either case it may be productive, supportive, counteractive, or destructive. Demeritorious weighty karma precludes the operation of meritorious weighty karma till its results have been fully effected.

(2) Death-proximate Karma.-This is the Karma which determines the nature of the next birth. Should there be any weighty karma, meritorious or demeritorious, this, of course, would apply here. In its absence, however, whatever karma presents itself at the moment of death takes precedence over all else.

(3) Habitual Karma.- " This is the karma generated by constant repetition of thought, word, or act. It comes next in power to Death-proximate Karma, and, in fact, becomes Death-proximate Karma if it be forceful enough to overcome other karma."

(4) Cumulative Karma.-It comprises " all the accumulated karma, good, bad, and indifferent of the ages. It is, in fact, the whole of each being's illimitable past-the "chasing dogs ' of Indefinitely effective karma". If no new karma be powerful enough to act, then it is a karma of this class that will operate as Death-proximate karma. But cumulative karma is so great a store that there is absolutely no certainty (except to a perfectly enlightened one) as to bow it will act. It is compared to a fool's stone-throw. It may strike when least expected.

\section{The Law of Causality applied to the Elements of Existence}

We have examined the general scope of the Buddhist conception of the law of causation and its application to the human personality. We have now to undertake the somewhat more difficult task of considering some of the technical details involved in the theory, with especial reference to the cosmic

1 P.'s " Elucidation of Kamma". 
aspect. In the present instance, however, we are forced to distinguish between the development which the idea received in the Pali or Southern tradition on the one hand and in the Sanskrit-Chinese tradition on the other.

\section{(a) The Southern Tradition}

\section{Definition of Prasthāna and Pratyaya.}

The Pali worthies divide causality into Prasthāna (Pali, Pațthāna) and Pratyaya (Pali, Paccaya) relationships. Ledi Sadaw (Philosophy of Relations, J.P.T.S., 1915-16) has a very interesting definition of these two terms: "Patțhāna ${ }^{1}$ means (cause proper or) principal or pre-eminent cause among causes." "Paccaya may be defined as that event by which a fruit or effect derived from itself occurs," or general causation relationship in any form, and not necessarily the relation of direct cause to direct effect.

" Effects of (principal) causes are either direct or indirect. The one well defined sort of event which bears an indispensable relation to a given cause is said to be a direct effect. All other outcomes of this direct effect are indirect effects. Given the sole adequate cause, its direct effects invariably happen. But its indirect effects may, or may not, take place. There is no necessary connexion between a cause and these indirect effects. ... For example, greed (lobha) relates itself to its concomitant mental and co-existent physical properties by way of special condition (hetu). Here these properties directly spring into being along with their patthanas, or cause. That is, whenever greed occurs, they invariably occur. ... But the matter does not stop short there. Greed may give rise to a series of actions

1 Until the whole of the Patthäna has been editcd, it will be impossible for us to know the full implications of the various types of causes given by the Sthaviravädins, but I have thought it wise to give at least the names of the types of causes found in the Southern list in order that they might be compared with the Northern list, which I have attempted to explain some what more at length below. For further information see C.P., p. 191 seq., and J.P.T.S., 1915-16, p. 21 seq. Of less value is J. Wetta Simha's Singularity of Buddhism, p. $78 \mathrm{ff}$. 
in deed, word, or thought, even after its stimulus is withdrawn. These sequences, then, are mere outcomes or results of direct effects" (pp. 26 and 27).

Now, the difference between Patthāna and Paccaya "is that patțhāna is limited to non-transitive relations to its direct effects, whereas paccaya covers not only non-transitive relations to direct effects, but also transitive relations to indirect effects .. . Commentators paraphrase the word paccaya by upakaro, meaning rendering service. A mother renders service to her child by her function of conception, gestation, etc., and by her ministering to its wants. But when an adult filially minded son supports his mother in her old age he now becomes paccaya..." (pp. 27 and 28).

In the seventh book of the Pali Abhidharma, Pattthāna, twenty-four kinds of Paccaya are distinguished. These are as follows:-

1. Hetu, or root-condition.

- 2. Ārammana, or object.

3. Adhipati, or dominance.

4. Anantara, or contiguity.

5. Samanantara, or immediate contiguity.

6. Sahajāta, or co-existence.

7. Añ̃am-añ̃̃a, or reciprocity.

8. Nissaya, or dependence.

9. Upanissaya, or sufficing condition.

10. Purejāta, or antecedence.

11. Pacchājāta, or consequence.

12. Āsevana, or succession.

13. Kamma, or action (karma).

14. Vipāka, or effect.

15. Āhāra, or nutriment.

16. Indriya, or control.

17. Jhāna, or concentration.

18. Magga; or means.

19. Sampayutta, or association.

20. Vippayutta, or disassociation. 
21. Atthi, or presence.

22. Natthi, or absence.

23. Vigata, or abeyance.

24. Avigata, or continuance.

Application of the Twenty-four Pratyayas.

We are told ${ }^{1}$ that there are four different kinds of relations, namely, the relation of

1. Mind to mind.

2. Mind to body.

3. Body to body.

4. Body to mind.

(1) All forms of consciousness which we have previously grouped under thirty-three classes are related to one another under this category. "Here the relation is symmetrical; that is, the relation between the two terms $A$ and $B$ holds good as between $B$ and $A$." (2) The relation between resultant forms of consciousness and resultant forms of matter are included under this category. At the moment of conception they come into being simultaneously, but thereafter forms of consciousness arise in dependence upon external objects. (3) The relation between the four elements and their derivatives are included under this category. "It must be remembered that the derivatives cannot attain the status of a cause or paccaya. That is, the relation between the primaries $A$ and the secondaries $B$ is symmetrical. In other words, the relation of $A$ to $B$ cannot be reciprocally borne by $B$ to $A$." (4) Under this category may be instanced the correlation of the heart-basis to mind at the moment of conception.

The Abhidhammattha-sangaha adds to these four groups two others, viz. (1) relation between term and concept on one hand and mind on the other; (2) relation between one group of states of mind-and-body and another group of states of mind-and-body. There also the relation between the above

1 C.P., p. 193. 
six categories and the twenty-four pratyayas is stated to be as follows :-

(1) Mind to Mind:-

1. Contiguity.

2. Immediate Contiguity.

4. Abeyance.

3. Absence.

5. Succession.

6. Association.

(2) Mind to Mind-and-Body:-

1. Hetu.

4. Karma.

2. Jhäna.

5. Effect.

3. Means.

(3) Mind to Body:-

1. Consequence.

(4) Body to Mind :-

1. Antecedence.

(5) Term and Concept to Mind :-

1. Object.

2. Sufficing Condition.

(6) Mind-and-Body to Mind-and-Body :-
1. Dominance.
6. Control.
2. Co-existence.
7. Dissociation.
3. Reciprocity.
8. Presence.
4. Dependence.
9. Continuance.

5. Support.

(b) The Northern Tradition 1

Whereas the Sthaviravādin and Sarvāstivādin schools were in agreement on the personal interpretation of causality, as opposed to the Yogācārins, when we come to deal with the Northern interpretation of cosmic causality we find that here the Yogācārins and Sarvāstivādins are in agreement as opposed to the totally different account handed down by the Sthaviravādins. On certain points of detail the two northern

1 For Sarv. cf. especially A.K., the whole of ff. 6 and 7 ; N.A., f. 15 ; A.P. 14 ; M.V. 16-7b seq. For Yog. see especially V.M.S., f. 7, p. 32b, and Wei Shih, p. 212 seq. 
schools disagreed, but in the main the doctrines concerning this matter were in accord, and we may therefore treat them together.

Northern and southern traditions concerning cosmic causality seemed to have developed quite independently. Instead of a rather unco-ordinated list of twenty-four relations, we find four main pratyayas or ways in which one thing can stand in relation to another, while causality proper is explained by six or ten hetu and their five phala or effects. It is very interesting to note that this doctrine of the six or ten hetu and the five phalas are admittedly later developments of the original Buddhist ideas, but it is claimed that the doctrine of the four pratyayas was taught in the earliest Hīnayāna sūtras themselves. ${ }^{1}$ Unfortunately, we are unable to verify this statement, and though reference is made to the Samyukta A gama, none of the existing versions of that work contain the passage in question. The light which this statement throws on the development of Abhidharma ideas is very important, more particularly as it is in such strong contrast to the Sthaviravādins, who claim that their twenty-four pratyayas are all part of the original dispensation. Let us now proceed to examine each of these categories somewhat more in detail.

\section{The Four Pratyayas}

Pratyaya is explained, as we have seen, as being the conditions which bring about any given phenomenon. Consequently, the pratyayas explain the various ways in which one thing can stand to another. All such relationships fall into one or other of the following types ${ }^{2}$ :-

1. Hetu pratyaya, or direct causal relationship.

2. Samanantara pratyaya, the relation of uniform and nonintermittent succession.

1 The Mādhyamikas seem to have taken into consideration only the four prat., cf. Mad. Vr. (Chinese trans.), f. l, but also cf. the amplifications of M. P. P. Śāstra, f. 32, p. $1 a$ seq.

${ }^{2}$ A.K. $7-1 a$; N.A. $8-17 b$; A.P. $10-10 a$; V.M.S., pp. $33 b$ and $34 a$. 
3. Alumbana pratyaya, the relation between the object and the subject of perception.

4. Adhipati pratyaya, explained as the indirect influence which one dharma can have over another.

It is said that these four groups can be reduced to two. The first group would consist of hetu pratyaya alone, constituting direct causality, while the second group would consist of the remaining three pratyayas, constituting indirect or auxiliary causality. In fact, Adhipati pratyaya includes all forms of indirect causality, so that Ālambana and Samanantara are but sub-groups, which, however, are of sufficient importance to warrant separate mention.

1. Hetu pratyaya.-This refers to the relationship between two dharmas, when one is the direct cause of another. In other words, when one dharma is said to be the absolute cause of another, even though this causal process implies the action of other indirect conditions, this dharma is said to act as Hetu pratyaya. In the early days no attempt seems to have been made to differentiate this type of causality, but the later scholastics drew up a list of six or ten hetus, all of which are but subdivisions of this type of pratyaya. We shall consider all of these more at length hereafter.

2. Samanantara pratyaya.-When one set of dharmas is uniformly and without interval succeeded by another, the preceding group is called the Samanantara pratyaya of the succeeding group. This has especial reference to the relation of two different moments of consciousness within the same personality. Any group of mental dharmas (i.e. Caitasikas) has the duration of only a single kśana, but at the moment when this group disintegrates a new one arises to take its place and to inherit its potential energies. In this way the preceding group conditions the activity of its successor, but, at the same time, it cannot be termed its cause, since the succeeding group owes its origin to action or to the kleśas. Hence the Hetu pratyaya of the new group is either Karma 
or the Anuśayas, and its Samanantara pratyaya is the immediately preceding group of mentals.

The life stream of consciousness is considered more uniform and inter-related than any other life stream. Thus, two different phases of the body are not supposed to be related by means of Samanantara pratyaya. The commentators explain this by saying that this relation implies uniformity and contiguity between the condition and the conditioned. The relation between two successive phases of Rūpa possesses neither of these two requisites, since the process of change is slower and two different processes of replacement may be going on at the same time within the body, as opposed to the unified disintegration and replacement on the part of the mind.

In the same way the Citta-viprayukta dharmas find no place as Samanantara pratyayas, since there is no fixed order to succession in their appearance in the universe. Even among the mentals, the last thought moment of an Arhat was considered inoperative since no new group of mental dharmas arises, phenomena producing action and passions having been exhausted. There being no hetu, the last group of mentals cannot be said to exercise a conditioning function (A.K. 7-2a).

3. Alambana pratyaya, or percipient condition.-This corresponds to what the Cartesians would call the occasional cause. Conditioned by various external objects, different types of consciousness arise. The Sarvāstivādins believed that the nature of the newly arising consciousness is conditioned by the external objects, but that the cause of the origination remains Karma and the passions. Hence, the action of the external objects is called A Alambana pratyaya. This group is much more inclusive than the preceding, inasmuch as all objects or all the dharmas of the universe can act as A Alambana pratyaya, inasmuch as all dharmas can act as objects of perception, Rūpa being the Ālambana pratyaya of the five sensuous aspects of consciousness, while all dharmas whatsoever can act as the Ālambana pratyaya or the Sixth or 
Mano-vijñāna. In this way, even the Asamskrta dharmas and the Samskrta dharmas of the past and future can function as Ālambana pratyaya.

It is further stated that all dharmas retain the name of Allambana pratyaya even at moments when they are not serving as objects of perception, since they are always potential conditions, just as firewood is always called fuel even when it is not for the moment burning (A.K. 7-4). ${ }^{1}$

4. Adhipati pratyaya.-When we examine the nature of things we see that everything exerts an indirect influence over everything else. The snow on the Himālayas affects the climate, and hence the food, clothes, and lives of all other parts of the world. The indirect influence which every dharma exerts on everything else is called Adhipati pratyaya. This shows how greatly the Northern interpretation of the pratyayas differs from that of the Sthaviravādins, for the latter have kept the literal sense of Adhipati as dominance, while the Northern scholastics state this condition receives its name merely because it is vast and universal, inasmuch as this pratyaya is possessed by every dharma in the universe. It is even more widespread than Alambana pratyaya, since a dharma exerts an Adhipati influence even when it is not directly perceived.

The scope of Adhipati has only two limitations : (1) a thing cannot be said to exercise a causal influence over itself ; (2) the Samskṛta dharmas can have no influence over the Asamskrtas since the latter are by definition unconditioned. (A.K. 7-5a.)

From their very definition also we can see that the four pratyayas are applied to the various categories of existence in the following way: All four types of condition bring about the arising of both Citta and Caitasikas. The only exception to this is the Citta and Caitasikas of the heaven of unconscious-

1 For the Yog. modifications of Ālam. Prat. principally from the ontological point of view, see the Ālam. Prat. Śāstra by Dignāga, mentioned in the Introduction. 
ness. In this instance, as there is no perception, objective phenomena cannot be said to function as Ālambana pratyaya.

Only two of the pratyayas apply to Rūpa and the Viprayukta dharmas. These are Hetu pratyaya and Adhipati pratyaya. Not being percipient agents, Ālambana pratyaya does not apply to them. The reason for their exclusion from the category of Samanantara pratyaya has already been explained.

\section{The Six Hetus}

Let us now turn our attention to the Hetus, or types of direct causality. The subdivision of Hetu being a later development of Buddhist philosophy, there was some difference of opinion as to the exact number of causal types to be enumerated. For the most part the Sarvāstivādins ${ }^{1}$ had six in their list. The Yogācārins sometimes accepted the six hetus of the Sarvāstivādins, ${ }^{2}$ but frequently made mention of another list of ten hetus, which, together with five other modes of relationship, made up their full list of fifteen causal bases. $^{3} \quad$ These special causal theories of the Yogācārins, however, were of very little importance. They played but little part in the Yogācārin philosophy, absolute or relative. Many of the foremost commentaries ignored them (e.g. Wei Shih Lun Chêng I). Consequently, in the present instance we may content ourselves with enumerating the list of six hetus which were common to both the Yogācārins and the Sarvāstivādins, and of which frequent mention was made.

In point of fact, this group is merely a new edition of the pratyaya classification of causes in which the three pratyaya which have an indirect conditioning effect upon phenomena are brought together and counted as one hetu, called Kāraṇa Hetu, while the one pratyaya which has a direct causal

1 Cf. the authorities cited above for the Sarv. school.

2 Lañkāvatāra expounds the six hetus from the Yog. standpoint, 3-10b of the $10 \mathrm{f}$. version, and $2-21 b$ of the $4 \mathrm{f}$. version.

3 Cf. especially V.M.S., f. S, p. 33b, for full list and explanation. 
influence over phenomena is divided into five groups. The relation between the Pratyaya and Hetu groups is to be seen from the following chart:-

Pratyaya.

Hetu.

1. Hetu
2. Samanantara
3. Ālambana
4. Adhipati

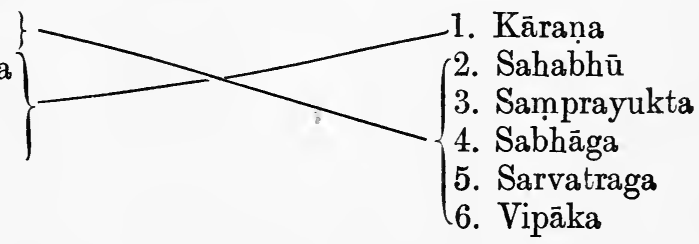

Let us examine each type of hetu individually :-

1. Kārana hetu. -This is causality in its broadest sense. It includes (1) all the other causes, and (2) all the dharmas. (1) Since Kāraṇa hetu is causality in general, all other causes are included in this category, being merely separate groups of kāranas. But for practical purposes it is advisable to distinguish types of causes which have special peculiarities, and to retain Kāraṇa as a term to apply to those causes which can receive no other classification, just as, to quote the Abhidharma Kośa (6-1a), ten of the ayatanas are called Rūpa ãyatanas, and yet one of them receives the specific title of Rūpa āyatana.

In this special sense Kāraṇa is distinguished from the other types of hetu by being both positive and negative. By the positive aspect is meant that the existence of any one thing exerts some kind of influence, even though slight, upon every other dharma. (See above, Adhipati pratyaya.) By the negative aspect is meant that when a certain dharma does not exert a specific influence upon another it can equally be termed a cause, as in this way the arising of the phenomenon in question is not impeded. When a king rules wisely and justly, this is a positive influence upon the welfare of the people. When the king fails to act at all the country goes to ruin, so that the very inaction or the absence of a thing exerts an influence upon other things. (A.K. 6-2a.) 


\section{MANUAL OF BUDDHIST PHILOSOPHY}

(2) It thereforefollows that every dharma is the Kāraṇa hetu of every other dharma, though it cannot exercise a causal influence over itself. Thus the element faithfulness (śraddhā) can be said to be the Kāraṇa hetu of faithlessness (aśraddhā). Through the inclusion of Ālambana pratyaya in this category, Nirvāna and the other Asamskṛta dharmas are likewise included in the list of Kāraṇa hetus. (A.K. 6-2b.)

2. Sahabhu hetu.-This is the term applied to explain the causal working of two dharmas which exist simultaneously. ${ }^{1}$ There are two different interpretations given to this type of hetu :-

(1) The firstis when several different dharmas all bring about a single effect at the same time. Thus the co-working of a number of men brings about the formation of a regiment. This implies a certain amount of co-ordination between the separate causal factors, which leads up to the second interpretation of this cause, which is the one favoured by the Abhidharma Kośa (6-2b), namely :-

(2) Sahabhū hetu is the simultaneous interaction of a certain number of dharmas. In certain cases co-existing dharmas not only bring about another separate effect, but they have a causal influence on one another. Here inter-relation implies symmetrical inter-relation, i.e. not only does $A$ act upon $B$ but $B$ acts equally upon $A$.

Instances of this are found in both material and mental phenomena. In any given molecule the inter-causal influence of the atoms of the four Mabābhūtas is called Sahabhū hetu. The relation of the Mahābhūtas, and the Bhautikas on the other hand, is not included in this class, as the relation is asymmetrical, the Mahābhūtas influencing the Bhautikas, while the Bhautikas cannot directly influence the Mahābhūtas.

1 The A.K. and A.P. differ in their interpretation of this type of cause. See A.K. 6-2b and A.P. 9-1 $a$; both views are found in M.V. 15-16a, etc. The A.P. follows the first and A.K. the second interpretation mentioned above. 
According to the Sarvāstivādins, a mental group contains fifty-four dharmas, which act as Sahabhū hetu. These are (a) Citta itself, (b) the ten universal or general Caitasikas, (c) the four Lakșanas of Citta, (d) the four Lakșanas of each of the ten Caitasikas, making forty in all. (A.K. 6-3b.)

3. Samprayukta hetu.-This is a further special class of Sahabhū hetu, and refers more particularly to the relation between Citta and the Caitasikas. This is distinguished from the preceding group by the closer nature of the union of the co-existing influencing parts. Consequently, every Samprayukta hetu is necessarily a Sahabhū hetu, but there are certain Sahabhū hetus which are not sufficiently interrelated to receive the name of Samprayukta hetu. The union of the latter is so close as to imply almost fusion, while the former means only conjoint action, in which each part retains its independent function. The Abhidharma Kośa illustrates the action of Sahabhū hetu as the travelling of merchants in a caravan in order to protect themselves from the dangers of the road, while the action of Samprayukta hetu is illustrated by these same travellers if they are performing exactly the same actions at exactly the same time. ${ }^{1}$

The Buddhists believed that this closer form of union could not be attained by the material dharmas or by the Cittaviprayukta dharmas, and it was therefore confined to the inter-relation of the various Caitasikas. Their function as Samprayukta dharmas depends upon their previously mentioned four- or five-fold uniformity.

4. Sabhäga hetu.-This is usually termed homogeneous cause. ${ }^{2}$ It is distinguished from the preceding category by not being contemporary with its effect; in fact, it must cease to exist before its phala can arise. It is likewise distinguished from Vipāka hetu, mentioned below, because the effects of

1 A.K. 6-10b.

2 There was a good deal of dispute over the correct interpretation of this type of hetu, particularly between the Sautrāntikas and Sarvāstivādins, the principal points of difference described A.K. 6-5a seq. 
Sabhāga hetu are of the same nature as the cause itself. Thus, when one apple produces another apple it is said to be a Sabhāga hetu. In the same manner the first stage of the human foetus is said to be the Sabhāga hetu of the later stages. Its nearest corollary, therefore, is the Samanantara pratyaya already discussed, but it is distinguished from this pratyaya in several ways. (1) It is a cause and not a condition, i.e. the nature of the mind as a whole is the conditioning factor of the succeeding moment of consciousness, while certain passions in the preceding moment of consciousness whose force brings about the arising of similar types of consciousness at a later moment is called a Sabhāga hetu. Samanantara pratyaya refers more particularly to the relation of two mental groups at two successive moments, while Sabhāga hetu may function over a prolonged period of time. (3) Consequently, Samanantara pratyaya refers only to the mind and mentals, while Sabhāga hetu can apply to the relations between any similar groups of dharmas, such as Rūpa, etc.

The Buddhist believed that everything had a tendency to reproduce itself. A good Caitasika of the present tends to produce a good Caitasika in the future; an evil Caitasika another evil Caitasika. This force or tendency may be checked or thwarted, or may be so weak that it is unable to reproduce itself without external aid, as in the case of indeterminate things. Where, however, the force is sufficiently strong to carry out its function of reproduction it is called Sabhāga hetu. Nevertheless, this causal force is very confined in its scope, because it applies to effects (1) only of the same nature, (2) the same section (部 $\mathrm{pu}$ ), and (3) of the same sphere.

The first applies to the three main categories, meritorious, demeritorious, and neutral. The sections consist of the various subdivisions of these three natures, such as the five groups. The third has reference to the various spheres of the universe. For this purpose the universe is divided into nine stages, one for the whole of the Kāma dhātu, one for each 
of the four groups of the Rūpa dhātu, and one for each of the Arūpa heavens. Thus a meritorious dharma may have sufficient force to reproduce itself in the Kāma world, but in order for it to lead to re-birth in the Rūpa dhātu it requires adventitious aid from without.

5. Sarvatraga hetu. ${ }^{1}-$ This is closely connected with the preceding type of cause, save that its scope is slightly broader. The dharmas which exert this influence are the Anuśayas root cr underlying passions, which give rise to later demeritorious types of consciousness. They receive the name Sarvatraga, or universally active, because each such root passion is the cause of the subsequent arising not only of its own type of demeritorious dharmas, but of all other passions of defilements, whether of its own section or not. In consequence of this definition, while Sarvatraga hetu, like Sabhāga hetu, is confined in its activity to dharmas of its own sphere, it is not, like the latter, confined to dharmas of its own section, and hence has to be enumerated as a separate type of cause.

6. Vipāka hetu. ${ }^{2}$-This is in some ways the most important of the hetus, for it is the essential link in the process of re-birth. Like the two preceding hetus, it is distinguished from Sahabhū and Samprayukta hetus because its effect can only come into being after the cause itself has expired, but it is distinguished from Sabhāga and Sarvatraga hetus because it is not limited in its scope to any section or sphere. The essential function of this type of causal influence is for evil hetu to bring about painful consequences, such as re-birth in one of the hells, and mundanely good hetus to bring about pleasurable consequences, such as re-birth in heaven. Such resultants, however, are themselves neither meritorious nor demeritorious, but are indeterminate. Hence they belong to an entirely different category from their causes. For this reason Vipāka hetu is generally called Heterogeneous cause,
1 A.K. 6-10b.
2 A.K. 6-11b. 
inasmuch as its effects are different both as regards time of maturity and nature from the cause.

The dharmas which act as Vipāka hetu may belong either to the category of the material (Rüpa), mental (Citta or Caitasika), or miscellaneous (Viprayukta), but such dharmas must belong to the category of positively demeritorious or Sāsrava meritorious. Neither of the two classes of neutral (obstructing and non-obstructing) nor Anāsrava meritorious can act as a Vipāka hetu. Neutral is excluded, according to the Abhidharma Kośa, because it is like a mouldy seed, and Anāsrava kuśala because, being uninfluenced by the karmaic fructification of the passions, it is like a good seed which does not come to fruition because it has not been fructified by water. For this reason it cannot bring about re-birth.

The Buddhists, and more particularly the Sarvāstivādins, believe that there might be various linds of numerical relations between the Vipāka hetu and its effects. This cause was frequently likened to a seed, and just as some seeds result in a small quantity of fruit, and others in a great deal, so might certain Vipāka hetus have a great many results and others but few. In this way a single action in one life may have effects in several lives, but aggregate actions in several lives could not form a single group resulting in a single effect in one life. A single thought-moment may give rise to several subsequent thought-moments, but several thought-moments could not give rise to a single thought-moment.

On the other hand, a number of different dharmas co-existing at any one specified time within the limits of one single human or other personality might form a group acting as a single Vipāka hetu resulting in some one (or more) effect. These causal dharmas might or might not be members of a single skandha. (Numerical details of possible combinations of dharmas, skandhas, etc., as causes and effects, will be found A.K. 6-12b ff.)

From the foregoing remarks it will be seen that the hetus readily fall into a two-fold classification, one made according 
to the dharmas which serve as causes, and the other according to the temporal relationships between the causes and their effects. This may be illustrated in the following way :-

1. Types of causality where all dharmas may act as causes.

2. Types of causality where only mental dharmas can act as causes.

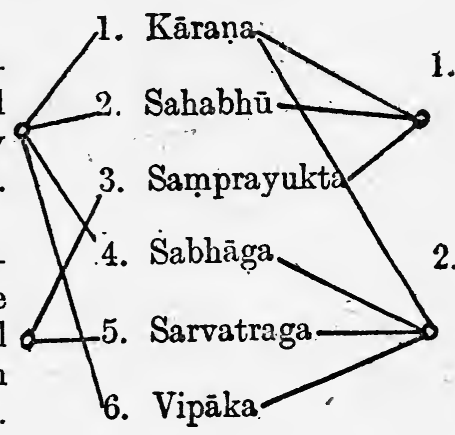

1. Types of causality where cause and effect are simultaneous.

2. Types of causality where effects arise only after causes dis. appear.

Owing to the limited space at our disposal, it is impossible to deal at length with the Northern Buddhists' theory of causality and its relation to other causal theories, but it is important to notice how the non-substantialist position of Buddhism affected its theory of causality, contrasting it sharply with the causal theories of the substantialists. These latter philosophers, whether Occidental, like Aristotle, or Oriental, as in the case of the Vaiśeșika, Jain, or Sāṃkhya systems, believed in a permanent substance behind attributes and modes, and as no phenomenon could exist without this substance behind it, this substance could be said to be the constant co-existing cause. In contrast to this, the Buddhists postulated but two types of causality, in which cause and effect were simultaneous, and in neither case were any of the causes permanent; in fact, both cause and effect were of but momentary duration. In the other three cases of direct causality the effect could only come into being after the cause itself had disappeared. (Cf. on this point the A.K. argument with the Sāmkhyas, A.K. 11-2b.) 


\section{The Five Phalas ${ }^{1}$}

As the result of the action and interaction of the four pratyayas and the six hetus, the universe comes into being. From the causal point of view every existing object can be said to be one of five kinds of effects. Every single object can come under more than one of these categories, since every phenomenon is the result of more than one cause. The five types of effects are :--

1. Adhipati phala, or aggregate effect.

2. Purușakāra phala, or simultaneous effect.

3. Nisyanda phala, or uniformly continuous effect.

4. Vipāka phala, or heterogeneous effect.

5. Visamyoga phala, or emancipated effect.

1. Adhipati phala is a phenomenon regarded as the single effect of the general causal influence exerted by every dharma in the universe. Consequently, it is the effect of Kärana hetu, and is thereby, at the same time, the result of Allambana, Samanantara, and Adhipati pratyayas (in those circumstances where such pratyayas apply), since these are but subdivisions of Kāraṇa hetu. Since such a resultant dharma is the effect of the activity of a large number of different causal dharmas, it is frequently called the aggregate effect. Since all things are influenced by all other things, it follows that all phenomena may be regarded as Adhipati phala, but the term is specifically applied to those phenomena whose origination cannot be accounted for by any other of the five hetu. This is a very important category, however, for the external universe is regarded as the Adhipati phala of the aggregate actions of the sentient beings of former times. (A.K. 6-19b.)

2. Purusakāra phala literally means the effect of human actions. In its first sense it is taken metaphorically as meaning effects which are simultaneous with their causes, as when a man hammers out a horseshoe the shape assumed by the horseshoe is simultaneous with the energy exerted by the

1 For Sarv. A.K. 6-14 seq. ; N.A. 17-1a. For Yog. V.M.S., f. 8, p. 346. 
man. In this sense Purușakāra phala is considered the effect of the causal influences of Sahabhu hetu and Samprayukta hetu, where, however, not only is the cause and effect simultaneous, but the various units are so related that each may be said to be both the cause and effect of another.

In addition to this specialized application of Purușakāra phala, however, it is also used in the more literal sense of the effect brought about by sentient agency, or when one thing arises as the direct result of the action of another, either immediately or in quick succession, or even after the lapse of some time, as when the present harvest is regarded as the Purușakāra phala of the sowing of the seed by the farmer in the previous year. In this way, when the result of a certain kind of mental activity leads to the arising of a higher stage of consciousness, it may be regarded as the Purușakāra phala of the action of the preceding mental activity. Used in this sense, Purușakāra phala is the result not only of Sahabhū and Samprayukta hetu, but also of the activity of Sabhāga, Sarvatraga, and Vipāka hetus, in addition, of course, to Kāraṇa hetu.

Purușakāra hetu is contrasted with Adhipati hetu by the directness or indirectness of the relationship between the causing agents and the result. The general condition of the material world is Adhipati phala, but any constructed material object produced by the action of a man $A$ is a Purușakāa phala as regards $A$, but an Adhipati phala as regards every other person (A.K. 6-21).

3. Nisyanda phala, or successive effect, is when one moment in an organism is regarded as the effect of the preceding moments; at least, when the subsequent moments are regarded as being of the same nature as their antecedents. Thus, e.g., owing to the activity of Vipāka hetu or some other cause, $A$ may be followed by some group of a quite different nature. In this case the new group would not be called a Nisyanda phala, but in almost all new groups there are certain dharmas which are effected as the result of the reproductive powers 


\section{MANUAL OF BUDDHIST PHILOSOPHY}

of earlier homogeneous dharmas, and will thus come under our present category.

This type of effect includes the results of the activity of both Sabhāga and Sarvatraga hetus. We have already seen the differences between these two causes, the latter being confined to those defiling influences which exert a productive influence over all non-meritorious Caitasikas of its own sphere, while the former merely represent the natural tendency of the Caitasikas of each sphere, nature, and section to reproduce itself. Hence certain groups of mentals may be the result of one or the other, some may be the results of both, and some may be the result of neither. (See the list A.K. $6-20 b$.)

4. Vipāka phala, or heterogeneous effect, is obviously the result of the activity of Vipāka hetu. Where the effect is neither simultaneous with, nor immediately consequent upon, nor of the same nature as the cause, and yet is the result of personal activity, it is called Vipāka phala. Thus, at the moment of re-birth in one of the heavens or hells, the new Nāma Rūpa is called Vipāka phala. Consequently, the type of causality represented by Vipāka hetu and Vipāka phala is very broad. Nevertheless, it is limited in the following way. Vipāka hetu must be either definitely meritorious or definitely demeritorious, as we have already seen. Vipāka phala, on the other hand, can only belong to the category of unobstructing neutral. Being purely a result, it can belong to neither definite moral category. ${ }^{1}$ Again, Vipāka phala only applies to sentient beings. The whole state of the external world is said to be the result of karma. Why is it not included in the catigory of Vipāka phala? Because it is the aggregate result of the action of all sentient beings, and is thus Adhipati phala, while Vipāka phala must be the individual result of individual action. (A.K. 6-20a.)

1 This was a bone of contention between the Sarv. and the Sautrāntikas. For discussion and counter-discussion cf. A.K. 6-14a to 6-19b. 
5. Visamyoga phala is equivalent to Nirvāna. Literally, it means the freedom from bondage or emancipation from the wheel of birth and death. This is the result of certain kinds of mental and moral training or karma, and hence is regarded as a special class of Vipāka phala, but the transcendental nature of the category rendered it necessary for the Buddhists to give it a separate place in their list of effects.

A careful examination of what has preceded gives us the following table of relationships between the five phalas on the one hand and the four pratyayas and the six hetus on the other:-

The 6 Hetus.

The 5 Phalas.

1. Kärana

2. Sahabhū

3. Samprayukta

4. Sabhäga

5. Sarvatraga

6. Vipäka-

The 4 Prutyayas.

1. Hetu

2. Samanantara

3. Ālambana

4. Adhipati
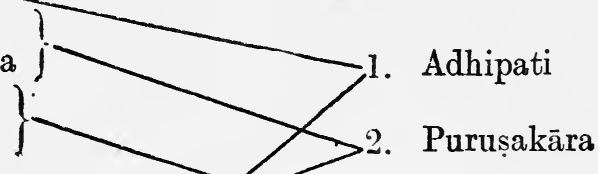

In this connexion one or two additional points must be borne in mind. First is the fact that some schools postulated four additional effects. These were (1) supported effect, as in the case of the circle of water, which, according to Buddhist cosmology, was supported by the circle of air. In like manner all vegetation is supported by the earth. (2) Acquired effect, as when the mind by means of meditation acquires wisdom. (3) Harmonious effect, as in the case of the Cakșur-vijñanna, which is the harmonized effect of the Caksur-indriya. Trained effect, as when the nature of the mind is changed by means of Dhyāna. These four classes of effect, however, Vasubandhu (A.K. 6-27b) considers but variations of divisions of Purușakāra and Adhipati phalas. 


\section{MANUAL OF BUDDHIST PHILOSOPHY}

Owing to the predominately psychological tone of all Buddhist speculation, more emphasis has been laid upon the causal relationships between the various types of mental dharmas than upon the material dharmas. It may, therefore, be of interest to see what the Sarvāstivādins had to say concerning the causal forces exerted by one type of matter upon another. This problem, of course, lay outside the field of the Yogācārins. This relationship may be discussed in five ways :

1. The causal influence of one Mahābhūta upon another. This is said to be of two kinds, Sahabhū and Sabhāga. The first is the relation of the four Mahābhūtas on one another at any one given moment and within one special organism. The latter is the way in which the Mahābhütas reproduce themselves in later moments. ${ }^{1}$

2. The causal influence exerted by the Mahābhūtas upon the Bhautikas. We have already seen that there is a five-fold relationship between the fundamental and derivative forms of matter. The Abhidharma Kośa tells us, however, that these five kinds of dependence are but subdivisions of the influence of Kāraṇa hetu upon Adhipati phala.

3. The influence of Bhautikas over Bhautikas. This comprises Sabhāga, Sahabhū, and Vipāka hetus, in addition, of course, to Kārana hetu. Sahabhū hetu refers only to the physical and vocal actions (which are ranked as physical Bhautikas), which in virtue of their function as mental associates rank as Sahabhū hetus. In their purely physical aspect they cannot exercise this function. Sabhāga hetu is the influence exercised by the previous groups of Bhautikas upon their successors. Vipāka hetu refers to the karmaic energy engendered by groups of Bhautikas, whether meritorious or demeritorious, which will result in the neutral Vipāka phala (e.g. Cakșur-indriya) of the future life.

4. The influence of the Bhautikas upon the Mahābhūtas. This is but of one kind. The karma engendered by the

1 A.K. 7-8a seq. 
Bhautikas may serve as Vipāka hetus, bringing about the formation of new groups of Mahābhütas.

5. In addition, the Sarvāstivādins, and to a lesser extent the Yogācārins, have long and very elaborate tables showing the causal influence exerted by various groups of mentals upon one another. ${ }^{1}$ The compass of our present undertaking, however, will not permit us to repeat them here, as in any case enough has been said to show the general nature of such relationships.

1 See especially last portion of $f .7$ of A.K. 





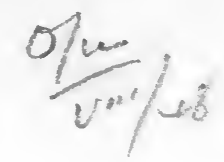

B

123

13

V.I

McGovern, William Mont-omery

A manual of Buddhist philosophy

\section{PLEASE DO NOT REMOVE}

CARDS OR SLIPS FROM THIS POCKET

\section{UNIVERSITY OF TORONTO LIBRARY}




\section{(1)}

